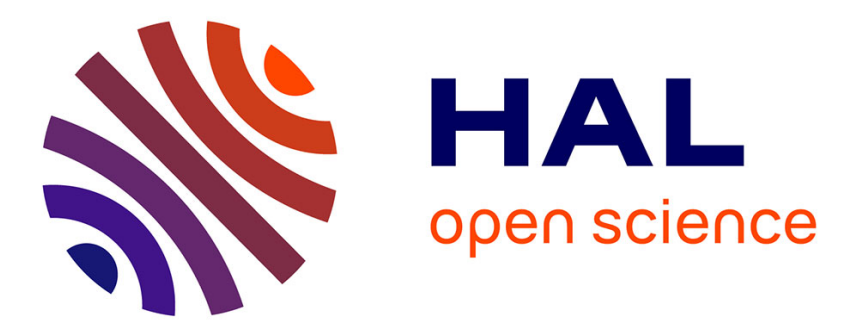

\title{
Mengintegrasikan Adaptasi ke dalam REDD+: Dampak Potensial dan Rentabilitas Sosial di Setulang, Kabupaten Malinau, Indonesia
}

Emilia Pramova, Bruno Locatelli, Andreas Mench, Edy Marbyanto, Karlina Kartika, Hangga Prihatmaja

\section{To cite this version:}

Emilia Pramova, Bruno Locatelli, Andreas Mench, Edy Marbyanto, Karlina Kartika, et al.. Mengintegrasikan Adaptasi ke dalam REDD+: Dampak Potensial dan Rentabilitas Sosial di Setulang, Kabupaten Malinau, Indonesia. 2013, pp.78. cirad-00925942

\section{HAL Id: cirad-00925942 http://hal.cirad.fr/cirad-00925942}

Submitted on 8 Jan 2014

HAL is a multi-disciplinary open access archive for the deposit and dissemination of scientific research documents, whether they are published or not. The documents may come from teaching and research institutions in France or abroad, or from public or private research centers.
L'archive ouverte pluridisciplinaire HAL, est destinée au dépôt et à la diffusion de documents scientifiques de niveau recherche, publiés ou non, émanant des établissements d'enseignement et de recherche français ou étrangers, des laboratoires publics ou privés. 
M A K A L A H K ER J A

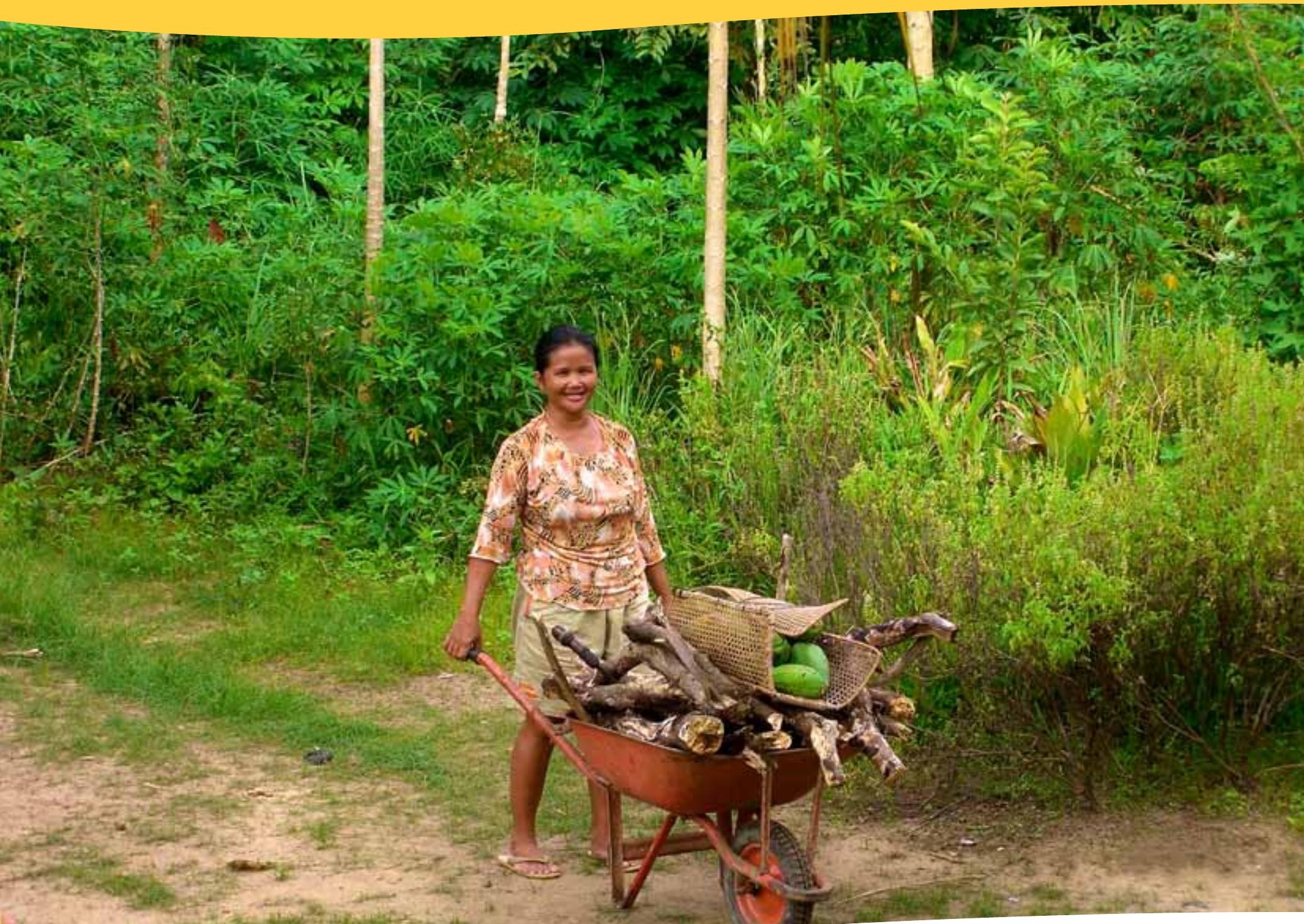

\section{Mengintegrasikan Adaptasi ke dalam REDD+}

\section{Dampak Potensial dan Rentabilitas Sosial di Setulang, Kabupaten Malinau, Indonesia}

Emilia Pramova

Bruno Locatelli

Andreas Mench

Edy Marbyanto

Karlina Kartika

Hangga Prihatmaja

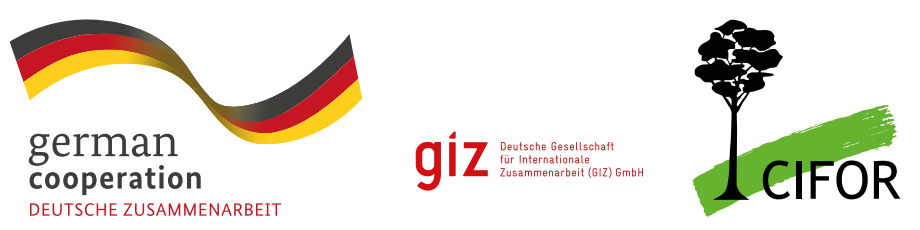





\section{Mengintegrasikan Adaptasi ke dalam REDD+ Dampak Potensial dan Rentabilitas Sosial di Setulang, Kabupaten Malinau, Indonesia}

Emilia Pramova

Bruno Locatelli

Andreas Mench

Edy Marbyanto

Karlina Kartika

Hangga Prihatmaja 
Makalah Kerja 114

(c) 2013 Center for International Forestry Research

Pramova, E., Locatelli, B., Mench, A., Marbyanto, E., Kartika, K. dan Prihatmaja, H. 2013. Mengintegrasikan Adaptasi ke dalam REDD+: Dampak Potensial dan Rentabilitas Sosial di Setulang, Kabupaten Malinau, Indonesia. Makalah Kerja 114. Bogor, Indonesia: CIFOR.

Foto sampul oleh Nining Liswanti/CIFOR

Malinau, Kalimantan Timur

Studi ini dilaksanakan oleh CIFOR bekerja sama dengan Deutsche Gesellschaft für Internationale Zusammenarbeit (GIZ GmbH), dengan hibah dari Kementerian Federal untuk Kerja sama Ekonomi dan Pembangunan (BMZ) Jerman.

CIFOR

Jl. CIFOR, Situ Gede

Bogor Barat 16115

Indonesia

$\mathrm{T}+62(251) 8622-622$

$\mathrm{F}+62(251) 8622-100$

E cifor@cgiar.org

\section{cifor.org}

Sejumlah pandangan yang disajikan dalam buku ini berasal dari para penulisnya. Mereka tidak serta merta mencerminkan pandangan CIFOR, para penyunting, institusi para penulis, pendukung dana maupun para pengulas. 


\title{
Daftar isi
}

\author{
Daftar Singkatan
}

Ucapan Terima Kasih

vi

Tentang FORCLIME vii

Ringkasan Eksekutif viii

1 Sasaran dan Kegiatan 1

1.1 Tujuan dan Sasaran Utama $\quad 1$

1.2 Kerangka Kerja Rentabilitas Sosial 1

2 Lokasi dan Konteks Studi $\quad 3$

2.1 Lokasi Studi 3

2.2 Konteks di Malinau dan Setulang $\quad 4$

3 Metode $\quad 6$

3.1 Lokakarya Masyarakat 6

3.2 Wawancara dengan Pemangku Kepentingan di Organisasi Tingkat Kabupaten $\quad 7$

3.3 Analisis Perubahan Iklim dan Kerentanan $\quad 8$

4 Pandangan para Pemangku Kepentingan 11

4.1 Anggota Masyarakat: Persepsi atas Sumber Daya, Tantangan dan Strategi Penanggulangan 11

4.2 Wawancara Tingkat Kabupaten: Persepsi atas Tantangan dan Bencana Utama di Malinau $\begin{array}{ll}\text { dan Setulang } & 15\end{array}$

5 Analisis Iklim dan Kerentanan $\quad 20$

$\begin{array}{ll}5.1 \text { Paparan } & 20\end{array}$

5.2 Sensitivitas 24

5.3 Kapasitas Adaptif 29

$\begin{array}{lll}5.4 \text { Kebijakan Adaptasi } & 31\end{array}$

6 Intervensi Adaptasi Berbasis Masyarakat 33

6.1 Prioritas Masyarakat untuk Masa Depan 33

6.2 Intervensi-intervensi Terpilih 34

7 Kaitan dengan REDD+ $\quad 42$

7.1 Adaptasi dan Mitigasi $\quad 42$

7.2 Skenario dengan Strategi Penanggulangan saat ini dan Eksploitasi yang Tidak Berkelanjutan 42

7.3 Skenario dengan Adaptasi dan Pengelolaan yang Berkelanjutan 44

8 Analisis Biaya-Manfaat dan Rentabilitas Sosial 46

8.1 Analisis Biaya-Manfaat $\quad 46$

$\begin{array}{ll}\text { 8.2 Peta dampak keluaran sosial dari suatu investasi } & 48\end{array}$

9 Daftar Pustaka $\quad 55$

$\begin{array}{ll}\text { Lampiran } & 61\end{array}$

1 Jadwal kegiatan $\quad 61$

2 Panduan untuk wawancara semi terstruktur dengan pemangku kepentingan kabupaten 62 


\section{Daftar Tabel dan gambar}

\section{Tabel}

1 Aset dan sumber daya dalam urutan prioritas dan kondisi saat ini

(berdasarkan kelompok jender)

2 Kelembagaan di desa

3 Tantangan/bahaya dan strategi penanggulangan: respon masyarakat

4 Tantangan/bahaya dan strategi penanggulangan: responden tingkat kabupaten

5 Suhu kritis untuk pengembangan padi pada tahapan pertumbuhan yang berbeda

6 Strategi prioritas berbasiskan aset masyarakat

7 Hasil panen dan harga pohon buah-buahan

8 Biaya dan manfaat wanatani karet, menurut anggota masyarakat dan pemangku kepentingan tingkat kabupaten

9 Biaya dan manfaat penjualan kerajinan tangan rotan, menurut anggota masyarakat dan pemangku kepentingan tingkat kabupaten

\section{Gambar}

1 Contoh teori perubahan

2 Peta hutan Tane' Olen dan Desa Setulang

3 Kegiatan lokakarya: Menempatkan aset dan tantangan yang penting ke dalam klaster tematis

4 Kerentanan sebagai sebuah fungsi dari paparan, sensitivitas dan kapasitas adaptif

5 Stasiun cuaca di sekitar Malinau

8

6 Rumah adat di Setulang, tempat pertemuan desa diselenggarakan

7 Menyusuri Sungai Malinau 15

8 Iklim rerata di Malinau 20

9 Variabilitas curah hujan tahunan di Malinau (1960-2010) 21

10 Variabilitas suhu tahunan di Malinau (1960-2010) 21

11 Curah hujan tahunan di Malinau pada 2020, 2050 dan 2080, berdasarkan 16 skenario iklim

12 Prakiraan curah hujan bulanan di Malinau untuk 2080

13 Suhu rerata di Malinau pada 2020, 2050 dan 2080, berdasarkan 16 skenario iklim 23

14 Hubungan antara suhu dan pertumbuhan pisang 26

15 Keranjang yang dibuat oleh perempuan Setulang 38 


\section{Daftar Singkatan}

Bappeda

Bappenas

BMZ

CBA

CIFOR

$\mathrm{dbh}$

DNPI

DRC

ENSO

FORCLIME

GCM

Gerdema

GIZ

ICRAF

IPCC

NTFP

PKK

REDD+

SROI

WWF
Badan Perencanaan Pembangunan Daerah

Badan Perencanaan Pembangunan Nasional

Bundesministerium für wirtschaftliche Zusammenarbeit und Entwicklung (Kementerian Federal untuk Kerja sama Ekonomi dan Pembangunan)

cost-benefit analysis (analisa biaya-manfaat)

Center for International Forestry Research (Pusat Penelitian Kehutanan Internasional)

diameter at breast height (diameter setinggi dada)

Dewan Nasional Perubahan Iklim

dry rubber content (kandungan kering karet)

El Niño-Southern Oscillation (El Nino Osilasi Selatan)

Forests and Climate Change Programme (Program Hutan dan Perubahan Iklim)

general circulation model (model sirkulasi umum)

Gerakan Desa Membangun

Deutsche Gesellschaft für Internationale Zusammenarbeit (Masyarakat Jerman untuk Kerja sama Internasional)

World Agroforestry Centre (Pusat Penelitian Wanatani Dunia)

Intergovernmental Panel on Climate Change (Panel Antar Pemerintah untuk Perubahan Iklim)

non-timber forest product (hasil hutan bukan kayu)

Pemberdayaan dan Kesejahteraan Keluarga

Reducing emissions from deforestation and forest degradation and enhancing forest carbon stocks (Pengurangan emisi dari deforestasi dan degradasi hutan dan peningkatan cadangan karbon)

social return on investment (rentabilitas sosial)

World Wildlife Fund 


\section{Ucapan Terima Kasih}

Studi ini terlaksana atas kontribusi finansial dari Kementerian Federal Jerman untuk Kerja sama Ekonomi dan Pembangunan (BMZ) dan dukungan teknis serta logistik dari Masyarakat Jerman untuk Kerja sama Internasional (GIZ). Kami secara khusus berterima kasih pada tim GIZ FORCLIME yang berbasis di Kalimantan, dan khususnya Mr. Andreas Mench, Ms. Karlina Kartika, Bapak Edy Marbyanto, Bapak Budi Susanto, Bapak Alie Mustofa dan Mr. Timo Beiermann untuk bantuan mereka yang luar biasa dalam mengorganisasikan dan menyelenggarakan lokakarya masyarakat dan untuk memfasilitasi kontak kami dengan sejumlah organisasi dan para pemangku kepentingan di tingkat kabupaten. Kami juga berterima kasih telah dikenalkan dengan Malinau dan sekitarnya serta memastikan bahwa masa tinggal kami di wilayah ini tidak bermasalah, produktif dan menyenangkan.

Kami juga berterima kasih kepada masyarakat Setulang yang telah berbagi pengetahuan mereka yang sangat banyak dengan kami, juga untuk antusiasme, kerja keras dan semangat yang hebat selama lokakarya yang panjang. Kami berterima kasih untuk keramahtamahan mereka dan sajian lezat serta tarian Kenyah Dayak yang indah yang ditampilkan pada malam pertama kami di desa.

Terakhir namun tidak kalah pentingnya, kami ingin menyampaikan terima kasih khusus pada para perwakilan organisasi dan dinas pemerintah di kabupaten, yang telah memberikan waktu dari jadwal mereka yang padat untuk berdiskusi dengan kami: Dr. Yansen TP MSi (Bupati Malinau); Bapak Tomi Frent Lukas, Bapak Abdul Majid dan Bapak Apriansyah (Dinas Kehutanan); Ibu Endang Wertiningsih (Dinas Pertanian); Bapak Ajang Kahang (Dinas Pemberdayaan Masyarakat); Bapak Dhani Subroto (Bappeda); Bapak Yance Nikolas (Dinas Perkebunan); Bapak Farhani (Taman Nasional Kayan Mentarang); Bapak Abdul Fattah (Dinas Lingkungan Hidup); Bapak Ary (Dinas Perindustrian dan Kerja sama); dan Bapak Deden (World Wildlife Fund). 


\section{Tentang FORCLIME}

Program Hutan dan Perubahan Iklim (Forests and Climate Change Programme/FORCLIME) mendukung pemerintah Indonesia dalam usaha memitigasi dampak perubahan iklim melalui reformasi sektor kehutanan, peningkatan kapasitas dan implementasi praktik-praktik pengelolaan terbaik untuk pengelolaan hutan lestari dan konservasi keanekaragaman hayati. Dukungan untuk sejumlah kegiatan percontohan dilaksanakan di beberapa kabupaten terpilih di Kalimantan untuk mengurangi emisi dari deforestasi dan degradasi hutan (kegiatan-kegiatan REDD). FORCLIME didanai oleh Kementerian Federal Jerman untuk Kerja sama Ekonomi dan Pembangunan dan dilaksanakan oleh Kerja sama Internasional Jerman dan Bank Pembangunan Jerman, dengan Kementerian Kehutanan Indonesia sebagai Instansi Pelaksana Program.
Tujuan umum program ini adalah untuk mengurangi emisi gas rumah kaca dari sektor kehutanan dan pada saat yang sama meningkatkan taraf hidup masyarakat miskin di pedalaman Indonesia. Untuk mencapai tujuan ini, tim Program membantu Pemerintah Indonesia dalam merancang dan menerapkan reformasi hukum, kebijakan dan kelembagaan untuk konservasi dan pengelolaan hutan yang lestari, pada tingkat lokal, provinsi dan nasional. Dukungan untuk sejumlah kegiatan percontohan REDD merupakan kunci program, memberikan pengalaman bagi para pengambil keputusan tentang bagaimana REDD dapat diterapkan "di lapangan".

Untuk informasi lebih lanjut, silakan kunjungi: www.forclime.org 


\section{Ringkasan Eksekutif}

Intervensi pengurangan emisi dari deforestasi dan degradasi hutan serta peningkatan cadangan karbon hutan (REDD+) dapat membantu masyarakat dan hutan untuk beradaptasi dengan perubahan iklim melalui melestarikan dan menguatkan jasa keanekaragaman hayati dan ekosistem hutan. Namun, sejumlah tindakan adaptasi tambahan mungkin diperlukan, seperti perlindungan terhadap pertanian dan penghidupan serta pengembangan sejumlah strategi pengelolaan kebakaran. Berbagai tindakan ini dapat mendukung keberlanjutan intervensi REDD+ dan sifat permanen cadangan karbon dengan mencegah kegiatan yang merugikan dan memicu deforestasi serta dengan membatasi atau menghindari kerusakan ekosistem dari kejadian iklim ekstrem.

Untuk merancang intervensi adaptasi berbasis masyarakat dan mengukur keluaran potensialnya di wilayah proyek REDD+, anggota masyarakat di Desa Setulang, Kabupaten Malinau, Kalimantan Timur (sekarang Kalimantan Utara) dilibatkan dalam suatu proses dari bawah ke atas, yang berfokus pada para pemangku kepentingan. Sebuah kerangka kerja rentabilitas sosial diterapkan dalam proses ini. Para perwakilan masyarakat mendiskusikan berbagai tantangan iklim maupun non iklim dan keefektifan strategi mereka saat ini dalam menghadapinya. Intervensi adaptasi kemudian dikembangkan dan direncanakan, menggunakan latihan-latihan dengan visi ke depan.

Berbagai tantangan, strategi untuk mengatasi dan intervensi adaptasi juga dibahas dengan para pemangku kepentingan dari organisasi tingkat kabupaten yang bersangkutan (misalnya, dinasdinas pemerintah setempat) melalui wawancara semi terstruktur secara perorangan. Prakiraan skenario masa depan, sensitivitas sumber daya utama dan kapasitas adaptif juga didiskusikan. Pendekatan ini menghasilkan pemahaman yang menyeluruh tentang biaya, manfaat, peluang dan tantangan yang berkaitan dengan implementasi sejumlah strategi adaptasi yang terpilih, tidak hanya untuk wilayah yang ditargetkan, namun juga secara lebih luas di wilayah kabupaten.
Setulang memiliki lokasi yang relatif menguntungkan secara geografis, dekat dengan hutan maupun Kota Malinau. Desa ini memiliki berbagai aset dan sumber daya yang mendukung kemampuan adaptif penduduknya, seperti modal sosial yang kuat, kesatuan dan kebersamaan, sumber daya hutan yang relatif tidak terdegradasi, keahlian dan pengetahuan dalam pengelolaan hutan, serta kelembagaan desa yang kuat.

Namun demikian, kesenjangan kapasitas adaptif terlihat dari kurangnya infrastruktur pertanian dan informasi (misalnya, ketiadaan infrastruktur irigasi dan jaringan telekomunikasi). Selain itu, hak atas wilayah hutan yang dilindungi, yang dikenal sebagai Tane' Olen juga tidak jelas, dan konflik perbatasan dengan desa tetangga juga kerap muncul.

Faktor lain yang mengurangi kapasitas adaptif masyarakat adalah ketidakpastian akses ke sumber daya alam, rendahnya keragaman kegiatan di dalam dan di luar pertanian, serta kurangnya akses ke pendidikan dan perawatan kesehatan.

Tantangan lain yang diidentifikasi oleh anggota masyarakat adalah penyalahgunaan obat oleh kaum muda, penyalahgunaan kekuasaan, pencemaran sungai akibat aktivitas pertambangan dan pengelolaan sampah yang tidak memadai, penyakit, kekeringan dan pembalakan liar, serta tren anak muda yang bermigrasi ke daerah perkotaan.

Para pemangku kepentingan dari instansi pemerintah dan LSM di tingkat kabupaten memandang bahwa sejumlah bencana terkait iklim seperti banjir, kekeringan dan pergeseran musim, sebagai masalah utama bagi Malinau. Model proyeksi menunjukkan bahwa bencana iklim di Malinau sangat mungkin terjadi lebih sering dan skala besar. Hutan dan produksi pertanian, khususnya tanaman seperti padi, pisang, ubi kayu dan ubi jalar rentan terhadap variabilitas iklim, serta perubahan iklim yang ekstrem dan berjangka panjang.

Anggota masyarakat merasa bahwa strategi mereka untuk menghadapi tantangan belum memunculkan 
solusi jangka panjang dan berkelanjutan. Sebuah strategi adaptasi berjangka lebih panjang yang mereka terapkan secara proaktif adalah konservasi yang direncanakan atas hutan sehingga hutan dapat menjadi 'bank makanan' pada saat terjadi kelangkaan. Penduduk desa menyatakan bahwa diversifikasi mata pencaharian yang lebih luas dan kapasitas untuk menyimpan kelebihan pangan dan uang tunai akan membuat mereka merasa lebih aman.

Selama lokakarya, anggota masyarakat Setulang memunculkan dan memilih dua intervensi adaptasi yang diyakini dapat membawa manfaat dan dapat menggunakan sumber daya yang ada sebagai modal: (1) wanatani karet dan (2) pembuatan dan penjualan kerajinan tangan rotan.

Manfaat yang dirasakan dari wanatani karet adalah diversifikasi mata pencaharian, produksi panen yang menghasilkan uang tunai dan meningkatkan ketahanan terhadap bencana iklim. Alasannya adalah karena sistem wanatani karet dapat bertahan lebih baik dari tekanan banjir dan kekeringan dibandingkan komoditas lain seperti beras. Wanatani karet diharapkan dapat merehabilitasi lahan terdegradasi. Selain itu karena perawatannya tidak terlalu sulit maka petani masih dapat melakukan kegiatan pertanian atau penghidupan yang lain.

Biaya operasional terkait wanatani karet juga dianggap rendah. Biaya utama adalah bahan-bahan seperti bibit dan tenaga kerja, pemanfaatan lahan dan pelatihan terkait teknis. Namun kebutuhan untuk pelatihan merupakan hambatan karena kurangnya keahlian di bidang ini di kalangan instansi pemerintah setempat.

Gagasan di balik penjualan dan pembuatan kerajinan tangan rotan adalah untuk memanfaatkan tradisi kerajinan di desa ini. Walaupun kaum perempuan membuat kerajinan tangan terutama untuk kebutuhan pribadi atau domestik, menjual kerajinan tangan dapat menghasilkan pendapatan tambahan, khususnya bagi perempuan ketika hasil panen yang dijual tidak memadai. Selain itu, kerajinan tangan dapat dibuat oleh kaum perempuan di saat luang atau mereka yang tidak bekerja di lapangan. Pasar yang potensial adalah desa-desa di sekitarnya, turis dan ajang pameran.

Biaya untuk bahan mentahnya (rotan dan pewarna alami) juga murah, dan umumnya tersedia secara cuma-cuma sebagai barang milik bersama dari hutan Tane' Olen, atau dapat dibeli dengan harga murah dari tetangga atau desa-desa lain. Termasuk dalam biaya lainnya adalah transportasi dan distribusi serta kebutuhan pelatihan untuk para calon pengusaha dalam merancang dan memasarkan produk.

Prediksi perubahan iklim tampaknya tidak memengaruhi strategi penjualan kerajinan tangan, karena sumber bahan bakunya yaitu Tane' Olen, relatif tidak terganggu dan merupakan hutan yang dikelola secara berkelanjutan. Namun demikian, untuk wanatani karet, batasan tertentu untuk iklim dan biofisik perlu dipantau untuk memastikan bahwa petani telah bersiap untuk mengambil tindakan-tindakan yang diperlukan untuk menghindari kerugian panen dan kerusakan. Produktivitas jenis pohon buah-buahan, seperti durian dan rambutan juga dapat dipengaruhi oleh suhu dan curah hujan yang ekstrem.

Selain dampak langsung dari proyek-proyek adaptasi yang disarankan, intervensi juga dapat memiliki keluaran tidak langsung bagi REDD+. Manfaat yang sinergis dapat dicapai dari implementasi bersama REDD+ dan sejumlah strategi adaptasi untuk mengoptimalkan dampak positif secara keseluruhan. Sebagai contoh, jaringan kerja dan pendanaan REDD+ dapat dimanfaatkan untuk mewujudkan informasi iklim yang tepat waktu dan relevan untuk adaptasi, baik untuk masyarakat petani maupun hutan. Informasi semacam ini dapat diintegrasikan ke dalam sebuah model pengelolaan yang adaptif, yang hasil intervensinya dipantau, dievaluasi, dan disesuaikan kembali secara terus-menerus sesuai dengan perubahan situasi dan kebutuhan (misalnya, perubahan pemicu deforestasi dan degradasi dan perubahan tekanan iklim). Pengelolaan adaptif harus menjadi landasan bagi semua intervensi dalam kondisi ketidakpastian. 



\section{Sasaran dan Kegiatan}

\subsection{Tujuan dan Sasaran Utama}

Studi Mengintegrasikan Adaptasi ke dalam ProyekProyek REDD+: Dampak Potensial dan Rentabilitas Sosial (Social Return on Investment) dilaksanakan oleh Center for International Forestry Research(CIFOR) di dua lokasi percontohan, satu di Indonesa dan lainnya di Filipina. Studi ini didanai oleh Deutsche Gesellschaft für Internationale Zusammenarbeit (GIZ) dengan hibah dari Kementerian Federal untuk Kerja sama Pembangunan (BMZ).

Tujuan utama studi ini adalah untuk menemukan kemungkinan dampak mengintegrasikan intervensi adaptasi berbasis masyarakat ke dalam proyek-proyek percontohan pengurangan emisi dari deforestasi dan degradasi hutan serta peningkatan cadangan karbon hutan (REDD+) dengan mengukur potensi rentabilitas sosialnya. Masyarakat yang bergantung pada hutan serta para pengambil keputusan lokal maupun nasional dan para praktisi yang memengaruhi atau dipengaruhi oleh kegiatankegiatan percontohan REDD+ merupakan kelompok target utama.

Secara lebih spesifik, sasaran utama yang ingin dicapai adalah sebagai berikut:

1. Mengukur kerentanan terhadap variabilitas dan perubahan iklim dengan mengunakan analisis desktop dan metode partisipatif, serta merancang intervensi adaptasi dengan para pemangku kepentingan pada berbagai tingkatan.

2. Menganalisis potensi rentabilitas sosial, ekonomi dan lingkungan hidup atas intervensi adaptasi yang terpilih berdasarkan persepsi para pemangku kepentingan.

3. Menentukan dampak dan nilai keseluruhan yang berpotensi terwujud apabila intervensi mencapai hasil yang dimaksudkan, khususnya jika dibandingkan dengan skenario tanpa aksi (tanpa intervensi adaptasi).

Studi ini juga bermaksud untuk mengevaluasi dan memperbaiki kerangka kerja Social Rentability of Investment (SROI) untuk perencanaan adaptasi dan menghasilkan sebuah buku panduan untuk para praktisi dalam rangka replikasi kegiatan-kegiatan ini di lokasi lain.

\subsection{Kerangka Kerja Rentabilitas Sosial}

SROI merupakan kerangka kerja yang mengacu pada prinsip-prinsip analisis biaya-manfaat ekonomi, penilaian dampak dan perhitungan sosial untuk memahami dan mengelola nilai hasil-hasil sosial, ekonomi dan lingkungan atas suatu kegiatan atau organisasi. SROI dirintis oleh Roberts Enterprise Development Fund pada awal 2000 dan telah berkembang sejak saat itu. Studi ini didasarkan pada versi kerangka kerja dalam $A$ Guide to Social Return on Investment (Nicholls dkk. 2012), yang direkomendasikan oleh Pemerintah Kerajaan Inggris untuk digunakan dalam mengevaluasi berbagai kegiatan dan organisasi nirlaba serta usaha sosial.

Proses SROI mencakup meninjau sejumlah masukan, keluaran, hasil dan dampak suatu intervensi atau organisasi di dalam sebuah "peta dampak". Berbagai hasil sosial, lingkungan dan ekonomi ditentukan oleh para pemangku kepentingan yang merasakannya sendiri. Suatu nilai moneter yang memungkinkan ditetapkan atas hasil berdasarkan harga pasar yang berlaku untuk barang-barang komersial dan proksi finansial untuk hasil-hasil yang tidak terlihat atau tidak dapat dipasarkan (misalnya, lebih banyak waktu luang bagi perempuan).

Partisipasi dan analisis pemangku kepentingan merupakan inti pendekatan ini, karena mereka sendiri yang harus mengonsepkan dampak sosial dan dampak lainnya. SROI kemudian merefleksikan kebutuhan, prioritas dan peran potensial dan yang sebenarnya dari para pemangku kepentingan di dalam implementasi strategi adaptasi (Chaudhury 2012). Berbeda dengan analisis biaya-manfaat tradisional, SROI digunakan untuk menganalisis perubahan yang relevan bagi masyarakat atau organisasi yang mengalaminya atau yang ikut andil dalam proses ini.

SROI didasarkan pada teori perubahan (Gambar 1), yang memperhitungkan rantai peristiwa dan hasil yang terkait dengan suatu intervensi tertentu. Teori ini mengidentifikasi apa saja dan bagaimana suatu nilai dibentuk dan oleh siapa, dan siapa yang mengambil manfaatnya serta bagaimana caranya. Pendekatan ini mengamati bagaimana keluaran 


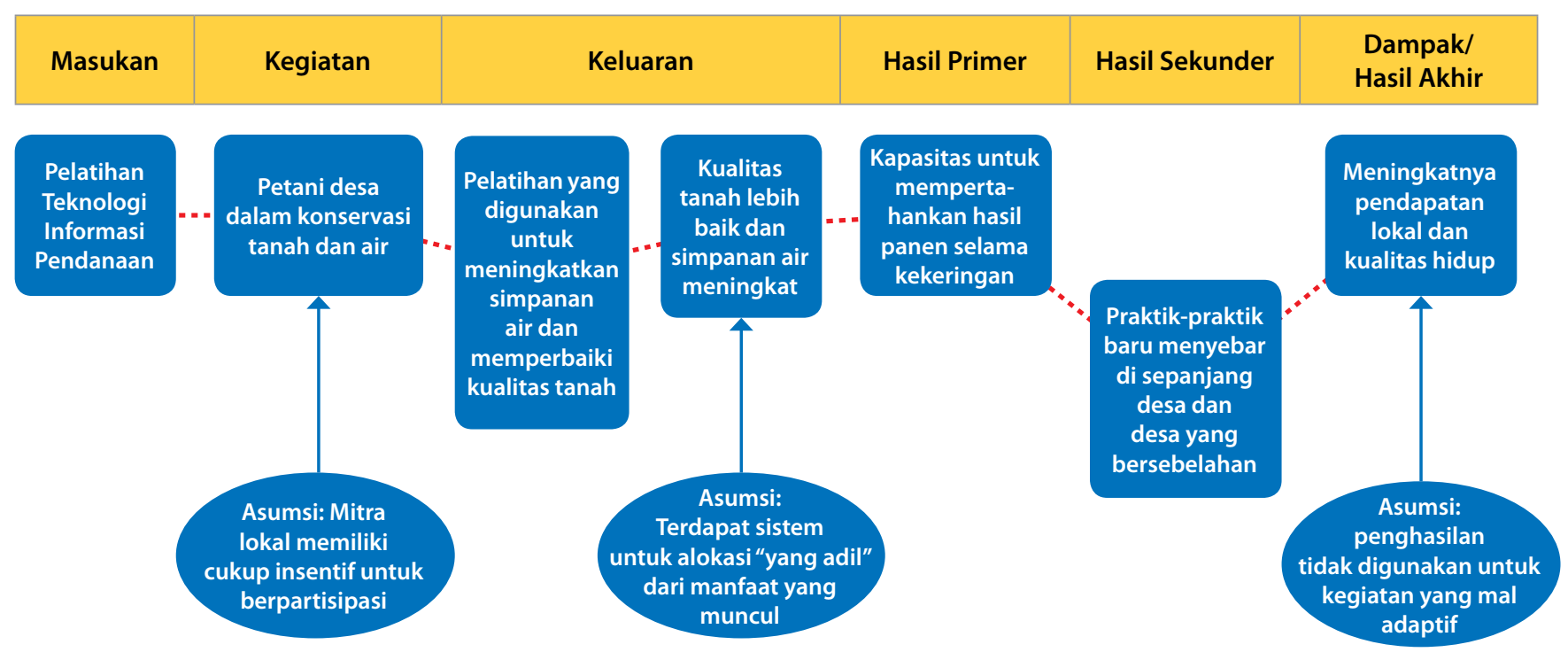

Gambar 1. Contoh teori perubahan

Sumber: Spearman dan McGray, WRI (2011)

digunakan atau akan digunakan untuk membentuk nilai dan mengidentifikasi perubahan-perubahan atau manfaat awal, dan juga keluaran yang berjangka waktu dan ruang yang lebih panjang. Teori perubahan secara jelas mengartikulasikan asumsi di balik hasil-hasil awal, menengah dan jangka panjang dan bagaimana mereka saling terkait, dan juga persyaratan yang harus terpenuhi agar hasil-hasil ini dapat terwujud.

SROI dapat digunakan untuk evaluasi maupun prakiraan. Analisis SROI evaluatif dilakukan bersamaan berdasarkan hasil aktual intervensi masa lalu atau yang sedang berlangsung. Analisis prakiraan bermaksud untuk memprediksi sejauh mana dampak dan nilai sosial akan terbentuk jika kegiatan yang direncanakan mencapai hasil yang diinginkan. Analisis prakiraan SROI khususnya bermanfaat ketika merencanakan suatu kegiatan, karena dapat menunjukkan bagaimana memaksimalkan investasi dan menunjukkan hambatan-hambatan yang harus ditanggulangi. Analisis ini juga bermanfaat untuk mengidentifikasi hal-hal yang harus dipantau dan dievaluasi ketika proyek atau program telah beroperasi secara keseluruhan.

SROI telah diterapkan secara luas untuk memprakirakan dan mengevaluasi nilai sosial di sektor nirlaba untuk program-program, seperti pelatihan keterampilan untuk kelompokkelompok terpinggirkan, perumahan dan layanan pemberdayaan masyarakat, rehabilitasi kesehatan mental dan perkebunan masyarakat kebanyakan di negara-negara Barat. Baru sekarang ini prakiraan SROI diterapkan dalam kaitannya dengan adaptasi perubahan iklim, sebagai bagian dari Program Penelitian CGIAR mengenai Perubahan Iklim, Pertanian dan Ketahanan Pangan (Sova dkk. 2012). Penelitian menunjukkan bahwa kerangka kerja SROI bermanfaat ketika merencanakan kegiatankegiatan adaptasi dan untuk mengukur kemungkinan dampak intervensi adaptasi. Agar kerangka kerja SROI dapat lebih diterapkan ke dalam perencanaan adaptasi dan proyeksi biaya yang terkait, Sova dkk. (2012) menggabungkan beberapa prinsip utama dan komponen praktis dari adaptasi berbasiskan masyarakat, pengkajian perdesaan partisipatif dan pendekatan-pendekatan berbasiskan kekuatan untuk pembangunan. Kerangka kerja prakiraan yang disempurnakan telah memperluas sifat pendekatan ini dari bawah ke atas (bottom-up) dengan menyelenggarakan lokakarya partisipatif di mana masyarakat dibantu untuk merancang intervensi adaptasi mereka sendiri berdasarkan nilai-nilai dan kapasitas mereka. 


\section{Lokasi dan Konteks Studi}

\subsection{Lokasi Studi}

Desa Setulang (Kabupaten Malinau, sekarang termasuk dalam Provinsi Kalimantan Utara) dipilih sebagai lokasi studi setelah berkonsultasi dengan tim Program Hutan dan Perubahan Iklim (FORCLIME) GIZ. Meskipun Setulang merupakan fokus perencanaan adaptasi berbasis masyarakat, keseluruhan kabupaten diperhitungkan dalam analisis iklim dan kerentanan.

Lokasi di Setulang merupakan bagian dari Proyek Hutan Rakyat (Community Forest Project) yang didukung oleh GIZ FORCLIME, yang melaksanakan kegiatan-kegiatan percontohan REDD+. Sasaran kegiatan-kegiatan FORCLIME di Kalimantan adalah untuk membantu pemerintah daerah dalam memperkenalkan pengelolaan hutan lestari, menetapkan unit-unit pengelolaan hutan dan memastikan kondisi awal yang diperlukan bagi kegiatan-kegiatan percontohan REDD+.

Desa Setulang (3 ${ }^{\circ} 27^{\prime} 12^{\prime \prime L U, ~} 116^{\circ} 29^{\prime} 56^{\prime}$ BT) terletak di Daerah Aliran Sungai (DAS) Malinau di pertemuan antara Sungai Setulang dan Malinau, $29 \mathrm{~km}$ ke arah hulu dari Kota Malinau, ibukota kabupatennya (Wunder dkk. 2008). DAS Malinau merupakan wilayah perdesaan yang paling padat populasinya dan paling berkembang di wilayah kabupaten ini, meski kepadatan penduduknya secara keseluruhannya bisa dikatakan rendah. Total wilayah masyarakat di Setulang adalah 11.530 ha, yang 5.314 ha di dalamnya merupakan lahan berhutan yang dilindungi oleh hukum adat (Tane' Olen) (Gambar 2). Sensus resmi tahun 2010 menyebutkan jumlah penduduk yang tinggal di Setulang adalah 883 jiwa, semua merupakan anggota kelompok suku Dayak Kenyah Oma’ Long.

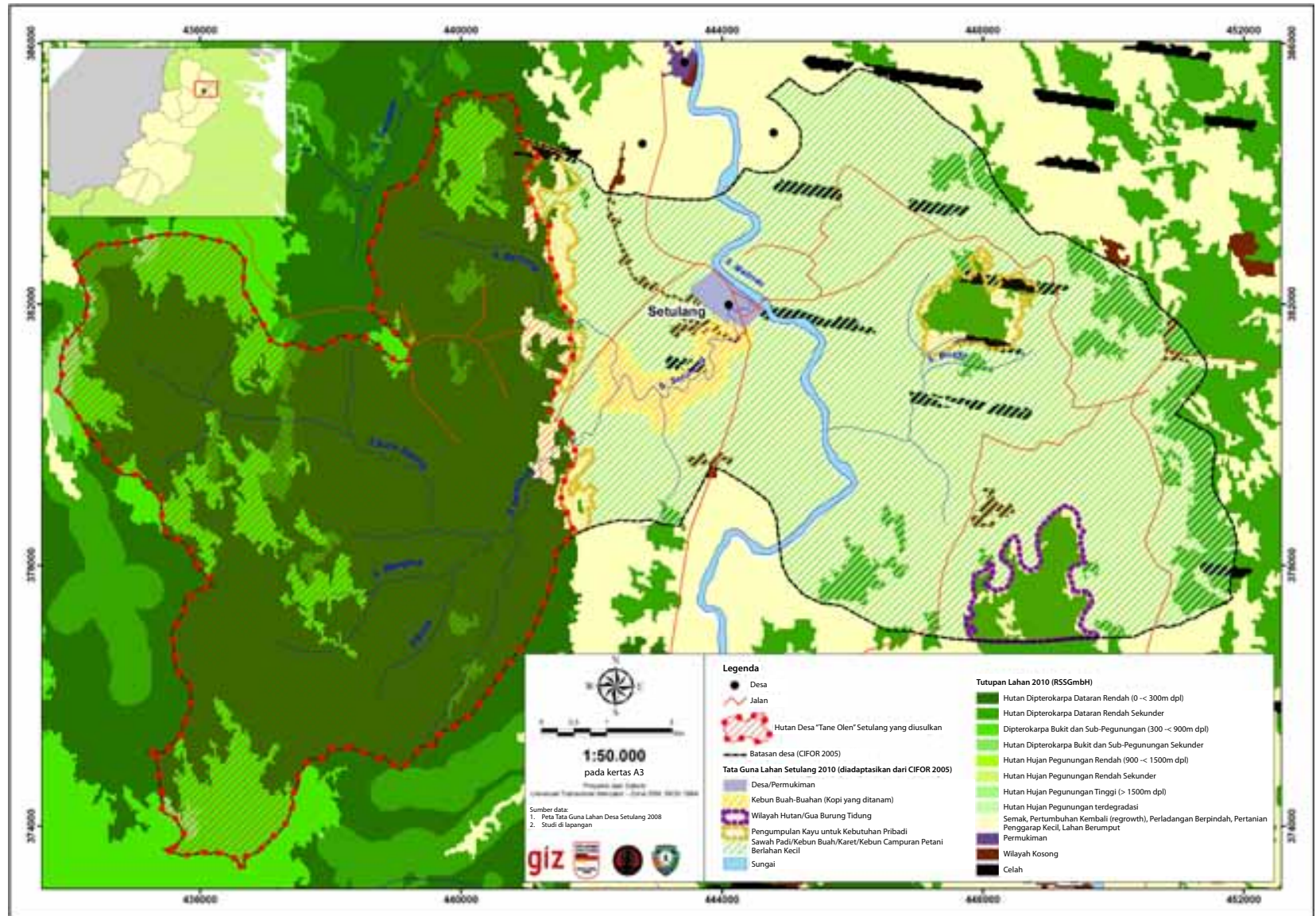

Gambar 2. Peta hutan Tane' Olen dan Desa Setulang

Sumber:Timo Beiermann/GIZ FORCLIME 
Masyarakat Setulang memiliki sejarah panjang dalam melestarikan dan melindungi hutan Tane' Olen yang mereka keramatkan melalui hukum dan lembaga pengelolaan adat. Dengan bantuan GIZ FORCLIME, pada 2011 masyarakat mengajukan pengakuan hak-hak mereka atas Tane' Olen secara hukum dan resmi melalui skema Hutan Desa. Pada April 2012, Tane' Olen, yaitu Hutan Desa yang diusulkan untuk Setulang, menjalani verifikasi lapangan untuk memastikan bahwa lokasinya tidak tumpang tindih dengan izin atau klaim yang lain. FORCLIME mendukung persiapan desa dalam aspek teknis dari verifikasi, seperti menyempurnakan rancangan peta yang telah dikembangkan sebelumnya oleh CIFOR dan Dinas Kehutanan Malinau, dan memfasilitasi koordinasi antara masyarakat, pemerintah kabupaten dan tim verifikasi lapangan yang terdiri dari petugas-petugas dari instansi pemerintah setempat dan perwakilan dari badan pengelolaan Tane' Olen. Verifikasi lapangan menyebutkan bahwa Hutan Desa Setulang memenuhi semua persyaratan hukum. Pengajuan Setulang didukung oleh pemerintah kabupaten dan provinsi, namun pengesahan akhir dari Kementerian Kehutanan mengalami penundaan.

Walaupun Tane' Olen secara aktif dilindungi oleh Setulang, wilayah berhutan Malinau mengalami tekanan dari berbagai pemicu perubahan pemanfaatan lahan. Pemicu utama deforestasi adalah konversi menjadi perkebunan kelapa sawit, pertambangan dan pertanian, pertumbuhan populasi dan pembalakan liar. Terdapat rencana untuk perkebunan kelapa sawit dan konsesi pertambangan yang terletak dekat dengan Setulang; ini tidak akan merambah hutan Tane' Olen namun diprakirakan akan memengaruhi wilayah desa yang lebih luas.

\subsection{Konteks di Malinau dan Setulang}

Kabupaten Malinau merupakan bagian dari Provinsi Kalimantan Timur pada saat studi ini dilakukan, namun saat ini merupakan salah satu dari empat kabupaten yang membentuk Provinsi Kalimantan Utara yang baru pada Oktober 2012. Mengingat Malinau memiliki hutan alam terbesar yang tersisa di Provinsi Kalimantan Timur, hanya 15\% dari Kalimantan Timur yang saat ini berhutan sejak Kalimantan Utara dibentuk.

Kabupaten yang terkunci oleh daratan ini luasnya $42.000 \mathrm{~km}^{2}$, di mana $90 \%$ di dalamnya secara resmi ditetapkan sebagai lahan hutan negara. Wilayah
Malinau memiliki hutan dipterokarpa yang saling bersinambung terbesar yang tersisa di Asia Tenggara. Hutan ini memiliki keanekaragaman hayati yang sangat kaya, juga jenis-jenis kayu berkualitas tinggi, sebuah karakter yang menimbulkan tekanan antara tujuan-tujuan konservasi dan pembangunan (Moeliono dan Limberg 2009). Sebagian besar dari hutan dataran rendah yang bisa diakses di kabupaten ini, seperti wilayah di sepanjang Sungai Malinau bagian bawah, telah terdegradasi oleh pembalakan, pertambangan dan perladangan berpindah yang ekstensif.

Penduduk di Malinau berjumlah sekitar 80.000 orang menurut sensus 2010. Mereka terdiri dari paling sedikit 19 kelompok suku, termasuk kelompok terbesar pengumpul-pemburu Punan di Kalimantan (Moeliono dan Limberg 2009). Desadesa yang lebih terpencil amat bergantung pada pengumpulan hasil hutan, sedangkan masyarakat yang tinggal di hilir sebagian besar bergantung pada pertanian untuk penghidupan mereka, terutama perladangan berpindah (Levang 2002; Moeliono dan Limberg 2009).

Pertanian dan kehutanan merupakan sektor ekonomi utama di Malinau, walaupun pertambangan, konstruksi, perdagangan, dan jasa juga telah berkembang cepat (Moeliono, dkk. 2007).

Pertambangan mungkin merupakan sektor terbesar dan terpenting bagi perekonomian tunai, meskipun belum terkonfirmasi dengan statistik yang akurat. Kehutanan dan hasil hutan bukan kayu (HHBK) berkontribusi sekitar 40\% dari PDB Malinau (DNPI dan GoEK 2010). Mengingat kondisi tanah di wilayah kabupaten curam dan rawan erosi serta miskin hara dan asam, lahan yang cocok untuk produksi pangan berkelanjutan menjadi terbatas; sebagian besar lahan ini berada di bagian tengah dan atas Malinau (Moeliono dkk. 2009).

Walaupun lebih dari separuh penduduk dikategorikan miskin, dengan angka pasti yang bervariasi antardata statistik (Moeliono dkk. 2007), tidak ada yang mengalami kelaparan (Levang 2002). Sebaliknya, kemiskinan mereka terkait dengan kurangnya akses ke fasilitas pendidikan dan kesehatan, terutama di daerah terpencil. Sebelumnya pemerintah telah berusaha untuk mengurangi kemiskinan di daerah-daerah ini dengan memindahkan desa hilir agar lebih dekat ke ibukota kabupaten. Mengingat pendekatan ini tidak lagi dianggap layak, fokus telah bergeser ke pembangunan jalan. 
Seluruh masyarakat lokal telah berpindah lokasi beberapa kali dalam beberapa dekade terakhir karena banjir, penyakit, gagal panen atau perang suku, demikian juga perpindahan pemukiman melalui program-program pemerintah (Sheil 2002). Namun banjir terjadi berulang kali karena kebanyakan desa terletak di dataran rendah di tepi sungai. Pergeseran lokasi telah menimbulkan konflik di antara masyarakat yang menandai sejarah Malinau (Sudana 2009). Karakter konflik umumnya menyangkut batas desa, lahan pertanian, persaingan atas keuntungan dari kayu dan hasil hutan bukan kayu; atau perambahan pembalakan, pertambangan maupun konsesi perkebunan kelapa sawit (termasuk skema-skema kompensasi lahan dan polusi atau ketiadaanya). Salah satu sebab konflik yang mendasar adalah kurangnya kejelasan tentang batas desa dan hak atas lahan pertanian, sehingga masingmasing kelompok suku yang menempati wilayah tersebut meyakini dasar yang berbeda atas klaim lahan (Sudana 2009). Konflik terkait hak atas lahan meningkat tajam setelah pemerintah mendorong strategi relokasi masyarakat.

Secara historis, tenurial terkait dengan adat yang didefinisikan sebagai kepercayaan budaya dan hakhak, serta praktik-praktik adat, hukum dan lembaga masyarakat (Moeliono dkk. 2009). Namun, adanya campuran yang kompleks antara aturan formal dan informal, penegakan peraturan pemerintah menjadi bermasalah. Hak-hak adat dapat memperoleh pengakuan hukum formal apabila masyarakat atau desa memenuhi sejumlah kriteria tertentu dan lolos verifikasi.
Masyarakat Setulang pernah mengalami konflik baik dengan perusahaan pembalakan yang merambah Tane' Olen maupun dengan desa-desa tetangga yang mengklaim lahan tersebut. Tane' Olen didominasi oleh hutan dipterokarpa dataran rendah dengan beberapa wilayah bukit dan hutan dipterokarpa pegunungan bawah dan hutan dipterokarpa sekunder. Hutan ini merupakan sumber penting untuk perburuan, hasil hutan bukan kayu (HHBK), bahan bangunan, serta air bersih untuk Setulang. Oleh karena itu, hanya pengumpulan HHBK secara lestari yang diizinkan, seperti yang diatur oleh adat dan dipantau oleh Badan Pengelola Tane' Olen.

Selama beberapa tahun terakhir, masyarakat Setulang mengkhawatirkan kurangnya ketersediaan lahan, tidak hanya karena pertumbuhan penduduk dan kebutuhan perluasan desa, namun juga karena adanya delineasi wilayah desa, operasi pembalakan, program-program reforestasi dan rencana untuk konsesi pertambangan dan kelapa sawit (Iwan 2006; Iwan dan Limberg 2009).

Perekonomian Setulang bertumpu pada kombinasi dari pertanian subsisten, penjualan sisa panen, khususnya beras, di Kota Malinau, pengumpulan berbagai hasil hutan, dan menangkap ikan (Iwan 2006; Wunder dkk. 2008). Pertanian utama adalah ladang, selain berkebun dan wanatani semi permanen. Pendapatan dari luar pertanian terutama diperoleh dari penghasilan para pemudanya yang bekerja untuk perusahaan kayu di Malaysia atau negara lain. Ekoturisme masih dalam tahap awal pengembangan. Setulang tidak dianggap miskin berdasarkan standar setempat. 


\section{Metode}

\subsection{Lokakarya Masyarakat}

Studi ini menggunakan pendekatan perencanaan adaptasi berbasis masyarakat seperti yang dikemukakan oleh Sova dkk. (2012) dan CARE International (sebuah daftar sumber-sumber yang bermanfaat seperti CARE International's Community-based Adaptation Toolkit, pada http:// www.careclimatechange.org/tk/cba/en/, tercantum pada lampiran buku panduan yang akan datang).

Lokakarya partisipatif dua hari (22-23 Juni 2012) yang digelar di Desa Setulang dihadiri oleh 21 anggota masyarakat, termasuk kepala desa dan perwakilan kelompok-kelompok dan pejabat desa, seperti Kelompok Perempuan, Kelompok Pemberdayaan Masyarakat dan Badan Pengelola Tane' Olen. Sasaran utama lokakarya adalah untuk menetapkan penyebab mendasar kerentanan, memahami bagaimana iklim merupakan tantangan lebih luas yang dihadapi oleh masyarakat dan menyatukan nilai-nilai dan prioritas masyarakat ke dalam pemilihan, perencanaan dan evaluasi intervensi adaptasi. Perhatian khusus diberikan pada sumber daya hutan dan pohon serta peran mereka dalam menghadapi dan mengadaptasi strategi.

Kegiatan-kegiatan yang dilakukan adalah:

1. Mengidentifikasi nilai-nilai dan aset masyarakat kemudian mengurutkannya berdasarkan prioritas (dalam kelompok-kelompok yang dipisahkan berbasis jender dan dalam sesi pleno);

2. Mengidentifikasi tantangan lingkungan dan tantangan lainnya kemudian mengurutkannya berdasarkan tingkat kepentingan (dalam kelompok-kelompok terpisah dan diskusi pleno, kemudian pemungutan suara);

3. Mengidentifikasi berbagai tanggapan historis dan strategi penanggulangan atas sejumlah tantangan serta mengkaji keefektifan;

4. Mengembangkan visi untuk masa depan melalui pemetaan masyarakat (dalam kelompok-kelompok terpisah berbasiskan jender);
5. Merancang dan memilih intervensi adaptasi prioritas dengan memunculkan aspirasi bersama anggota masyarakat serta melakukan pemungutan suara berdasarkan kepentingan relatif masing-masing bentuk adaptasi;

6. Merencanakan implementasi intervensi prioritas;

7. Mengidentifikasi biaya dan manfaat dari dampak keseluruhan intervensi prioritas dari perspektif para anggota masyarakat, juga dalam kaitannya dengan pengelolaan hutan dan REDD+ melalui suatu diskusi kelompok terpisah.

Ancaman dan tantangan yang diidentifikasi oleh anggota masyarakat dikelompokkan ke dalam klasterklaster (Gambar 3). Dalam suatu diskusi pleno, peserta mengidentifikasi dan memetakan hubungan antara berbagai tantangan tersebut.

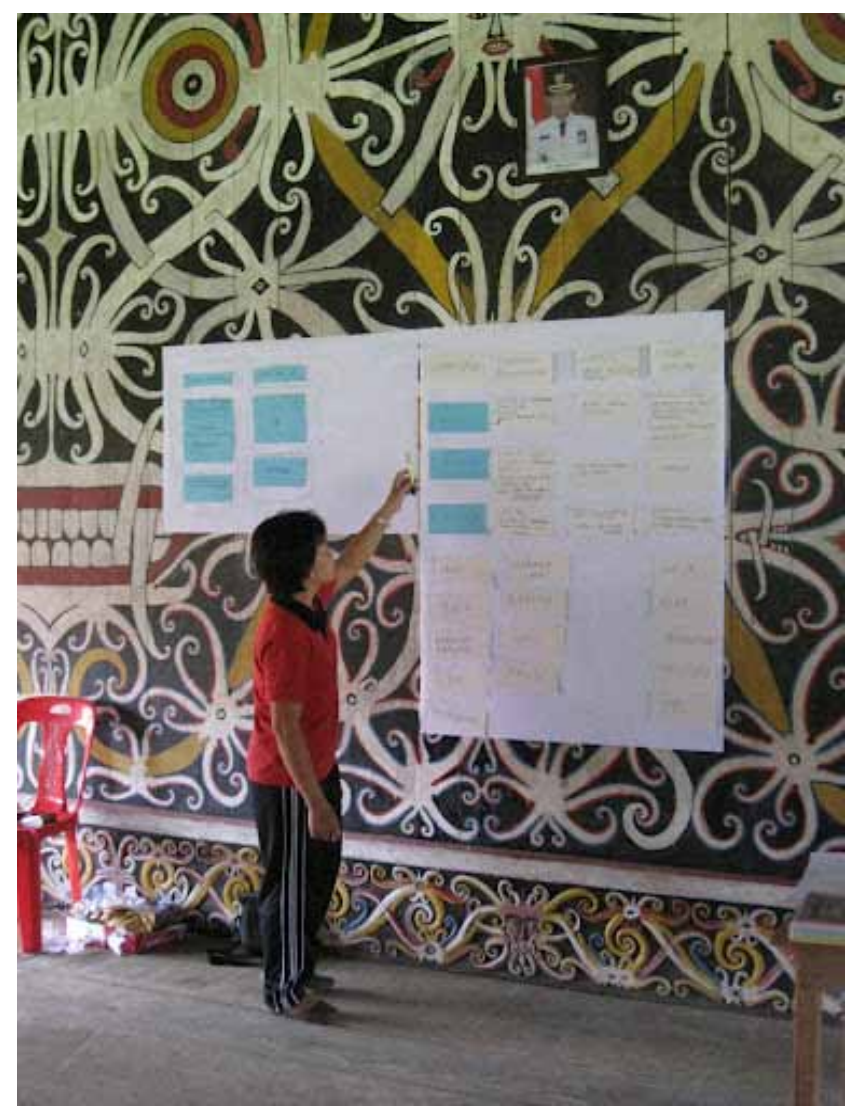

Gambar 3. Kegiatan lokakarya: Menempatkan aset dan tantangan yang penting ke dalam klaster tematis 
Prinsip-prinsip dan alat bantu adaptasi berbasis masyarakat diaplikasikan dalam lokakarya ketika mengembangkan dan mengurutkan intervensi adaptasi dalam konteks berbagai tekanan. Anggota masyarakat diminta untuk membayangkan kondisi desa mereka dalam 10 tahun ke depan lewat sebuah skenario di mana sejumlah tekanan dan tantangan ditunjukkan secara terpadu dengan sedapat mungkin menggunakan aset dan sumber daya yang tersedia (alam, keuangan, manusia, fisik dan sosial). Sepuluh tahun dianggap sebagai batasan waktu yang tepat untuk Setulang. Karakteristik masa mendatang yang diinginkan kemudian dikelompokkan menjadi sebuah cara untuk memandu pengurutan dan perencanaan atas intervensi adaptasi 'tanpa penyesalan' berdasarkan kebutuhan, aspirasi dan kapasitas masyarakat.

Untuk latihan penggambaran masa depan, para peserta membentuk kelompok-kelompok jender dan membuat peta desa masa depan (Setulang dalam 10 tahun); kelompok-kelompok ini kemudian memaparkan peta mereka dan menjelaskan perubahan-perubahannya. Karakteristik masa depan dikelompokkan dalam klaster dan disusun kembali menjadi pernyataanpernyataan (aspirasi) untuk digunakan dalam perencanaan strategi. Para peserta juga diminta untuk memilih prioritas dari masing-masing klaster aspirasi, dengan fokus pada strategi yang melibatkan pemanfaatan aset yang tersedia.

Rencana awalnya adalah untuk menggunakan 'back casting', sebuah proses sistematis bergerak mundur dari situasi masa depan yang diinginkan hingga terkini dengan terus bertanya "apa yang harus kita lakukan untuk mencapai hal ini?” (Sova dkk. 2012). Namun, berdasarkan saran fasilitator lokakarya yang memahami masyarakat dengan baik, penggunaan prakiraan dirasa lebih tepat. Memprakirakan melibatkan prediksi semua konsekuensi, yang disengaja maupun tidak disengaja disertai biaya dan manfaat, dari suatu intervensi dengan secara sistematis maju dari kondisi sekarang ke situasi masa depan yang diinginkan dengan menandai tonggak progresif di sepanjang waktu. Daftar aset prioritas masyarakat ditempatkan pada posisi yang penting selama latihan perencanaan untuk merangsang diskusi tentang bagaimana cara terbaik untuk pemanfaatannya selama implementasi.

\subsection{Wawancara dengan Pemangku Kepentingan di Organisasi Tingkat Kabupaten}

Mengingat jadwal individu menyulitkan penyelenggaraan suatu lokakarya dengan para pemangku kepentingan tingkat kabupaten, seperti instansi-instansi pemerintah dan LSM, maka dilaksanakan wawancara semiterstruktur perorangan. Pemangku kepentingan yang diwawancarai adalah sebagai berikut:

- Tiga pemangku kepentingan dari Dinas Kehutanan kabupaten: kepala dinas, kepala bagian lingkungan hidup, kepala bagian konservasi

- Kepala Dinas Pertanian kabupaten

- Kepala Dinas Pemberdayaan Masyarakat kabupaten

- Kepala Badan Perencanaan dan Pembangunan Daerah (Bappeda)

- Kepala Bagian Penyuluhan Dinas Perkebunan Daerah

- Wakil Direktur Kantor Taman Nasional Kayan Mentarang

- Kepala Dinas Lingkungan Hidup kabupaten

- Kepala Bagian HHBK pada Dinas Industri dan Kerja sama kabupaten

- Anggota staf senior dari World Wildlife Fund (WWF) Malinau.

Sasaran utama wawancara dengan para pemangku kepentingan tingkat kabupaten adalah untuk menyampaikan hasil lokakarya masyarakat berikut analisis iklim dan kerentanan. Tujuannya adalah untuk memperoleh persepsi tentang tantangan kritis yang dihadapi kabupaten dalam kaitannya dengan adaptasi dan pengelolaan hutan/REDD+. Selain itu juga untuk mendiskusikan biaya, manfaat, tantangan, peluang dan risiko yang terkait dengan adaptasi intervensi prioritas yang diidentifikasi oleh masyarakat. Panduan wawancara semi terstruktur yang digunakan tercantum pada lampiran.

Setelah wawancara tingkat kabupaten selesai, para peneliti kembali mengunjungi masyarakat Setulang untuk melaksanakan diskusi yang lebih mendalam tentang dua strategi adaptasi prioritas yang dipilih untuk analisis dalam studi ini. Enam anggota masyarakat diwawancarai secara terpisah untuk mendapatkan pemahaman yang lebih baik tentang peluang dan tantangan yang menyangkut 
implementasi strategi. Wawancara tersebut tidak terstruktur; pihak yang diwawancarai didorong untuk berbicara secara terbuka dan apa adanya tentang berbagai isu yang dikhawatirkan dan secara terperinci.

\subsection{Analisis Perubahan Iklim dan Kerentanan}

\subsubsection{Kerangka kerja}

Analisis iklim dan kerentanan dilakukan melalui kerangka kerja kerentanan, di mana kerentanan dianggap sebagai sebuah fungsi dari paparan, sensitivitas dan kapasitas adaptasi (Gambar 4).

Komponen paparan melingkupi variabilitas iklim saat ini dan prakiraan perubahan iklim masa depan, termasuk kejadian-kejadian ekstrem. Pada intinya komponen ini menggambarkan sifat dan tingkat tekanan iklim pada suatu sistem. Sensitivitas menerangkan bagaimana sistem bereaksi atas atau dipengaruhi oleh tekanan-tekanan iklim. Kapasitas adaptasi berfokus pada kemampuan sistem untuk mengakomodasi tekanan ini dan konsekuensinya agar dapat meminimalkan bencana atau memaksimalkan semua peluang. Kapasitas adaptasi dapat dipengaruhi oleh faktor-faktor seperti kesejahteraan, ketersediaan dan akses ke teknologi, pendidikan dan informasi, integritas ekosistem, dan infrastruktur (Smit dan Pilifosova 2001).

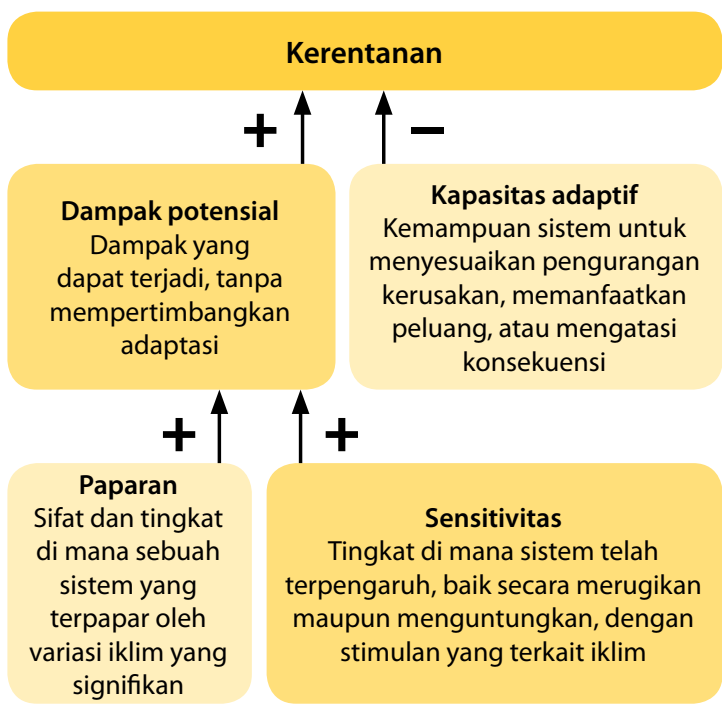

Gambar 4. Kerentanan sebagai sebuah fungsi dari paparan, sensitivitas dan kapasitas adaptif Sumber: Locatelli (2011)
Singkatnya, kerugian akibat dampak bencana iklim yang tidak diinginkan dalam sebuah sistem bergantung pada kerentanan sistem. Dampak negatif tidak terjadi semata-mata karena paparan terhadap bencana iklim, tetapi juga karena sensitivitas tinggi terhadap bencana tersebut dan keterbatasan kapasitas untuk beradaptasi dengannya.

Aksi adaptasi biasanya direncanakan dengan tujuan untuk menindaklanjuti salah satu atau beberapa elemen di dalam kerangka kerja. Mereka mungkin bertujuan untuk mitigasi sebab-sebab mendasar dari kerentanan (misalnya, memastikan akses ke sumber daya dan perawatan kesehatan) atau untuk memodifikasi peparan terhadap, dan dampak dari suatu bencana iklim tertentu (misalnya, membangun penghalang untuk melindungi permukiman dari badai pesisir). Aksi-aksi ini dapat bersifat bertahap atau transformatif. Adaptasi bertahap mengacu pada perluasan aksi-aksi dan tindakan saat ini yang sudah mulai mengurangi kerentanan, sementara aksi transformatif adalah "yang diterapkan pada skala atau intensitas yang jauh lebih besar dan/atau benar-benar baru pada suatu daerah atau sistem tertentu" (Kates dkk. 2012).

Namun demikian, bencana iklim dan dampaknya jarang muncul sendiri. Biasanya suatu sistem sudah berada di bawah tekanan berbagai pemicu yang sering berinteraksi, menimbulkan dampak ganda dan umpan balik kerentanan. Sistem sosio-ekologis di Malinau berada dalam lingkungan multi pemicu, di mana banyak di antaranya memengaruhi sensitivitas dan kapasitas untuk beradaptasi dengan tantangan lain, khususnya yang terkait dengan iklim. Seperti dibahas di bawah ini, degradasi hutan dan deforestasi, sebagai contoh, memperbesar risiko kebakaran hutan dan membuat ekosistem lebih sensitif terhadap kekeringan. Dengan kebakaran yang berulang, sensitivitas terhadap gangguan di masa mendatang (termasuk kebakaran baru) meningkat tajam.

Analisis ini berfokus pada isu-isu utama bagi masyarakat di Setulang dan Malinau secara lebih luas. Analisis iklim dan kerentanan bertujuan untuk melengkapi konsultasi dan persepsi para pemangku kepentingan dengan memberikan masukan tambahan dari literatur tentang kemungkinan skenario dan ambang kerentanan kritis. Keduanya bertujuan untuk memberikan masukan bagi perencanaan adaptasi dan menjadi dasar bagi suatu pengkajian awal tentang ketangguhan intervensi adaptasi prioritas di bawah sejumlah skenario iklim yang mungkin terjadi. 


\subsubsection{Paparan}

Paparan menyangkut variabilitas, tren dan keekstreman iklim saat ini maupun yang diprakirakan. Paparan menyangkut sifat dan tingkat tekanan iklim pada suatu sistem pada tingkat dan skala yang berbeda. Tipe-tipe paparan yang berbeda mengenai bencana iklim dapat terjadi pada skala waktu yang berbeda. Paparan dapat terkait dengan frekuensi dan intensitas kejadian abnormal atau ekstrem (misalnya, badai yang lebih besar atau lebih sering terjadi), frekuensi dan intensitas variabilitas iklim (misalnya, pergeseran bulan atau musim penghujan dan kemarau, serta fluktuasi temperatur minimum dan maksimum harian), pergeseran musim dalam waktu dan ruang (misalnya, periode penghujan yang panjang selama musim kemarau) atau tren yang terus bertambah dalam jangka panjang dan perubahan titik awal yang lambat (misalnya, kenaikan $1^{\circ} \mathrm{C}$ suhu rerata tahunan pada tahun 2050).

Mengingat tidak ada stasiun observasi meteorologi di Kabupaten Malinau, kami menggunakan set data yang diinterpolasi, yaitu, set data yang menggunakan pengukuran dari beberapa stasiun pengamatan cuaca di dunia dan menerapkan algoritma teruji untuk mendapatkan data iklim dari titik manapun pada grid global. Kami menggunakan set data WorldClim (http://www.worldclim.org; Hijmans dkk. 2005) untuk iklim rerata, dan pusat data iklim Tyndall Centre's Climate Research Unit (www.cru. uea.ac.uk/home; Mitchell dan Jones 2005) untuk data tahunan sebelumnya dan tren iklim. Titik dekat Kota Malinau (ditandai dengan bintang pada Gambar 5), yang juga berlokasi di dekat Setulang, digunakan sebagai titik acuan untuk memperoleh semua data iklim.

WorldClim memiliki set lapisan iklim global (grid iklim) dengan resolusi spasial sekitar $1 \mathrm{~km}$. Interpolasi dari data yang terobservasi mewakili tahun 1950-2000. Set data dari Unit Penelitian Iklim (Climate Research Unit) memuat variasi iklim dari bulan ke bulan pada resolusi 0,5 busur derajat (sekitar $50 \mathrm{~km}$ ), berdasarkan catatan iklim pada lebih dari 4.000 stasiun cuaca di seluruh dunia. Pada kedua set data, kami hanya memperhitungkan dua variabel iklim: curah hujan dan suhu.

Tren iklim di masa depan diperoleh dari set data TYN SC 2.0 dari Tyndall Centre's Climate Research Unit (Mitchell, dkk. 2003). Set data TYN SC 2.0 memuat grid bulanan dari iklim yang dimodelkan termasuk tutupan awan, kisaran suhu harian, curah

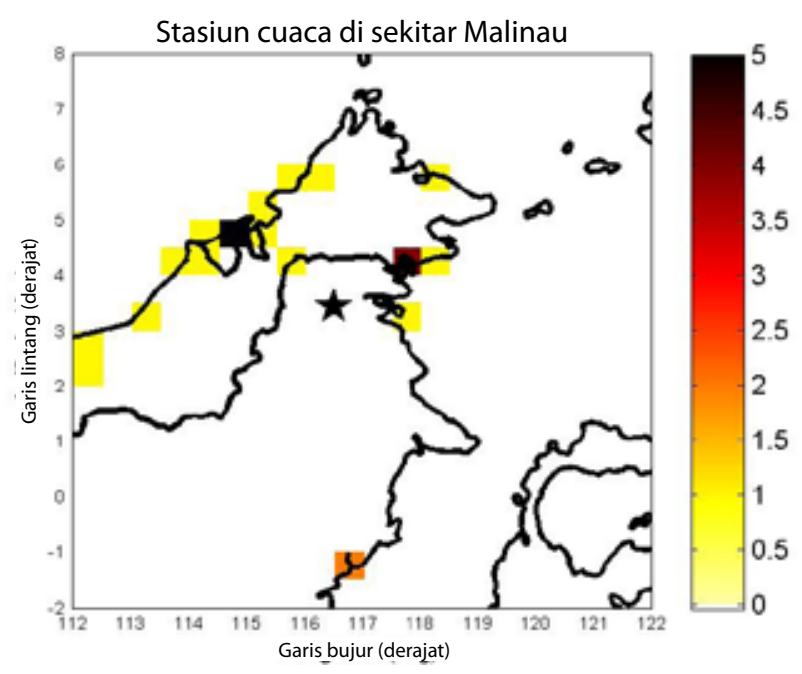

Gambar 5. Stasiun cuaca di sekitar Malinau

Sumber: CRU TS 3.1, Mitchell dan Jones (2005)

hujan, temperatur dan tekanan uap untuk periode 2001-2100, dan meliputi permukaan lahan global pada resolusi 0,5 derajat $\left(50 \mathrm{~km}^{2}\right)$.

Kami menggunakan keluaran untuk empat model sirkulasi umum (general circulation models/GCM), yang merupakan perwakilan matematis dari sistem iklim, yang mensimulasikan proses-proses fisik dan dinamis yang menentukan iklim global; modelmodel komputer ini membagi bumi ke dalam sel-sel grid horisontal dan vertikal, yang masingmasing sel mewakili suatu kondisi iklim spesifik untuk suatu waktu berdasarkan suatu set persamaan. Empat GCM yang digunakan adalah CGCM2, CSIRO mk 2 (CSIRO2), DOE PCM (PCM) dan HadCM3 (HAD3).

Kami mengombinasikan GCM tersebut dengan empat skenario emisi dari Panel Antar Pemerintah untuk Perubahan Iklim (IPCC; http://www.ipcc. ch/ipccreports/sres/emission/index.php?idp=0): A1FI (dunia yang terintegrasi yang ditandai dengan pertumbuhan ekonomi yang pesat dan tingginya penggunaan bahan bakar fosil), A2 (dunia yang lebih terpilah, pembangunan ekonomi berorientasi regional), B1 (dunia yang lebih terintegrasi dan lebih ramah lingkungan) dan B2 (dunia yang lebih terpilah dan lebih ramah lingkungan). Data dihitung untuk tahun 2020, 2050 dan 2080, menggunakan lokasi yang dekat dengan Kota Malinau sebagai titik referensi (seperti di atas).

Data sekunder yang relevan dari analisis iklim lainnya (berbagai laporan nasional dan penilaian kerentanan) juga diikutsertakan ke dalam paparan. 


\subsubsection{Kapasitas sensitivitas dan adaptasi} Derajat sensitivitas mengindikasikan seberapa responsif suatu sistem terhadap variabel-variabel iklim tertentu atau keekstreman. Sistem yang lebih sensitif akan menunjukkan perubahan komposisi atau struktur yang lebih besar sebagai respon atas munculnya gangguan.

Sensitivitas sumber-sumber dan sektor utama terhadap bencana iklim (misalnya, sistem produksi pertanian, kesehatan dan pemukiman) dianalisis dengan menggunakan tinjauan literatur. Sumbersumber dan sektor utama diidentifikasi dari konsultasi masyarakat dan analisis desktop. Analisis kapasitas adaptasi juga didasarkan pada persepsi pemangku kepentingan (dari masyarakat maupun responden pada tingkat kabupaten/provinsi) dan literatur.

Kapasitas adaptasi biasanya dikaitkan dengan kemampuan sistem sosio-ekologis agar tangguh terhadap gangguan dan untuk beradaptasi dengan perubahan aktual atau yang diantisipasi, baik yang bersifat eksogen maupun endogen (Plummer dan Armitage 2010). Kapasitas adaptasi sistem sosial ditentukan oleh kesesuaian sumber daya yang tersedia dan proses serta struktur sosial yang menjadi tempat mereka berfungsi dan bermediasi. Salah satu faktor paling penting yang membentuk kapasitas adaptasi individual, rumah tangga dan masyarakat adalah akses dan kontrol mereka atas sumber-sumber alam, manusia, sosial, fisik, dan keuangan. Termasuk dalam contoh sumber daya yang memengaruhi kapasitas adaptasi adalah infrastruktur irigasi dan stasiun cuaca (fisik), kelompok simpanan masyarakat dan kelompok-kelompok petani (sosial), sumber air tawar yang dapat diandalkan dan lahan produktif (alam), asuransi mikro dan sumber-sumber penerimaan yang beragam (finansial) dan pengetahuan, keterampilan dan pendidikan (manusia). 


\section{Pandangan para Pemangku Kepentingan}

\subsection{Anggota Masyarakat: Persepsi atas Sumber Daya, Tantangan dan Strategi Penanggulangan}

\subsubsection{Aset dan sumber daya}

Anggota masyarakat diminta untuk mendaftar sumber daya (lingkungan hidup, sosial, manusia, finansial, dll) dan aset nilai dalam masyarakat mereka, mengurutkannya berdasarkan pentingnya, serta menggambarkan ketersediaan dan aksesibilitasnya (Tabel 1). Baik perempuan maupun laki-laki menuliskan air, aset pertanian dan sumber daya manusia, walaupun dengan urutan yang berbeda; laki-laki juga menyebutkan sumber daya sosial, finansial dan hutan.

Para peserta mencatat bahwa sumber daya air sangat penting untuk memasak, mencuci, mandi dan transportasi. Perempuan menempatkan sumber daya air pada urutan teratas karena persediaan air bersih yang stabil sangat penting untuk sebagian besar kegiatan rumah tangga. Desa memperoleh air melalui pipa dari sumber air Tane' Olen karena polusi telah menyebabkan air sungai di Setulang tidak aman bagi kebutuhan masyarakat. Para laki-laki menuliskan bahwa pipa tersebut terlalu sempit untuk mencukupi pasokan air menuju desa dan perlu direkonstruksi.

Laki-laki menempatkan sumber daya manusia di urutan teratas, walaupun kedua kelompok sepakat atas pentingnya pengetahuan tentang pertanian, kesehatan dan perawatan kesehatan, pengelolaan hutan dan sumber daya untuk semua kegiatan perekonomian di desa. Namun demikian, banyak kaum muda dan terpelajar yang lebih memilih untuk mengejar peluang di kota.

Sumber daya pertanian didefinisikan sebagai ladang dan kebun berikut produk yang dihasilkan. Meskipun setiap rumah tangga memiliki lahan,

Tabel 1. Aset dan sumber daya dalam urutan prioritas dan kondisi saat ini (berdasarkan kelompok jender)

\begin{tabular}{|c|c|c|c|c|}
\hline \multirow[t]{2}{*}{ Peringkat } & \multicolumn{2}{|r|}{ Perempuan } & \multicolumn{2}{|r|}{ Laki-laki } \\
\hline & Sumber daya & Kondisi & Sumber daya & Kondisi \\
\hline 1 & Air & $\begin{array}{l}\text { Kualitas air sungai telah } \\
\text { memburuk. Hanya air dari sumber } \\
\text { air Tane' Olen yang masih baik. }\end{array}$ & Manusia & $\begin{array}{l}\text { Pernyataan yang sama dengan yang } \\
\text { dibuat oleh kelompok perempuan. }\end{array}$ \\
\hline 2 & Manusia & $\begin{array}{l}\text { Sumber daya manusia menurun } \\
\text { karena kaum muda yang } \\
\text { berpendidikan mencari peluang } \\
\text { di kota besar dan tidak kembali ke } \\
\text { Setulang. }\end{array}$ & Sosial & $\begin{array}{l}\text { Ikatan dan kohesi sosial yang } \\
\text { kuat sehingga mudah untuk } \\
\text { memobilisasi aksi bersama. }\end{array}$ \\
\hline 3 & Pertanian & $\begin{array}{l}\text { Panen menurun. Masih cukup } \\
\text { untuk memenuhi kebutuhan, } \\
\text { namun surplus menjadi lebih kecil. }\end{array}$ & Keuangan & $\begin{array}{l}\text { Beberapa pendanaan untuk } \\
\text { proyek masyarakat tersedia dari } \\
\text { kelompok-kelompok desa dan } \\
\text { instansi pemerintah namun tidak } \\
\text { mencukupi. }\end{array}$ \\
\hline 4 & & & Air & $\begin{array}{l}\text { Volume air dari sumber air yang } \\
\text { disalurkan ke desa tidak memadai } \\
\text { karena pipanya terlalu sempit. }\end{array}$ \\
\hline 5 & & & Hutan & $\begin{array}{l}\text { Sumber daya hutan berada } \\
\text { dalam kondisi yang baik namun } \\
\text { ketersediaan untuk generasi masa } \\
\text { depan tidak pasti. }\end{array}$ \\
\hline 6 & & & Pertanian & $\begin{array}{l}\text { Pernyataan yang sama dengan } \\
\text { yang dibuat oleh perempuan. }\end{array}$ \\
\hline
\end{tabular}


sekitar 50\% dari penduduk desa juga memiliki kebun dengan sayuran, kopi dan pohon buahbuahan. Panen dianggap cukup untuk memenuhi kebutuhan sepanjang tahun, namun penduduk desa telah melihat penurunan dalam surplus yang tersedia untuk penyimpanan dan asuransi bencana.

Sumber daya hutan dan Tane' Olen dinilai untuk kemampuan penyediaan produk yang dibutuhkan bagi ketahanan pangan dan penghidupan, sekaligus perannya untuk memastikan pasokan air bersih. Anggota masyarakat mengambil makanan dan HHBK (buah, rotan, tanaman obat dan daging satwa liar), bahan bangunan dan kayu bakar dari hutan, dan telah mulai mengembangkan ekoturisme di Tane' Olen.

Sumber daya sosial mencakup kohesi sosial, adat dan tradisi, dan jaringan kerja serta kelompok yang saling mendukung. Kelompok ini memobilisasi aksi bersama, membantu yang miskin dan rentan, mendukung kegiatan pertanian dan budaya, serta mengelola berbagai dana untuk pembangunan desa. Berbagai sumber daya ini masih dalam kondisi yang baik, menurut warga desa, berkat budaya persatuan yang cukup kuat dan saling mendukung di Setulang (Gambar 6).

Sumber daya finansial dikaitkan dengan dana yang dibutuhkan untuk membeli peralatan pertanian, bibit dan untuk fasilitas bangunan (misalnya, membangun jaringan listrik dan telekomunikasi). Walaupun bantuan finansial tersedia dari instansi pemerintah melalui kelompok-kelompok petani di Setulang dan desa lain, mereka merasa jumlah dana yang disediakan tidak mencukupi kebutuhan. Setulang memiliki kelompok simpan pinjam masyarakat namun dananya juga dianggap kurang mencukupi, khususnya untuk membangun fasilitas baru.

Baik laki-laki maupun perempuan menyebutkan pentingnya lembaga desa (Tabel 2), demikian juga lembaga dari luar yang memengaruhi kepentingan desa.

Banyaknya jumlah lembaga desa mungkin disebabkan oleh kuatnya kohesi sosial yang menjadi karakteristik Setulang. Para peserta menyebutkan lembaga-lembaga di bawah ini memiliki pengaruh terhadap desa:

1. GIZ

2. CIFOR

3. Dinas Pariwisata Kabupatan

4. Dinas Kehutanan Kabupaten

5. Dinas Penyuluh Pertanian

6. Asosiasi Kelompok Tani

7. Partai-partai politik

8. Bintara Pembina Desa atau Babinsa

9. Borneo Tropical Rainforest Initiative

Tabel 2. Kelembagaan di desa

\begin{tabular}{lll}
\hline & Nama & Penduduk yang terlibat \\
\hline 1 & Pemerintah desa & Laki-laki dan perempuan \\
2 & Parlemen desa & Kebanyakan laki-laki \\
3 & Dewan Adat & Kebanyakan laki-laki \\
4 & Lembaga Pemberdayaan Masyarakat & Laki-laki dan perempuan \\
5 & Dewan Jemaat Gereja & Laki-laki dan perempuan \\
6 & Dinas Sosial dan Budaya & Laki-laki dan perempuan \\
7 & Dinas Pemberdayaan dan Kesejahteraan Keluarga & Kebanyakan perempuan \\
8 & Dewan Pembina Tane' Olen & Laki-laki dan perempuan \\
9 & Pusat kesehatan untuk ibu, anak dan wanita hamil & Kebanyakan perempuan \\
10 & Dinas Kepemudaan & Laki-laki dan perempuan \\
11 & Dinas Kerja Sama Ekonomi & Laki-laki dan perempuan \\
12 & Dewan Antar Dinas Desa & Laki-laki dan perempuan \\
13 & Kelompok simpan pinjam berbasiskan masyarakat & Laki-laki dan perempuan \\
14 & Persekutuan Gereja Injil Indonesia & Laki-laki dan perempuan \\
15 & Badan Pendidikan Anak Usia Dini & Laki-laki dan perempuan \\
\hline
\end{tabular}




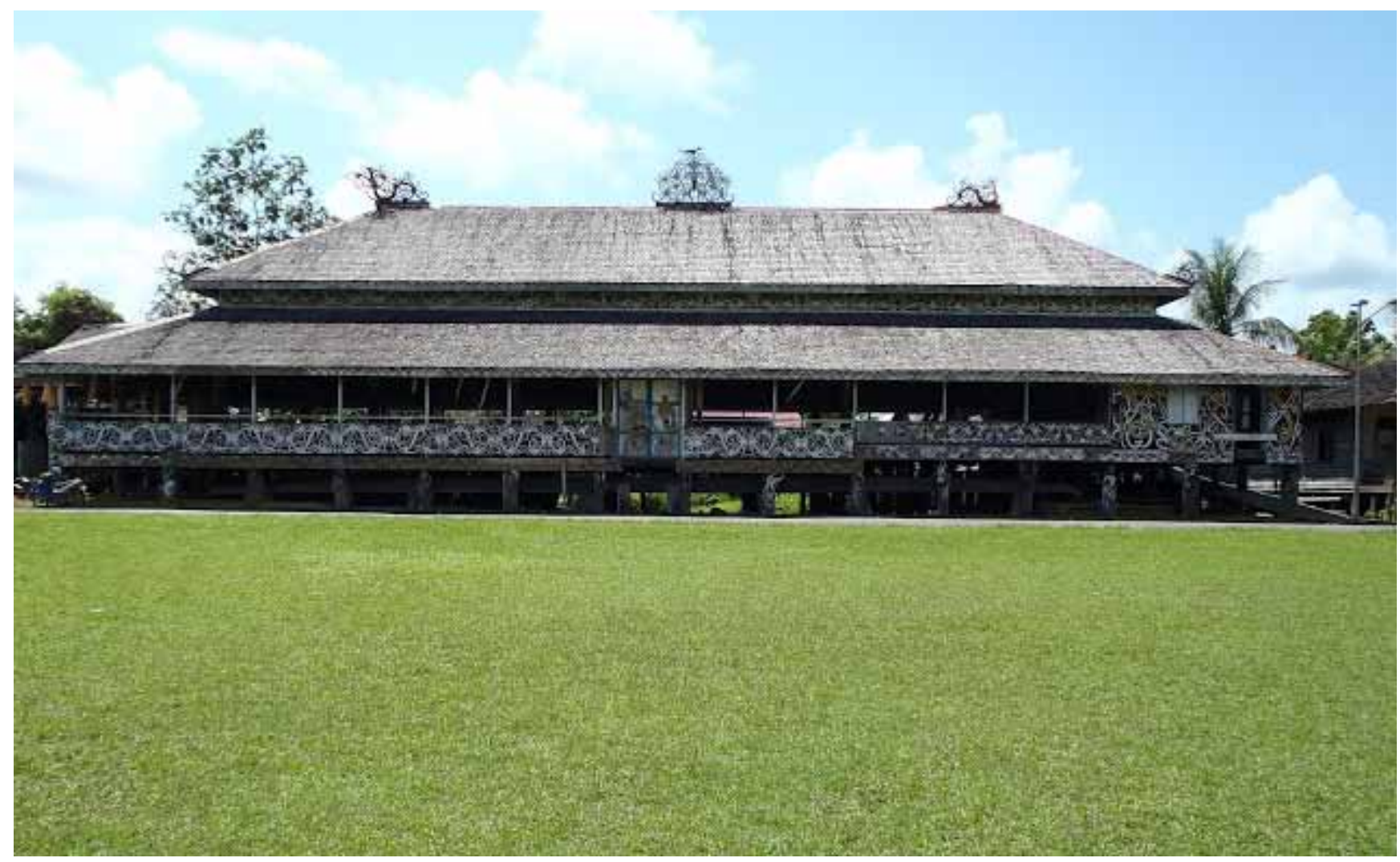

Gambar 6. Rumah adat di Setulang, tempat pertemuan desa diselenggarakan

\subsubsection{Sejumlah tantangan, bencana dan strategi penanggulangan}

Masyarakat membuat daftar tantangan dan bencana yang kemudian dirangkum menjadi delapan tantangan prioritas dan diurutkan sebagai berikut (lihat juga Tabel 3):

1. Konflik sosial terkait tenurial dengan desa-desa tetangga dan konsesi yang berdekatan

2. Penyalahgunaan alkohol dan narkoba oleh kaum muda

3. Penyalahgunaan kekuasaan politik

4. Polusi sungai

5. Banjir

6. Penyakit (diare, infeksi, dan penyakit menular)

7. Musim kemarau yang berkepanjangan

8. Pembalakan liar

Namun yang menarik adalah banjir, kekeringan dan bencana lingkungan sering terjadi di Setulang. Walaupun demikian penduduk tidak menyebutkannya sebagai masalah yang paling serius. Anggota masyarakat meyakini bahwa mereka dapat mengatasi bencana iklim, misalnya dengan meninggikan rumah mereka, mengelola hutan mereka secara berhati-hati, menyimpan surplus panen dan menjaga fasilitas penyimpanan bijibijian agar tetap aman. Namun, tantangan sosial semisal konflik memiliki dampak yang lebih serius bagi kehidupan maupun pada kemampuan mereka secara keseluruhan untuk mengatasi tantangantantangan lainnya.

Masyarakat menyadari adanya kaitan antara isu sosial dan kemampuan mereka untuk mengatasi bencana iklim. Konflik tenurial dengan desa tetangga, misalnya, membuat mereka enggan untuk menanami ladang dekat perbatasan desa. Karena itu semakin sedikit lahan yang tersisa untuk diversifikasi pertanian dan penyediaan lahan berprospek bagus untuk kaum muda. Sementara itu pembuat kebijakan setempat, yang menyalahgunakan kekuasaan politik mereka, kerap membuat kesepakatan dengan konsesi dan menjual lahan desa tanpa konsultasi dengan masyarakat. Penduduk memahami bahwa apabila lahan berhutan mereka hilang, mereka akan menjadi lebih rentan terhadap bencana yang lain karena hutan melindungi pasokan air dan berfungsi sebagai semacam bank makanan.

Konflik di Malinau meningkat setelah desentralisasi, ketika konsesi mulai mendekati desa di wilayah 
Tabel 3. Tantangan/bahaya dan strategi penanggulangan: respon masyarakat

\begin{tabular}{|c|c|c|c|}
\hline No. & Tantangan/bahaya & Strategi penanggulangan/solusi & Saran untuk perbaikan \\
\hline 1 & Konflik tenurial & $\begin{array}{l}\text { Negosiasi dengan desa lain, laporan yang } \\
\text { bersifat insidental kepada pemerintah daerah. }\end{array}$ & $\begin{array}{l}\text { Lebih banyak keterlibatan pemerintah } \\
\text { dan pihak ketiga dalam mediasi. }\end{array}$ \\
\hline 2 & $\begin{array}{l}\text { Penyalahgunaan } \\
\text { alkohol/obat-obatan }\end{array}$ & Hukum adat. & \\
\hline 3 & $\begin{array}{l}\text { Penyalahgunaan } \\
\text { kekuasaan politik }\end{array}$ & Tidak ada strategi. & Tidak ada saran. \\
\hline 4 & Polusi sungai & Pelaporan, pengajuan petisi, dan demonstrasi. & Dukungan pemerintah yang lebih besar. \\
\hline 5 & Banjir & $\begin{array}{l}\text { Meninggikan rumah. } \\
\text { Menerapkan pengelolaan sampah dengan } \\
\text { baik untuk menghindari penyumbatan } \\
\text { saluran dan sungai. } \\
\text { Memindahkah penyimpanan surplus hasil } \\
\text { panen (lumbung) ke tempat yang lebih tinggi. }\end{array}$ & $\begin{array}{l}\text { Lembaga adat desa untuk pengelolaan } \\
\text { bencana (menyelamatkan harta benda } \\
\text { masyarakat yang sedang berada di } \\
\text { ladang ketika air banjir naik). }\end{array}$ \\
\hline 6 & Penyakit & $\begin{array}{l}\text { Menghindari mandi di sungai. } \\
\text { Mencari saran untuk perawatan kesehatan. } \\
\text { Meningkatkan gizi untuk bayi dan wanita } \\
\text { hamil. }\end{array}$ & $\begin{array}{l}\text { Penggunaan kelambu di masing- } \\
\text { masing rumah tangga untuk } \\
\text { melindungi dari malaria. }\end{array}$ \\
\hline 7 & $\begin{array}{l}\text { Musim kering yang } \\
\text { lebih panjang }\end{array}$ & $\begin{array}{l}\text { Menanam tanaman yang tahan kekeringan. } \\
\text { Bersandar pada hutan untuk pangan dan } \\
\text { mata pencaharian. } \\
\text { Mencari bantuan dari otoritas. }\end{array}$ & $\begin{array}{l}\text { Diversifikasi mata pencaharian yang } \\
\text { lebih besar. } \\
\text { Kapasitas yang lebih besar untuk } \\
\text { menyimpan surplus pangan dan uang } \\
\text { tunai. }\end{array}$ \\
\hline 8 & Pembalakan liar & Hukum adat yang kuat. & $\begin{array}{l}\text { Pengakuan formal dari pemerintah } \\
\text { melalui perizinan Hutan Desa. }\end{array}$ \\
\hline
\end{tabular}

tersebut dan menawarkan kompensasi untuk mengeksploitasi lahan dan hutan mereka. Hal ini memicu sengketa batas antardesa karena kurangnya kejelasan atas hak tenurial lahan yang berarti bahwa tidak jelas desa mana yang akan meraup keuntungan yang diharapkan dari eksploitasi tersebut. Masyarakat Desa Setulang telah menolak tawaran dan telah mengalami konflik dengan perusahaan yang mencoba untuk melanggar batas wilayah mereka tanpa meminta izin.

Anggota masyarakat di Setulang merasa strategi mereka untuk menghadapi tantangan dan bencana belum membuahkan solusi jangka panjang dan berkelanjutan. Dengan adanya konflik tenurial, misalnya, Setulang telah melakukan negosiasi dengan desa yang berdekatan untuk mencoba menyepakati hal terkait batas, namun mereka merasa bahwa proses ini membutuhkan keterlibatan lebih serius dari pemerintah daerah dan mediator pihak ketiga yang mandiri untuk dapat bertindak jujur dan adil.

Untuk menghindari penyalahgunaan obat oleh kaum muda, desa telah menetapkan suatu hukum adat untuk mengatur penggunaan alkohol dan obat- obatan. Namun, karena mereka dapat membeli di desa tetangga, kerja sama yang lebih kuat antardesa dibutuhkan untuk mengatasi masalah ini.

Polusi sungai juga merupakan masalah penting, sehingga masyarakat merasa perlunya keterlibatan pemerintah daerah. Sungai di Setulang telah sangat terpolusi oleh eksplorasi pertambangan sungai di hulu dan di sekitarnya sehingga masyarakat tidak lagi aman menggunakannya untuk mandi atau kegiatan lain, karena menyebabkan penyakit kulit dan diare. Penduduk juga telah mencermati penurunan jumlah ikan yang ditangkap dari sungai. Laporan kepada instansi pemerintah, petisi terhadap perusahaan pertambangan dan demonstrasi belum terlihat pengaruhnya.

Untuk menghadapi musim kemarau yang lebih panjang dalam beberapa tahun ini, yang telah menyebabkan kegagalan panen dan pendangkalan sungai, Setulang telah menerapkan suatu strategi adaptasi proaktif dan berjangka lebih panjang, yaitu melakukan upaya untuk melestarikan hutan sehingga dapat berfungsi sebagai semacam 'bank makanan' pada saat terjadi kelangkaan. Namun, kadang- 
kadang bantuan dari pemerintah daerah dibutuhkan ketika dampak kekeringan menjadi semakin parah. Penduduk desa menyadari adanya kebutuhan untuk diversifikasi penghidupan yang lebih beragam dan kapasitas yang lebih besar untuk menyimpan surplus makanan dan uang tunai untuk meningkatkan ketahanan pangan mereka.

Ketakutan lain adalah bahwa Tane 'Olen, yang begitu penting dalam mengatasi tantangan seperti banjir dan kekeringan, bisa berada di bawah ancaman degradasi dan pembalakan dan mungkin hukum adat tidak cukup untuk menghentikan perambahan. Oleh karena itu, warga desa berharap bahwa Kementerian Kehutanan akan segera menyetujui permohonan untuk status Hutan Desa, yang artinya bahwa hak kepemilikan mereka untuk Tane 'Olen akan diakui secara resmi.

\subsection{Wawancara Tingkat Kabupaten: Persepsi atas Tantangan dan Bencana Utama di Malinau dan Setulang}

Wawancara semi terstruktur dengan para pemangku kepentingan di tingkat kabupaten digunakan untuk memperoleh persepsi mereka tentang berbagai tantangan dan bencana iklim dan non iklim yang utama di Setulang dan Malinau secara lebih luas, pemikiran mereka tentang strategi yang diterapkan saat ini untuk mengatasinya, dan masukan mereka tentang intervensi yang direkomendasikan.

\subsubsection{Bencana terkait iklim di Malinau}

Kecuali satu pemangku kepentingan tingkat kabupaten, semua menyatakan bahwa bencana terkait iklim telah menjadi ancaman di Malinau, karena meningkatnya dampak yang terkait dengan faktor-faktor penyebabnya maupun terkait frekuensi dan intensitas bencana.

Semua pemangku kepentingan memandang banjir sebagai masalah yang meluas di Malinau, dengan rerata 2000-4000 $\mathrm{mm}$ curah hujan setiap tahunnya. Banjir memengaruhi pola tanam dan hasil panen, transportasi, properti dan kesehatan. Namun, banjir dipandang sebagai kejadian yang normal, karena penduduk sudah terbiasa dengannya dan dampak yang parah disebabkan oleh kombinasi dari berbagai faktor (lihat bagian selanjutnya tentang hubungan berbagai bencana). Selain itu, banjir lebih dominan memengaruhi dataran rendah, sedangkan

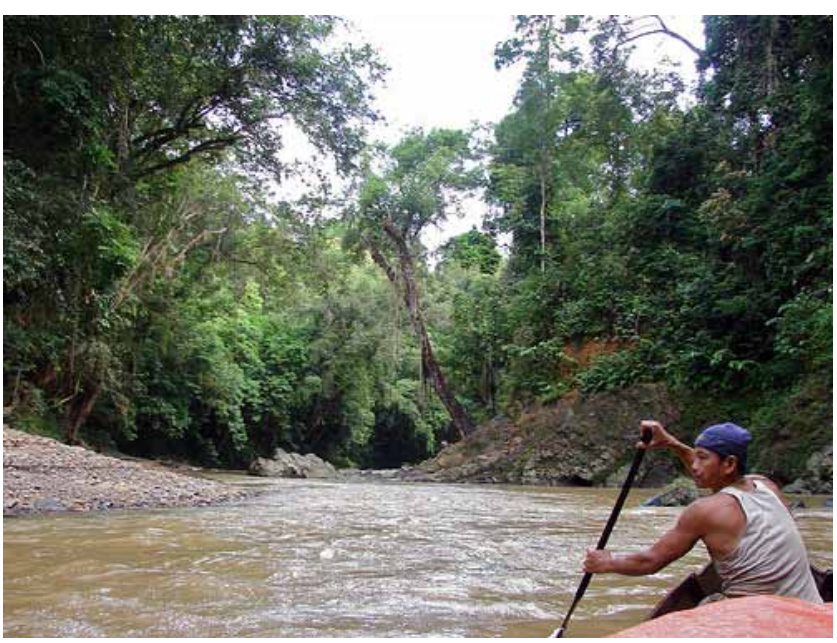

Gambar 7. Menyusuri Sungai Malinau

Sumber: Douglas Sheil/CIFOR

kekeringan dan pergeseran musim dianggap sebagai kekhawatiran yang lebih besar untuk tingkat kabupaten.

Kekeringan dirasakan sebagai fenomena yang relatif baru di Malinau. Masyarakat memperhatikan bahwa beberapa bulan yang biasanya basah hanya mengalami hujan yang sangat sedikit atau tidak sama sekali yang berdampak parah bagi penanggalan panen masyarakat. Sebagai contoh, persiapan lahan dan penanaman beras gogorancah (ladang) biasanya dilakukan pada bulan Agustus, bulan yang biasanya kemarau, sehingga hujan yang diprakirakan mulai bulan September dan sesudahnya dapat mengairi tanaman sesuai kebutuhan selama tahap perkembangan yang penting. Namun, beberapa tahun terakhir, Desember dan Januari justru selalu kemarau, yang menyebabkan kegagalan panen di Malinau. Perubahan lain yang terjadi adalah curah hujan yang lebih tinggi dari rerata selama musim kemarau.

Masyarakat setempat telah melaporkan penurunan jumlah buah yang tersedia, peningkatan intensitas dan frekuensi penyakit tanaman, dan semakin sulitnya perburuan binatang liar.

\subsubsection{Tantangan lain di Malinau}

Para pemangku kepentingan memandang tantangan yang tidak terkait iklim sebagai masalah terbesar, khususnya karena mereka memperbesar dampak iklim dan bencana lain. 
Pertambangan batu bara yang tidak berkelanjutan dan deforestasi merupakan isu yang paling sering diungkapkan. Banyak konsesi pertambangan yang tidak mengikuti praktik-praktik terbaik yang disarankan, dan kegiatan-kegiatan pertambangan yang dilakukan di hulu telah berpengaruh buruk bagi penduduk maupun flora dan fauna. Polusi sungai jelas telah menurunkan populasi ikan yang sebelumnya berlimpah namun sekarang sudah sulit dicari. Polusi air juga telah menyebabkan masalahmasalah kesehatan seperti penyakit kulit (juga disampaikan oleh masyarakat Setulang).

Meskipun terdapat masalah terkait pertambangan yang tidak berkelanjutan, jumlah konsesi pertambangan batu bara terus meningkat, demikian juga dengan permintaan atas lahan. Kondisi ini telah mendorong deforestasi meningkat dan semakin berkurangnya lahan yang tersedia untuk pertanian. Kombinasi deforestasi dan polusi dari pertambangan telah menyebabkan kualitas Sungai Malinau merosot dan sedimentasinya tingkat tinggi. Sejumlah masyarakat setempat yang tinggal di dataran rendah telah melaporkan kelangkaan air pada musim kemarau yang mereka kaitkan dengan pertambangan dan deforestasi di hulu.

Isu lain yang dibahas adalah kesulitan untuk mengembangkan padi sawah dan sawah beririgasi di daerah selain di dataran rendah. Sawah beririgasi umumnya dianggap lebih produktif dan tahan bencana seperti perubahan musim dan kekeringan. Namun demikian, mengembangkan sawah di daerah hulu adalah sesuatu yang mahal, sehingga perladangan berpindah tetap menjadi pilihan yang paling memungkinkan dan lebih disukai. Namun, untuk mempertahankannya akan lebih banyak lagi lahan yang dibutuhkan karena meningkatnya penduduk dan kompetisi pemanfaatan lahan.

Responden terbagi dalam hal hama dan penyakit tanaman (misalnya, hama wereng pada padi-juga dikenal sebagai wereng coklat) adalah masalah serius. Menurut beberapa responden, hama dan penyakit bukan ancaman utama karena terjadi pada skala kecil dan dapat diantisipasi. Selain itu, karena sawah di Malinau letaknya cukup tersebar, wabah hama dan penyakit dapat dengan mudah dicegah.

Namun, responden lainnya melaporkan kecenderungan peningkatan hama dan penyakit, termasuk belatung, hama padi (penyakit tunas kering dan layu), ulat dan wereng daun. Peningkatan jumlah serangan satwa liar hutan pada tanaman (misalnya, serangan monyet) juga menjadi kekhawatiran.

Hal ini terjadi karena sulitnya satwa tersebut mencari makanan di hutan karena perubahan pola pembungaan dan berkurangnya ketersediaan HHBK seperti kacang-kacangan.

Para pemangku kepentingan di tingkat kabupaten terlihat agak enggan untuk membahas konflik tenurial lahan: masalah ini dikatakan signifikan namun tidak dieksplorasi secara rinci. Tenurial lahan dan batas desa merupakan hal sangat sensitif dan keputusan mengenainya tidak mudah dilakukan, baik di dalam atau antarpemerintah kabupaten karena khawatir membuat marah masyarakat, memperburuk konflik yang ada atau memicu konflik tambahan. Proses penandaan batas-batas Desa Setulang dan Tane 'Olen oleh masyarakat Setulang dan LSM tidak diterima seluruhnya, hal ini karena penduduk Setulang dipandang sebagai pendatang yang relatif baru di daerah dan sebagian besar pemangku kepentingan di tingkat kabupaten merasa bahwa desa-desa yang lain belum cukup dipertimbangkan atau dikonsultasikan. Secara umum, penentuan batas wilayah desa dan perbatasan secara ketat, kaku dan kebanyakan dari atas ke bawah serta nonpartisipatif, dipandang sebagai penyebab mendasar dari konflik tenurial. Pemerintah daerah telah berusaha mengatasinya namun belum menindaklanjuti masalah-masalah yang mendasarinya.

Hal yang terkait erat dengan konflik tenurial adalah isu perencanaan tata guna lahan yang tidak tepat. Sebagian besar masalah di Malinau (misalnya, deforestasi) dapat disebabkan oleh kurang jelasnya rencana tata guna lahan. Kabupaten tidak memiliki rencana tata guna lahan yang sinergis, di mana perencanaan dibuat untuk keseluruhan kabupaten, berdasarkan komunikasi lintas sektoral antarinstansi dan selaras dengan kebijakan, serta memperhitungkan tujuan-tujuan pembangunan dan konservasi hutan yang sering bertentangan. Walaupun perencanaan spasial seharusnya dengan jelas menyediakan wilayah untuk produksi, perlindungan dan pertanian, perencanaan tata guna lahan dan pembangunan yang ada menyebabkan ketidakpastian dan kebingungan di antara para pemangku kepentingan. Kebijakan disusun tanpa pengamatan yang mendalam atas isu-isu yang saling terkait dan tidak ada usaha untuk menyeimbangkan konservasi hutan, pertumbuhan penduduk dan perluasan desa yang telah berlangsung selama ini. Masalah diperparah dengan dideklarasikannya 
Malinau sebagai sebuah kabupaten konservasi, namun ekplorasi pertambangan batu bara juga sedang berjalan bersamaan. Karena itu dibutuhkan kolaborasi yang lebih besar untuk menyeimbangkan imbal balik antara konservasi dan pembangunan.

\subsubsection{Hubungan antara berbagai tantangan}

Hampir semua responden di tingkat kabupaten menyoroti hubungan dan umpan balik antara tekanan-tekanan iklim dan non iklim, khususnya curah hujan tinggi, pertambangan, deforestasi dan banjir. Masyarakat Malinau biasanya bisa mengatasi tingginya curah hujan dengan baik, namun banjir telah diperparah oleh deforestasi di hulu dan kerusakan yang disebabkan oleh pertambangan batu bara. Jumlah konsesi pertambangan batu bara telah meningkat seiring dengan permintaan atas lahan yang menyebabkan meningkatnya deforestasi dan semakin berkurangnya lahan pertanian yang tersedia. Ditambah lagi polusi dan sedimentasi Sungai Malinau yang kesemuanya memperparah semua dampak ini. Kapasitas alami Sungai Malinau untuk menampung curah hujan berlebih telah sangat berkurang. Degradasi keseluruhan sungai juga disebutkan sebagai penyebab mendasar dari kerusakan karena banjir.

Masyarakat telah mengeluhkan dampak pertambangan batu bara serta polusi sungai, namun perusahaan pertambangan tidak mematuhi peraturan dan praktik-praktik pengelolaan buangan mereka sulit dikontrol. Sebaliknya, desa-desa yang berada di hulu, misalnya Loreh, memperolah keuntungan dari pertambangan batu bara dan telah menerima kompensasi dari perusahaan yang mengangkut batu bara melalui desa.

Hubungan lain yang disebutkan adalah kaitan antara kegagalan panen akibat kekeringan dan hampir tidak adanya fasilitas irigasi di wilayah perdesaan. Selain itu juga antara semakin sering terjadinya serangan hama dan penyakit, pergeseran musim dan penolakan penduduk desa terhadap praktik-praktik pertanian yang baru.

\subsubsection{Strategi saat ini dan yang disarankan untuk mengatasi sejumlah tantangan}

Sejumlah dinas di kabupaten sedang melaksanakan berbagai strategi atau telah menyarankan intervensi dalam rangka mengatasi beberapa bencana dan tantangan di Malinau (Tabel 4).
Dinas pertanian mencoba untuk mendorong praktikpraktik budidaya adaptif berdasarkan prakiraan iklim serta risiko hama dan penyakit. Penyuluh pertanian memberikan saran kepada para petani tentang pola penanaman yang optimal dan panen dua kali setahun (misalnya, menggunakan rotasi yang lebih pendek dan menanam jenis tanaman lain langsung setelah panen yang pertama). Namun, warga desa enggan untuk melakukannya karena khawatir akan meningkatkan risiko serangan hama mengingat akan tersedianya lebih banyak makanan bagi hama. Dinas penyuluhan, yang berfokus pada padi dan jagung, menyarankan untuk mengganti jenis tanaman yang ditanam setiap tahun (misalnya, padi satu tahun, berikutnya tanaman yang lain) sebagai sebuah jalan untuk menghindari hama dan penyakit. Mereka juga secara aktif mendorong sawah beririgasi untuk mengatasi kekeringan dan pergeseran musim. Namun demikian, masyarakat enggan mengubah pola tanam karena telah biasa dengan praktik-praktik budaya berabad lampau dan sawah beririgasi hanya bisa dikembangkan di daerah hilir. Keterbatasan lain dari dinas adalah karena alat pengukur hujan tidak tersedia di setiap kecamatan, sehingga pada beberapa kasus mereka harus menggunakan data tingkat provinsi dengan resolusi yang lebih kasar.

Dinas untuk pemberdayaan masyarakat berkutat dengan isu penghidupan sebagai prioritas masyarakat. Mereka menggunakan proses-proses dari bawah ke atas dan program pembangunan perdesaan insiatif dari pemerintah yaitu Gerakan Desa Membangun (Gerdema). Proyek ini di antaranya pengembangan usaha mikro kerajinan tangan bagi desa-desa yang tertarik mengikuti sesuai keahlian atau praktikpraktik budaya yang ada. Dinas juga mempekerjakan staf/penasihat (Satgas) teknis untuk membantu desa dan membangun kapasitas dalam melaksanakan intervensi Gerdema, khususnya dalam pengelolaan proyek dan keuangan. Tujuannya adalah agar masing-masing desa memiliki setidaknya satu Satgas dengan keahlian teknis (misalnya, pengelolaan atau keuangan) atau sosial, bergantung pada kebutuhan masing-masing.

Visi di balik Gerdema adalah untuk mencapai pemberdayaan perdesaan melalui proses dari bawah ke atas berdasarkan aspirasi masyarakat dan pengelolaan lingkungan hidup yang baik. Program ini berdasarkan pada prinsip pengelolaan lingkungan hidup yang baik bagi pembangunan. Keberhasilan program Gerdema bervariasi dari desa ke desa. Meskipun beberapa desa berjuang untuk melakukan transformasi ekonomi, infrastruktur yang ada sangat 
Tabel 4. Tantangan/bahaya dan strategi penanggulangan: responden tingkat kabupaten

\begin{tabular}{|c|c|c|c|}
\hline Instansi & $\begin{array}{l}\text { Tantangan/ } \\
\text { bahaya }\end{array}$ & Strategi penanggulangan/solusi & $\begin{array}{l}\text { Intervensi masa depan yang } \\
\text { disarankan }\end{array}$ \\
\hline Kehutanan & Deforestasi & $\begin{array}{l}\text { Melengkapi dan mengelola } \\
\text { permohonan/pengajuan Hutan Desa. }\end{array}$ & \\
\hline Pertanian & $\begin{array}{l}\text { Kekeringan } \\
\text { dan pergeseran } \\
\text { musim }\end{array}$ & $\begin{array}{l}\text { Memberi penyuluhan kepada petani } \\
\text { tentang pola-pola penanaman yang } \\
\text { optimal dan mendorong pemanenan dua } \\
\text { kali setahun. }\end{array}$ & \\
\hline Pertanian & $\begin{array}{l}\text { Hama dan } \\
\text { penyakit tanaman }\end{array}$ & & $\begin{array}{l}\text { Mendorong pergantian jenis-jenis } \\
\text { tanaman setiap tahunnya. }\end{array}$ \\
\hline $\begin{array}{l}\text { Pemberdayaan } \\
\text { masyarakat }\end{array}$ & $\begin{array}{l}\text { Kurangnya } \\
\text { pemberdayaan }\end{array}$ & $\begin{array}{l}\text { Mempekerjakan staf teknis di desa untuk } \\
\text { membantu merencanakan kegiatan } \\
\text { di bawah program pemberdayaan } \\
\text { masyarakat Gerdema. }\end{array}$ & \\
\hline $\begin{array}{l}\text { Badan } \\
\text { Perencanaan } \\
\text { dan }\end{array}$ & Deforestasi & & $\begin{array}{l}\text { Perancanaan tata guna lahan } \\
\text { terpadu dengan kerja sama } \\
\text { antarinstansi. }\end{array}$ \\
\hline $\begin{array}{l}\text { Pembangunan } \\
\text { Daerah } \\
\text { (Bappeda) }\end{array}$ & & & $\begin{array}{l}\text { Devolusi pengelolaan hutan } \\
\text { kepada masyarakat karena mereka } \\
\text { adalah pengelola ekosistem yang } \\
\text { terbaik. }\end{array}$ \\
\hline Perkebunan & $\begin{array}{l}\text { Kurangnya } \\
\text { diversifikasi }\end{array}$ & $\begin{array}{l}\text { Mendorong budidaya kelapa sawit, kakao } \\
\text { dan karet. }\end{array}$ & \\
\hline \multirow{2}{*}{$\begin{array}{l}\text { Kantor Taman } \\
\text { Nasional Kayan } \\
\text { Mentarang }\end{array}$} & \multirow{2}{*}{$\begin{array}{l}\text { Konflik tenurial } \\
\text { (pengecualian } \\
\text { dari hutan) }\end{array}$} & $\begin{array}{l}\text { Melibatkan masyarakat dalam konservasi } \\
\text { dan pengelolaan taman. }\end{array}$ & \multirow{2}{*}{$\begin{array}{l}\text { Memberikan hak pengelolaan. } \\
\text { Tane' Olen kepada masyarakat } \\
\text { yang terkena dampak. }\end{array}$} \\
\hline & & $\begin{array}{l}\text { Menjelaskan tentang pemanfaatan hasil } \\
\text { hutan dan zonasi taman. }\end{array}$ & \\
\hline $\begin{array}{l}\text { Lingkungan } \\
\text { hidup }\end{array}$ & Polusi sungai & $\begin{array}{l}\text { Mengeluarkan izin untuk operasi } \\
\text { pertambangan agar mengatur } \\
\text { pengelolaan limbah. }\end{array}$ & \\
\hline $\begin{array}{l}\text { Lingkungan } \\
\text { hidup }\end{array}$ & Banjir & $\begin{array}{l}\text { Meningkatkan kesadaran masyarakat } \\
\text { tentang pengelolaan limbah dan pohon } \\
\text { yang tepat. }\end{array}$ & \\
\hline WWF Malinau & $\begin{array}{l}\text { Kurangnya } \\
\text { diversifikasi }\end{array}$ & $\begin{array}{l}\text { Mendorong kelompok tani dan koperasi, } \\
\text { pembimbingan, pengembangan } \\
\text { produksi organik dan ekoturisme. }\end{array}$ & \\
\hline
\end{tabular}

buruk sehingga mereka tidak dapat mencapainya tanpa investasi berskala lebih besar; dalam kasus ini fokusnya bergeser ke budidaya dan mengelola sumber daya untuk konsumsi rumah tangga (subsisten).

Perhatian utama Bappeda, Badan Perencanaan dan Pembangunan Kabupaten, adalah untuk menyatukan konservasi dengan pembangunan, yang hanya dapat tercapai melalui perencanaan tata guna lahan yang lebih kooperatif, saksama dan multisektoral. Bappeda meyakini bahwa masyarakat seharusnya diberi tanggung jawab untuk pengelolaan hutan, karena mereka akan menjadi pengelola hutan yang lebih baik dibandingkan pemerintah atau sektor swasta sehingga akan membantu menghentikan deforestasi.
Dinas perkebunan, di bawah arahan pemerintah pusat berfokus pada kelapa sawit, kakao dan karet. Kakao khususnya telah dikembangkan sampai tingkat tertentu dan memiliki prospek dan hasil investasi yang baik. Selain itu, layanan penyuluhannya telah dikembangkan dengan baik dan masyarakat sudah akrab dengan pengelolaannya. Sebaliknya, kopi memiliki masalah karena bibit impor yang digunakan menghasilkan panen dengan rasa yang asam. Dinas telah melakukan beberapa percontohan untuk kopi dan tanaman untuk perdagangan lain, namun menghadapi kendala keterbatasan pengalaman lapangan sejumlah staf dan penolakan dari masyarakat. Belum ada lokasi percontohan yang dikembangkan untuk karet, namun ada rencana untuk dilakukan 
dalam waktu dekat. Masyarakat juga menyarankan budidaya produk lain seperti buah, yang sangat sesuai untuk program diversifikasi mata pencaharian karena buah mudah dipasarkan dan masyarakat tahu bagaimana mengelolanya.

Kantor Taman Nasional Kayan Mentarang telah bermaksud untuk mengurangi konflik yang terkait dengan perlindungan hutan pada lahan masyarakat dengan memberikan hak pemanfaatan dan pengelolaan atas Tane' Olen kepada masyarakat. Sebelum mendapatkan status sebagai taman nasional pada 1996, Kayan Mentarang adalah sebuah cagar alam, yang berarti bahwa masyarakat tidak dapat mengakses hutan atau hasilnya, sebuah situasi yang mendorong konflik. Konsep Tane' Olen (penduduk desa melindungi hutan dengan hukum adat) dapat diterapkan pada wilayah di luar Setulang, namun program seharusnya secara aktif merangkul kaum muda. Kantor Taman Nasional Kayan Mentarang mengelola beberapa program konservasi dan pengelolaan bersama masyarakat, khsusnya dengan para pemudanya. Mereka juga memberikan saran tentang pemanfaatan dan pengelolaan kayu bakar, zonasi di dalam kawasan dan fungsi taman nasional.

Dinas lingkungan hidup telah mencoba untuk memperketat peraturan yang mengatur operasi pertambangan dan pengelolaan buangan dengan mengeluarkan izin yang membatasi jumlah limbah yang boleh dibuang ke sungai. Sebuah tim antardinas bekerja bersama anggota masyarakat untuk mengawasi operasi pertambangan dan membatasi polusi.

Pembuangan sampah dari masyarakat ke sungai merupakan isu utama juga. Dinas telah memulai sebuah program pengumpulan sampah, bekerja sama dengan Bagian Perencanaan Tata Kota. Untuk membantu menekan dampak banjir, sejumlah dinas lain juga melaksanakan pekerjaan teknis seperti pengerukan dan penanganan konstruksi di sepanjang pinggir sungai, sementara dinas lingkungan hidup juga berupaya untuk mendidik masyarakat tentang pengelolaan sampah (misalnya, pembuangan yang tepat untuk menghindari penyumbatan saluran air dan sungai) dan pengelolaan pohon (misalnya, mendidik masyarakat tentang mengapa mereka tidak boleh menebang pohon di atau sekitar tepi sungai dan mendorong penanaman pohon). Namun demikian, dinas mengalami kesulitan untuk mengakses desadesa di pelosok dan untuk mendapatkan informasi detil tentang sejumlah tantangan tertentu. Meskipun memiliki petugas yang ditempatkan di sekitar desa memungkinkan untuk mendapatkan informasi yang cepat tentang bencana-bencana lingkungan (misalnya, pembuangan sampah di sungai) dan mendorong penanganan masalah dengan tepat waktu, tidak ada sumber daya untuk melakukannya.

WWF Malinau berfokus mendorong masyarakat untuk membentuk kelompok tani (misalnya, di Krayan) untuk lebih mengembangkan dan memasarkan komoditas lokal. Program pembimbingan telah diperkenalkan untuk penguatan kelembagaan koperasi, pengembangan dan sertifikasi produk organik dan ekowisata di beberapa desa di sekitar Taman Nasional Kayan Mentarang. LSM ini menganggap pengembangan pertanian organik dan wanatani sebagai strategi penting untuk membantu masyarakat beradaptasi dengan perubahan iklim.

\subsubsection{Tantangan di Setulang}

Responden tingkat kabupaten menganggap tidak ada tantangan besar di Setulang, kecuali konflik sosial yang terkait tenurial. Desa ini dianggap dalam kondisi yang lebih baik dibandingkan desa lain di kabupaten dan terdapat kekhawatiran jika fokus terus-menerus di Setulang akan membuat desa lain iri dan memperparah konflik. Kebanyakan responden di tingkat kabupaten meyakini bahwa LSM-LSM lebih membela Setulang dalam upayaupaya konflik resolusi sebelumnya sementara desadesa lain diabaikan. Para pemangku kepentingan setempat memandang hal ini tidak adil, mengingat penduduk Setulang relatif penghuni baru di wilayah tersebut dan bahwa desa-desa lain tidak cukup diajak berunding selama delineasi Tane' Olen dan batas wilayah desa. Terdapat kesepakatan umum bahwa konflik ini merupakan masalah serius karena membatasi pengembangan lebih lanjut lahan pertanian, tidak hanya di Setulang tapi juga di desa sekitarnya.

Kurangnya lahan yang tersedia merupakan masalah yang mungkin terjadi di masa mendatang untuk Setulang. Lebih dari setengah wilayah desa berada di dalam status kawasan konservasi dan sisanya disisihkan untuk pertanian, perumahan dan fasilitas, sementara yang terus bertambah akan mengalami kesulitan dengan tata guna lahan dan perluasan desa, terutama jika konflik dengan desa-desa tetangga tidak diselesaikan. 


\section{Analisis Iklim dan Kerentanan}

\subsection{Paparan}

\subsubsection{Tren iklim masa lalu dan kini di Malinau}

\section{Iklim rerata di Malinau}

Musim rerata di Malinau lebih rendah daripada di wilayah lain dengan iklim serupa. Artinya, rerata musim (baik panas/dingin atau kering/basah) tidak berbeda sangat jauh. Rerata suhu bulanan berkisar dari $26,4^{\circ} \mathrm{C}$ sampai $27,3^{\circ} \mathrm{C}$ dan curah hujan $205-360$ $\mathrm{mm} /$ bulan (Gambar 8).

Data variabilitas iklim tahunan menunjukkan bahwa Indonesia terbagi dalam tiga wilayah curah hujan. Malinau termasuk dalam karakteristik wilayah B, dengan iklim ekuatorial dan dua puncak curah hujan, yaitu pada bulan Oktober-November dan MaretMei (Aldrian dan Susanto 2003). Kedua puncak ini berkaitan dengan pergerakan ke arah selatan dan utara dari zona konvergen antartropis. Walaupun secara tradisional tidak disebutkan adanya musim kemarau, telah terjadi kekeringan yang semakin meningkat frekuensinya (Hilman dkk. 2010).

\section{Variabilitas antartahun dan tren curah hujan dan suhu}

Data iklim masa lampau mengindikasikan variabilitas curah hujan antartahun relatif normal: 55\% lokasi beriklim serupa di dunia (dengan $\pm 1^{\circ} \mathrm{C}$ suhu rerata tahunan dan $\pm 10 \%$ curah hujan tahunan) memiliki variabilitas antartahun yang lebih rendah (atau $45 \%$ memiliki variabilitas antartahun yang lebih tinggi). Terdapat tahun-tahun yang lebih kering atau lebih basah tapi deviasi ini tidak dianggap sebagai pengecualian. Lima tahun dengan curah hujan paling rendah sejak 1960 adalah 1964, 1965, 1967, 1992 dan 1997, dan lima tahun dengan curah hujan paling tinggi adalah 1962, 1974, 1980, 1988 dan 1999. Terlihat bahwa terdapat tren meningkatnya curah hujan (garis tebal hitam pada Gambar 9), meski tidak signifikan.

Variabilitas suhu antartahun juga termasuk normal: $58 \%$ lokasi dengan iklim yang sama memiliki variabilitas antartahun yang lebih rendah (atau 42\% memiliki variabilitas antartahun yang lebih tinggi). Lima tahun dengan suhu terendah adalah tahun

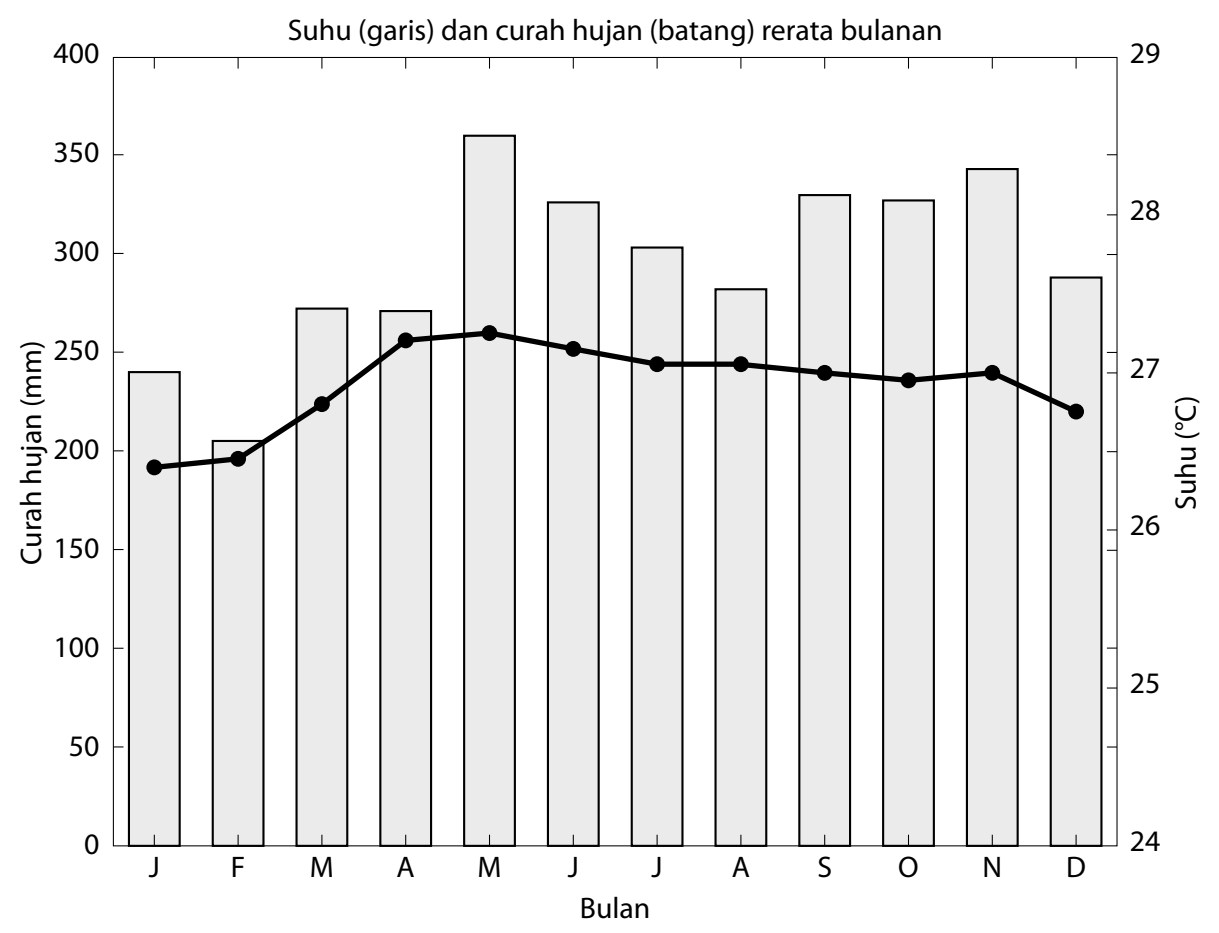

Gambar 8. Iklim rerata di Malinau 


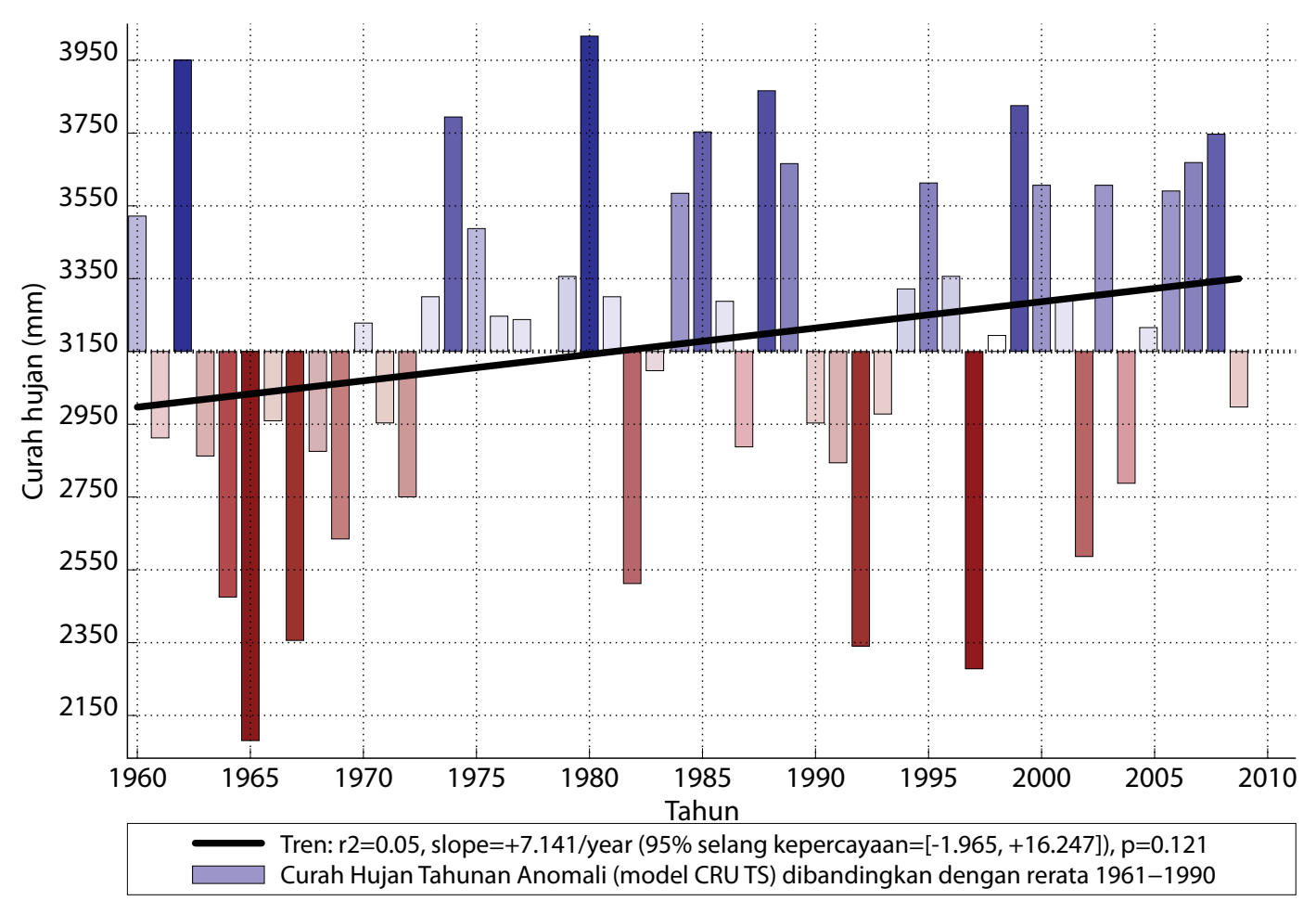

Gambar 9. Variabilitas curah hujan tahunan di Malinau (1960-2010)

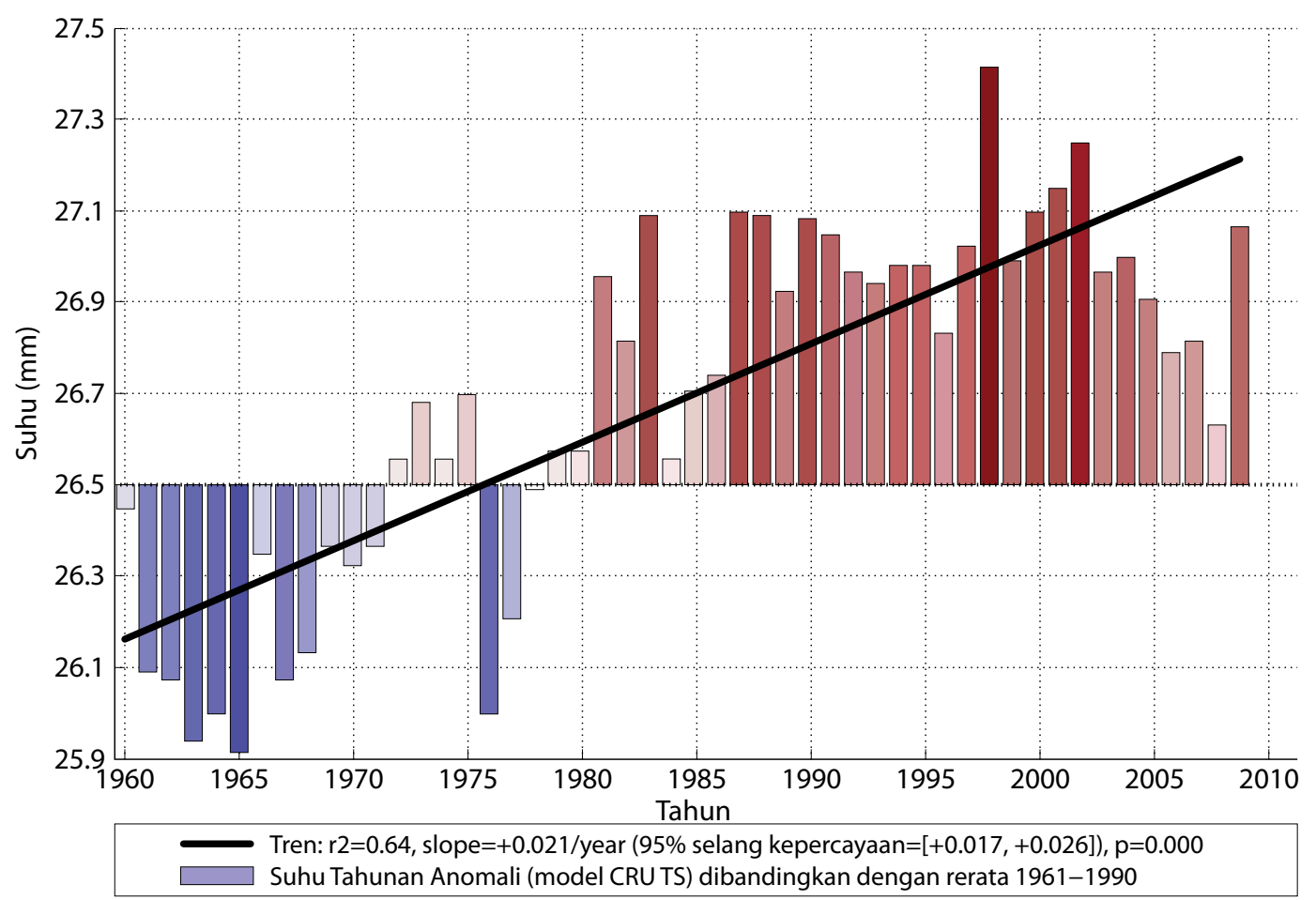

Gambar 10. Variabilitas suhu tahunan di Malinau (1960-2010) 
1962, 1963, 1964, 1965 dan 1976, dan lima tahun dengan suhu tertinggi adalah tahun 1987, 1998, 2000, 2001 dan 2002. Terlihat jelas adanya tren peningkatan suhu yang signifikan (Gambar 10).

\subsubsection{Proyeksi tren iklim masa depan}

\section{Curah hujan di masa depan di Malinau}

Seperti di sebagian besar wilayah tropis, curah hujan masa depan di Malinau sangat tidak pasti (Gambar 11). Bergantung pada skenario GCM dan emisi, curah hujan rerata tahunan bisa jadi akan meningkat atau menurun. Secara umum, delapan skenario menunjukkan adanya peningkatan, sedangkan delapan yang lain menunjukkan penurunan. Peningkatan maksimum yang diproyeksikan pada 2020 adalah $38,18 \mathrm{~mm} /$ tahun (dengan skenario csiro2.b1a), sedangkan penurunan maksimum adalah $62,80 \mathrm{~mm} /$ tahun (skenario $\mathrm{cgcm}$ 2.a1fi). Peningkatan maksimum yang diproyeksikan pada 2050 adalah $83,19 \mathrm{~mm} /$ tahun (skenario csiro2.a1a), sedangkan penurunan adalah 154,76 mm/tahun (skenario cgcm2.a1fi). Peningkatan maksimum yang diproyeksikan pada 2080 adalah $152.00 \mathrm{~mm} /$ tahun (skenario csiro2. a1a), dan penurunan maksimum yang diproyeksikan adalah $280,83 \mathrm{~mm} /$ tahun (skenario $\mathrm{cgcm} 2 . a 1 \mathrm{f}$ ).

Kekhawatiran lain justru muncul terkait dengan tahun-tahun basah atau kering yang ekstrem (variabilitas antartahun) dan kejadian-kejadian ekstrem dibanding tentang curah hujan rerata tahunan masa depan pada 2020, 2050 dan 2080. Namun, model-model iklim tidak melakukan simulasi variabilitas antartahun dengan baik.

Rerata curah hujan bulanan masa depan yang sangat penting untuk menentukan pola tanam juga tidak pasti (Gambar 12). Rerata ini tidak terlalu informatif, namun kondisi ekstremnya (peningkatan dan penurunan maksimum) dapat digunakan sebagai masukan untuk rancangan strategi yang tangguh.

\section{Proyeksi suhu tahunan di Malinau}

Tren suhu tahunan rerata masa depan di Malinau lebih pasti (Gambar 13). Semua model menunjukkan kenaikan suhu sebagai berikut:

- minimal $0,45^{\circ} \mathrm{C}$ (dengan skenario pcm.b1 memprediksi kenaikan terendah) sampai $0,87^{\circ} \mathrm{C}$

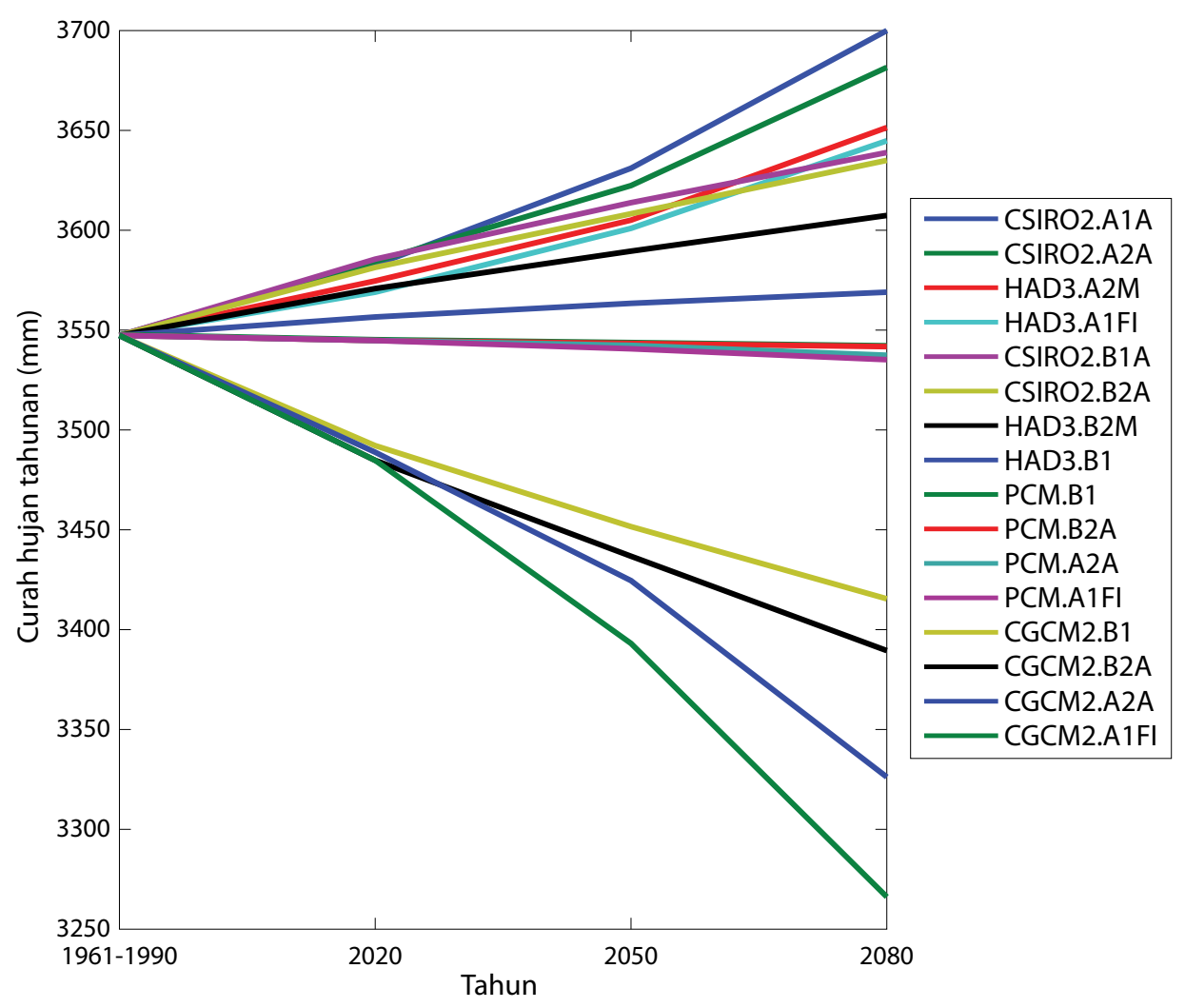

Gambar 11. Curah hujan tahunan di Malinau pada 2020, 2050 dan 2080, berdasarkan 16 skenario iklim 


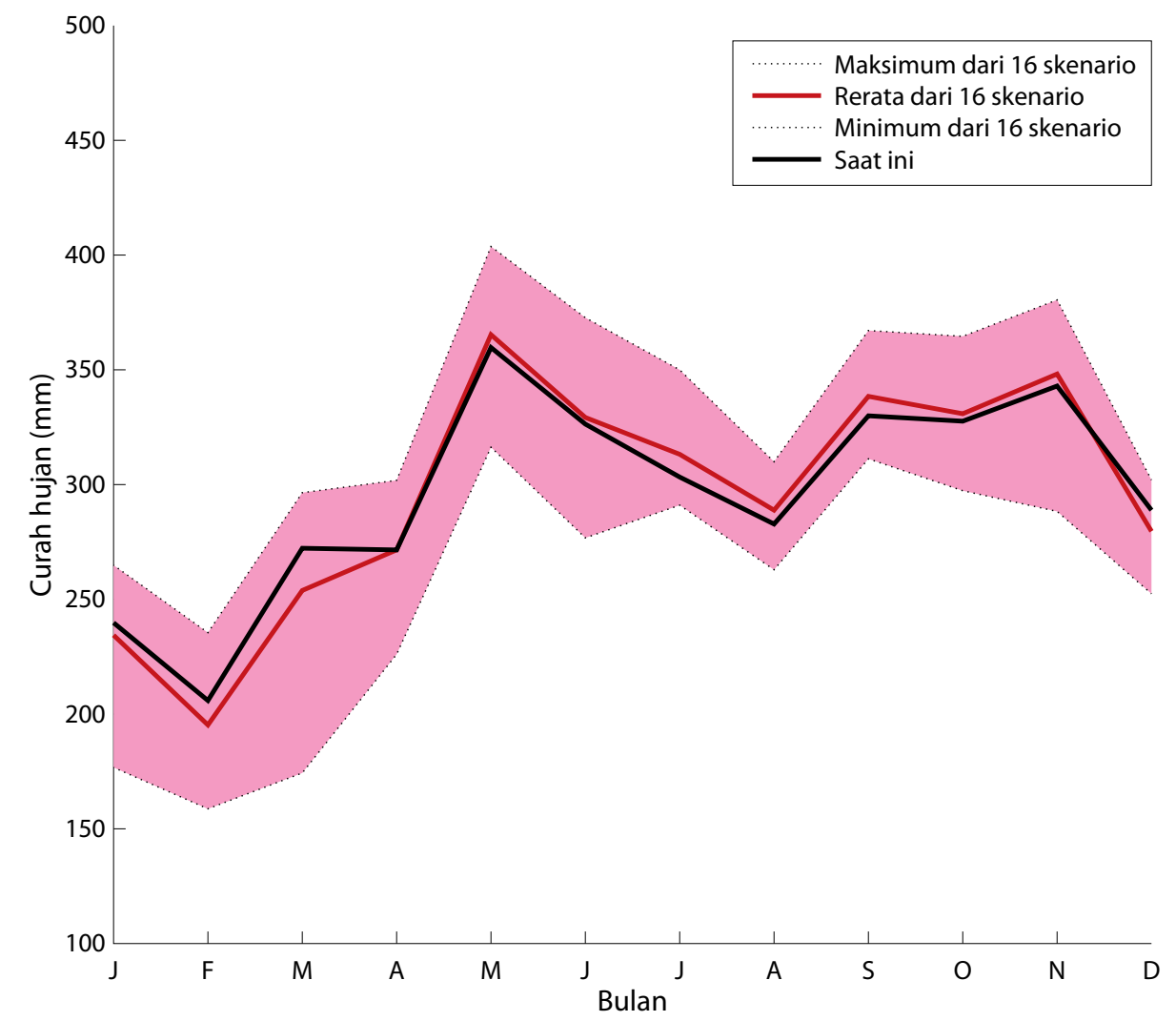

Gambar 12. Prakiraan curah hujan bulanan di Malinau untuk 2080

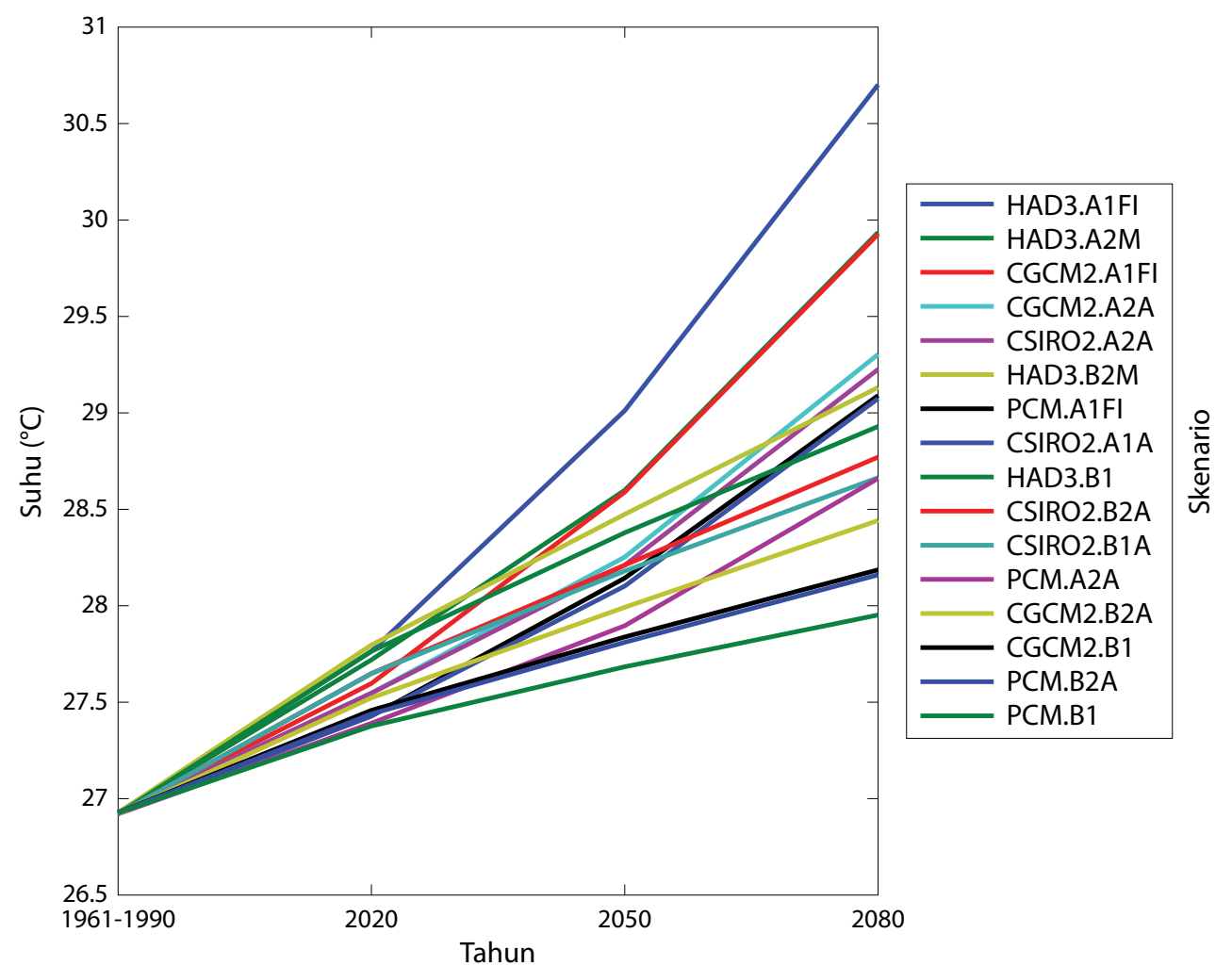

Gambar 13. Suhu rerata di Malinau pada 2020, 2050 dan 2080, berdasarkan 16 skenario iklim 
(dengan skenario had3.b2m memprediksi kenaikan tertinggi) pada tahun 2020;

- setidaknya $0,76^{\circ} \mathrm{C}$ (pcm.b1) sampai maksimum $2,08^{\circ} \mathrm{C}$ (had3.alfi) pada tahun 2050;

- setidaknya $1,03^{\circ} \mathrm{C}$ (pcm.b1) sampai maksimum $3,77^{\circ} \mathrm{C}$ (had3.a1fi) pada tahun 2080.

Peningkatan ini menjadi kekhawatiran untuk Malinau, khususnya mengingat variabilitas suhu antartahun yang rendah di masa lampau (sekitar $2^{\circ} \mathrm{C}$ perbedaan suhu tahunan antara tahun terpanas dan tersejuk pada 25 tahun terakhir). Gelombang panas dan peningkatan suhu maksimum dan minimum harian ini menjadi perhatian utama.

\section{Kejadian-kejadian ekstrem}

Terdapat konsensus ilmiah bahwa perubahan iklim meningkatkan peluang terjadinya beberapa jenis kejadian ekstrem, seperti kekeringan dan gelombang panas (Field dkk. 2012; Peterson dkk. 2012). Namun karena sifat variabilitas iklim alami, sulit untuk memprakirakan apakah peluang ini akan meningkat setiap tahunnya dan jika benar demikian, seberapa besar peningkatannya (Peterson dkk. 2012). Namun yang jelas perubahan iklim akan semakin membuat kejadian-kejadian ekstrem ini tidak dapat diprediksi. Selain itu pola, intensitas serta lokasinya kemungkinan akan bergeser.

\section{Osilasi El Niño Selatan}

Kejadian Osilasi El Niño Selatan (ENSO) diprakirakan akan menyebabkan kekeringan dan curah hujan yang lebih ekstrem dengan adanya perubahan iklim. ENSO terjadi bergantian antara El Niño and La Niña. Selama tahun-tahun El Niño, air hangat yang tidak biasa terbentuk di sepanjang sebagian besar bagian timur dan tengah tropis di Pasifik yang menyebabkan penurunan curah hujan drastis di Asia Tenggara. La Nińa adalah kebalikan El Niño: tahun La Niña ditandai dengan suhu permukaan laut yang lebih dingin dari normal di wilayah timur dan tengah katulistiwa Pasifik, mengakibatkan curah hujan yang intens (IRI 2007). ENSO adalah hal yang normal dari iklim bumi (ENSO adalah bagian yang paling dominan dari daur variabilitas iklim selama rentang waktu subdekade) dan telah terjadi selama ratusan tahun (Yeh, dkk. 2009). Terjadinya El Niño yang berurutan tidak teratur, tetapi kecenderungannya terjadi setiap 2-4 tahun (periode osilasi frekuensi tinggi) atau setiap 4-6 tahun (frekuensi rendah) (An dan Wang 2000). Jika terjadi La Niña sering diikuti oleh El Nino dan sebaliknya, meskipun tidak selalu. ENSO berlangsung selama sekitar satu tahun, meskipun kadang-kadang dapat bertahan selama 18 bulan atau lebih (IRI 2007).

Aldrian dan Susanto (2003) mencatat bahwa selama kejadian El Niño 1997/1998, secara umum keseluruhan negara mengalami curah hujan di bawah persentil ke-10. Hendon (2003) menggunakan rerata data seri curah hujan dari rerata 43 stasiun curah hujan, menyimpulkan bahwa curah hujan di Indonesia adalah koheren dan terkait erat dengan variasi ENSO di kawasan Pasifik.

Walaupun frekuensi kejadian ENSO di masa depan dengan adanya perubahan iklim tidak dapat diprediksi secara akurat, beberapa analisis menunjukkan bahwa ENSO cenderung untuk mengalami transisi dari suatu perilaku osilasi yang stabil ke suatu osilasi yang tidak stabil dengan perubahan amplitudo, struktur dan frekuensi (Timmermann 2001). Beberapa proyeksi mengindikasikan bahwa kejadian ENSO hanya akan berlangsung pada frekuensi tinggi (setiap 2-3 tahun) setelah 2050 (Sofian 2010). Ketidakstabilan osilasi ini juga telah tercatat pada data yang terekam dari tahun 1980 dan sesudahnya yang menunjukkan kejadian ENSO yang lebih sering dan intens (IRI 2007).

\subsection{Sensitivitas}

\subsubsection{Produksi pertanian}

\section{Padi}

Semua padi, baik dari sawah tadah hujan maupun irigasi, sensitif terhadap sejumlah variabel iklim termasuk curah hujan, tekanan uap, kelembaban tanah, suhu musiman, suhu maksimum dan minimum harian, radiasi matahari dan tambahan tahunan dari konsentrasi karbondioksida $\left(\mathrm{CO}_{2}\right)$ atmosfer (Lansigan dkk. 2000; Wassmann dkk. 2009). Baik perubahan iklim jangka panjang dan variabilitasnya (misalnya, kenaikan suhu rerata tahunan) maupun kejadian cuaca jangka pendek (misalnya, kekeringan) memengaruhi produktivitas dan hasil padi. Pengaruh kejadian ekstrem jangka pendek dan ekstrem terhadap hasil panen sebagian besar bergantung pada tingkat pertumbuhan tanaman saat terjadinya paparan, di mana panenan dari sawah tadah hujan umumnya lebih sensitif dibandingkan panenan dari sawah beririgasi (Lansigan dkk. 2000). 
Peningkatan $\mathrm{CO}_{2}$ memiliki beberapa efek positif bagi produktivitas dan panenan padi, namun efek ini akan dikalahkan oleh dampak negatif kenaikan suhu (Baker dkk. 1992). Suhu optimum untuk sebagian besar tahap-tahap pertumbuhan padi adalah pada rentang antara $25-30^{\circ} \mathrm{C}$ (Tabel 5).

Walaupun suhu rerata tahunan di Malinau tidak diproyeksikan untuk naik di atas $30,5^{\circ} \mathrm{C}$, skenario hanya mengindikasikan rerata dari semua bulan dalam satu tahun dan suhu harian minimum dan maksimum. Apabila peningkatan sebesar nilai rerata ini diprakirakan akan terjadi, peningkatan nilai minimum dan maksimum harian hampir pasti terjadi, khususnya selama gelombang panas, kekeringan dan kejadian El Niño. Suhu harian maksimum dapat meningkat di atas $35^{\circ} \mathrm{C}$.

Suhu tinggi menyebabkan kemandulan tanaman padi selama proses-proses fisiologis yang sangat sensitif seperti pematangan dini dan terjadinya pembuahan awal. Proses pembungaan padi juga sangat sensitif terhadap suhu tinggi, dan pembukaan anak bulir selama periode pembungaan dapat sangat terpengaruh pada durasi paparan (Wassmann dkk. 2009).

Suhu tinggi juga memengaruhi fase pematangan, dengan memengaruhi proses-proses seluler dan perkembangan yang akhirnya menyebabkan

Tabel 5. Suhu kritis untuk pengembangan padi pada tahapan pertumbuhan yang berbeda

\begin{tabular}{|c|c|c|c|}
\hline \multirow{2}{*}{$\begin{array}{l}\text { Tahapan } \\
\text { Pertumbuhan }\end{array}$} & \multicolumn{3}{|c|}{ Suhu kritis $\left({ }^{\circ} \mathrm{C}\right)$} \\
\hline & Rendah & Tinggi & Optimum \\
\hline Perkecambahan & $16-19$ & 45 & $18-40$ \\
\hline $\begin{array}{l}\text { Munculnya bibit } \\
\text { ke permukaan } \\
\text { tanah }\end{array}$ & 12 & 35 & $25-30$ \\
\hline $\begin{array}{l}\text { Pembentukan } \\
\text { akar }\end{array}$ & 16 & 35 & $25-28$ \\
\hline $\begin{array}{l}\text { Pemanjangan } \\
\text { daun }\end{array}$ & $7-12$ & 45 & 31 \\
\hline $\begin{array}{l}\text { Pembentukan } \\
\text { anakan }\end{array}$ & $9-16$ & 33 & $25-31$ \\
\hline $\begin{array}{l}\text { Inisiasi bunga/ } \\
\text { primordia }\end{array}$ & 15 & - & - \\
\hline Pemisahan bunga & $15-20$ & 30 & - \\
\hline Pemekaran bunga & 22 & $35-36$ & $30-33$ \\
\hline Pematangan & $12-18$ & $>30$ & $20-29$ \\
\hline
\end{tabular}

penurunan kesuburan dan kualitas buliran (Barnabás dkk. 2008). Termasuk dalam pengaruh umum paparan selama fase ini adalah penurunan ukuran dan berat buliran, pengurangan isi buliran, persentase beras berkapur dan berwarna keputihan yang lebih tinggi, kesemuanya dapat mengurangi harga beras yang dihasilkan petani (Wassmann dkk. 2009).

Padi sangat sensitif terhadap peningkatan suhu minimum harian (suhu malam hari). Studi di Nepal menunjukkan bahwa peningkatan suhu minimum harian lebih berisiko dibandingkan peningkatan suhu maksimum harian untuk memperoleh panen beras besar (Rai dkk. 2012). Di Filipina, panenan buliran menunjukkan penurunan sampai $10 \%$ untuk setiap peningkatan suhu minimum sebesar $1^{\circ} \mathrm{C}$ pada musim tanam selama periode masa tanam kering (Peng dkk. 2004).

Tanaman padi juga sensitif terhadap variabilitas jumlah dan distribusi curah hujan. Di dataran tinggi yang dialiri, tekanan kelembaban sangat merusak atau bahkan membunuh tanaman padi di areal yang menerima $200 \mathrm{~mm}$ curah hujan dalam 1 hari dan kemudian tanpa curah hujan dalam 20 hari ke depan (Nguyen tanpa tahun). Banjir juga menjadi kendala dalam produksi padi di dataran rendah. Air yang berlebihan pada tahap pertumbuhan vegetatif menghambat perakaran dan menurunkan produksi anakan. Meskipun padi adalah tanaman semi akuatik, umumnya tidak tahan jika tergenang keseluruhan dan tanaman mati dalam beberapa hari jika benar-benar tenggelam (Wassmann dkk. 2009). Kebanyakan varietas padi bisa tahan jika tergenang seluruhnya selama sekitar 6 hari sebelum $50 \%$ dari tanaman mati. Angka kematian naik sampai 100\% saat genangan berlangsung selama 14 hari atau lebih, meskipun beberapa varietas dapat bertahan pada ambang 14 hari (Nguyen tanpa tahun; Wassmann dkk. 2009).

Di sisi lain, kekeringan selama pembukaan juga menyebabkan mandulnya anak bulir dan kehilangan panen utama (O'Toole dan Namuco 1983; Ekanayake dkk. 1989; Wassmann 2009). Kekurangan air tanah secara umum memengaruhi proses-proses fisiologis pada pertumbuhan dan perkembangan tanaman padi (Wassmann dkk. 2009). Kekeringan sebagai kendala utama produksi padi pada sistem tadah hujan ini memengaruhi 10 juta ha sawah di dataran tinggi dan lebih dari 13 juta ha sawah di dataran rendah tadah hujan di Asia (Pandey dkk. 2007). 
ENSO yang lebih sering dan intens, berkaitan dengan El Niño dan La Niña, dapat berdampak serius bagi produksi padi karena peningkatan kekeringan, suhu atau curah hujan tinggi dan banjir. Insiden hama dan penyakit juga akan semakin intensif oleh fluktuasi variabel-variabel iklim (Lansigan dkk. 2000). Studi di Indonesia telah menunjukkan bahwa wilayah padi yang terkena dampak wereng cenderung meningkat secara signifikan selama curah hujan panjang pada tahuntahun La Niña (Susanti dkk. 2010).

\section{Tanaman umbi-umbian}

Walaupun suhu optimum untuk singkong (Manihot esculenta) berada pada kisaran $22-32^{\circ} \mathrm{C}$ (Lebot 2009; Jarvis dkk. 2012), tanaman umbi-umbian khususnya toleran pada suhu tinggi dan kekeringan. Tumbuhan ini dapat bertahan hidup pada suhu hingga $45^{\circ} \mathrm{C}$ dan rerata curah hujan tahunan $300 \mathrm{~mm}$ (Jarvis dkk. 2012) namun tidak toleran terhadap genangan air (Lebot 2009). Selain itu, singkong sangat rentan terhadap hama dan penyakit (Herrera Campo dkk. 2011). Empat kendala biotik utama pada produksi singkong adalah lalat putih, wereng hijau singkong, penyakit mosaik singkong dan penyakit brown streak pada singkong, dengan wabah hama dan penyakit terjadi di sebagian besar Asia Tenggara (Herrera Campo dkk. 2011). Suhu yang lebih tinggi sangat mungkin menyebabkan meningkatnya wabah, sehingga membutuhkan pengelolaan hama dan penyakit yang sungguh-sungguh agar singkong dapat tumbuh dengan baik selama perubahan iklim (Ceballos dkk. 2011; Jarvis dkk. 2012).
Seperti singkong, ubi jalar (Ipomoea batatas) bersifat resisten terhadap kekeringan dan dapat tumbuh pada kondisi yang sulit dengan tanah yang buruk (Lebot 2009). Tanaman ini sangat toleran terhadap gulma dan memiliki relatif sedikit musuh. Namun demikian, ubi jalar lebih tidak toleran terhadap genangan air dibandingkan singkong dan perlu dipanen dan disimpan sebelum mulai hujan lebat (Lebot 2009). Peningkatan curah hujan tahunan dan seringnya hujan lebat akan membuat budidaya ubi jalar menjadi sulit.

\section{Tanaman penting lainnya}

Pisang, yang dibudidayakan di sebagian besar wilayah Indonesia, memerlukan air yang cukup yang secara merata sepanjang tahun dan tumbuh optimal pada kisaran suhu $24-27^{\circ} \mathrm{C}$ (Jarvis dkk. 2012). Suhu di luar kisaran ini mengganggu pertumbuhan dan perkembangannya (Gambar 14). Penelitian menunjukkan bahwa tanaman mengalami kerusakan karena panas pada suhu minimum (malam) dan maksimum (siang) harian yaitu pada $30^{\circ} \mathrm{C}$ dan $37^{\circ} \mathrm{C}$ secara berturut-turut (Turner dan Lahav 1983). Suhu tinggi menyebabkan jumlah unit daun yang lebih sedikit dan adanya bagian yang kurang kering pada akar dan kalus dibandingkan dengan tanaman yang tumbuh di bawah suhu minimum/maksimum harian yang optimal yaitu $18 / 25^{\circ} \mathrm{C}$. Secara umum, produktivitas dan hasil mulai menurun di atas suhu optimum $27^{\circ} \mathrm{C}$ (Sastry 1988). Tanaman ini juga sangat sensitif terhadap hama dan penyakit, yang mungkin menjadi lebih parah dengan perubahan iklim.

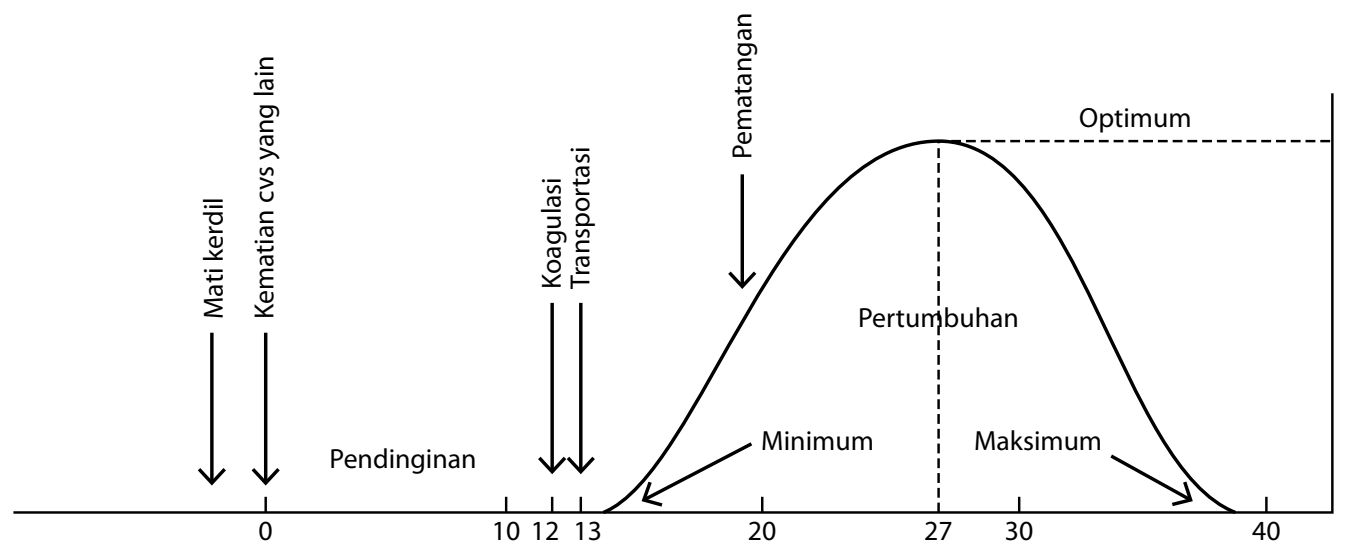

Gambar 14. Hubungan antara suhu dan pertumbuhan pisang Sumber: Sastry (1988) 
Tanaman lain yang dibudidayakan di Malinau adalah jagung, kakao dan kopi dalam jumlah yang lebih sedikit (Sheil 2002; Ruf and Lançon 2004).

Hasil kakao (Theobroma cacao) dipengaruhi oleh kondisi lingkungan selama pembungaan, polinasi, pembentukan buah, dan pengembangan buah serta proses maturasi (Schwendenmann dkk. 2010). Monokultur tanpa naungan jauh lebih sensitif dibandingkan kakao yang berkembang di bawah wanatani naungan. Curah hutan yang rendah dan kekeringan menyebabkan gugurnya daun dan memengaruhi perkembangan serta pematangan, dan menyebabkan rendahnya jumlah cangkang kakao. Petani di Sulawesi melaporkan penurunan hasil sampai 38\% setelah kekeringan terkait ENSO yang parah pada tahun 1997 dan 2002 (Keil dkk. 2008); kekeringan dapat menyebabkan penurunan hasil sampai 50\% (Zuidema dkk. 2005). Di sisi lain, peningkatan curah hujan dapat mendorong semakin besarnya kerugian hasil karena penyakit busuk hitam (Phytophthora palmivora) (Schwendenmann dkk. 2010).

Tanaman kopi cukup sensitif dengan perubahan iklim mikro. Sebagai contoh, kisaran suhu optimal untuk kopi Arabica aalah $18-21^{\circ} \mathrm{C}$, dengan fotosintesis bersih menurun tajam melampaui batas ini, hingga mendekati 0 pada $34^{\circ} \mathrm{C}$ (Lin 2007). Di atas $23^{\circ} \mathrm{C}$, perkembangan dan pematangan buah dipercepat, menyebabkan penurunan kualitas, dan di bawah $18^{\circ} \mathrm{C}$, pertumbuhan tertekan. Mempertahankan pohon naungan untuk kopi adalah strategi yang mudah dan sesuai untuk membatasi kerugian panen selama fluktuasi iklim mikro. Pertumbuhan dan perkembangannya juga terkait dengan siklus air musiman. Bunga bergantung pada perpanjangan musim kering untuk pembentukan tunas, sedangkan ketersediaan air di musim hujan menentukan ukuran buah (Lin 2010). Waktu atau jumlah curah hujan pada saat-saat kritis perkembangan kopi dapat memiliki pengaruh yang signifikan pada hasil.

Untuk jagung, suhu optimal rerata untuk tanaman jagung pada iklim sedang, dataran tinggi tropis dan dataran rendah tropis terletak pada kisaran masingmasing $20-30^{\circ} \mathrm{C}, 17-20^{\circ} \mathrm{C}$ dan $30-34^{\circ} \mathrm{C}$ (Cairns dkk. 2012). Setiap suhu harian maksimum di atas $34^{\circ} \mathrm{C}$ dapat menyebabkan kerugian yang cukup besar di Malinau, sementara derajat akumulasi suhu maksimum harian di atas $32^{\circ} \mathrm{C}$ selama periode pengisian butir-butirnya telah terbukti berkorelasi negatif dengan hasil.
Sebuah analisis baru-baru ini dari uji coba historis jagung yang dikombinasikan dengan data cuaca menunjukkan bahwa untuk setiap derajat di atas $30^{\circ} \mathrm{C}$, hasil butiran turun sampai $1 \%$ pada kondisi optimal tadah hujan dan sampai 1,7\% pada kondisi kekeringan (Lobell dkk. 2011). Walaupun kekeringan memengaruhi semua tahap pertumbuhan dan produksi, tahap reproduksi adalah yang paling sensitif. Kekeringan selama periode ini menyebabkan pengurangan hasil yang signifikan, terkait dengan penurunan ukuran biji (kernel) (Cairns dkk. 2012). Jagung juga sensitif terhadap genangan air yang memengaruhi 18\% produksi di Asia Selatan dan Tenggara, yang juga menyebabkan turunnya produksi tahunan sebesar $25-30 \%$.

Apabila tanah tidak dapat mengalirkan air setelah curah hujan yang intens, penurunan konsentrasi oksigen secara perlahan-lahan pada ruang perakaran menyebabkan akar tanaman menderita hypoxia (oksigen rendah) dan, selama terjadinya genangan air berkepanjangan (lebih dari 3 hari), mengalami anoxia (tanpa oksigen) (Zaidi dan Singh 2001; Zaidi dkk. 2003). Efek sekunder dari genangan air adalah kekurangan hara makro yang penting dan suatu akumulasi hara beracun akibat penurunan serapan tanaman akar dan perubahan potensial redoks (Cairns dkk. 2012). Tanaman menjadi lebih rentan terhadap genangan air selama tahap awal pembibitan sampai pembungaan.

\subsubsection{Hutan}

Hutan dan pohon tidak terlalu sensitif terhadap variabilitas iklim dan kejadian iklim dibandingkan tanaman pertanian. Akumulasi $\mathrm{CO}_{2}$ bahkan lebih menguntungkan bagi produktivitasnya, namun pada jangka waktu yang lebih panjang, perubahan iklim dapat memengaruhi struktur dan komposisi hutan. Namun demikian, penelitian tentang sensitivitas hutan dan kerentanan terhadap perubahan iklim di Indonesia masih sangat dini dan banyak kesenjangan pengetahuan yang perlu untuk dipahami.

Beberapa studi dari Indonesia dan Amazon telah menunjukkan sensitivitas hutan tropis terhadap peristiwa kekeringan yang terkait dengan El Niño. ENSO meningkatkan risiko, intensitas dan penyebaran kebakaran hutan karena naiknya suhu dan menurunnya curah hujan, khususnya pada hutan yang terjamah.

Pada kondisi curah hujan dan kelembaban normal, sebagian besar kebakaran (baik yang terjadi secara 
alami maupun antropogenik) akan padam dengan datangnya musim hujan. Iklim mikro yang lembab pada hutan tropis yang tidak terjamah biasanya tidak memunculkan kebakaran (Roberts 2000). Namun, fragmentasi hutan dan perubahan tata guna lahan telah menyebabkan terputusnya lapisan tajuk, memungkinkan cahaya matahari untuk masuk dan mengeringkan serasah daun hutan, menurunkan retensi kelembaban secara keseluruhan. Akibatnya adalah peningkatan bahan bakar yang sangat mudah terbakar (Roberts 2000). Hutan yang tersisa mengalami kerusakan berat karena pembalakan dan memiliki tepian yang kering, rawan kebakaran yang kemudian meningkatkan kekeringan hutan dan penumpukan bahan bakar (Cochrane dan Laurance 2002).

Sensitivitas hutan terhadap peningkatan kebakaran dengan kebakaran yang berulang, menyebabkan umpan balik yang positif. Kebakaran hutan di Amazon, sebagai contoh, biasanya memiliki intensitas garis kebakaran hutan menengah yaitu kurang dari $50 \mathrm{~kW} / \mathrm{m}^{2}$. Namun setelah kebakaran, bahan bakar yang sangat mudah terbakar terbentuk dari tegakan pohon yang mati, kolonisasi jenis-jenis rumput dan serasah, secara langsung memperbesar tingkat keparahan setiap kebakaran sekunder (Cochrane dan Schulze 1998). Hal ini juga terjadi di hutan tropis dataran rendah Sumatera, yang kebakaran El Niño menyebabkan kematian masal, tumbangnya pohon dan dominasi spesies pionir kayu lunak, yang telah sangat meningkatkan risiko kebakaran (Kinnaird dan O'Brien 1998). Laju rerata dan intensitas kebakaran hutan serta deforestasi akan meningkat karena hutan yang sebelumnya terbakar telah bertambah (Cochrane dkk. 1999). Hutan terbakar juga menjadi peka terhadap hujan lebat, yang menyebabkan erosi tanah dan pencucian hara karena intersepsi curah hujan yang buruk yang disebabkan oleh kerusakan tajuk.

Kekeringan juga menyebabkan kematian pohon, khususnya apabila dalam jangka panjang. Angka kematian pohon pada hutan yang didominasi dipterokarpa di Kalimantan Timur ternyata tinggi setelah kekeringan pada kejadian El Niño 1997/1998. Sementara kebakaran mematikan pohonpohon dengan ukuran batang yang lebih kecil, kekeringan menyebabkan kematian pada pohon dengan ukuran batang yang lebih besar. Pohonpohon mati karena kehabisan simpanan energi akibat penurunan fotosintesis atau ketidakmampuan untuk pulih setelah kegagalan hidraulik (van Nieuwstadt dan Sheil 2005).

Di hutan lindung Sungai Wain di Kalimantan, kematian meningkat sampai 20\%-26\% pada pohonpohon dengan diameter setinggi dada (dbh) lebih besar dari $10 \mathrm{~cm}$ selama dua tahun setelah kekeringan, dan kematian pada pohon yang spesifik berdasarkan jenis dengan dbh lebih besar dari $30 \mathrm{~cm}$ bervariasi sepuluh kali lipat, sehingga mengubah komposisi spesies (van Nieuwstadt dan Sheil 2005). Namun demikian, kematian pohon karena kebakaran tidak dapat dengan mudah dibedakan dengan kematian akibat kekeringan, karena kebakaran hanya terjadi selama kejadian kekeringan sedangkan kematian karena kekeringan terus berlangsung.

\subsubsection{Kesehatan dan permukiman}

\section{Kesehatan}

Banyak bakteri dan vektor menular penyebab penyakit di Indonesia yang sensitif terhadap iklim dan perubahan suhu serta curah hujan sangat mungkin meningkatkan penyebarannya. Penyakit diare dikaitkan dengan kemiskinan dan kebersihan, tetapi diperparah oleh pengaruh suhu tinggi terhadap proliferasi bakteri (Checkley dkk. 2000). Beberapa penelitian menunjukkan hubungan antara El Niño dan peningkatan prevalensi diare di masyarakat, terutama di kalangan anak-anak (Checkley dkk. 2000; Bennett dkk. 2012.). Curah hujan yang lebih tinggi dan banjir yang lebih sering juga akan menyebabkan penyakit-penyakit pencernaan yang lebih sering dan penyakit menular yang terbawa air seperti dermatosis karena penurunan kualitas air permukaan dan peningkatan polusi (Cruz dkk. 2007).

Curah hujan yang lebih tinggi disertai suhu yang lebih panas dan sanitasi yang buruk diproyeksikan akan memperluas vektor malaria dan demam berdarah di seluruh Asia Tenggara (Cruz dkk. 2007). Diperkirakan pada 2085, sekitar 6 miliar orang secara global cenderung berisiko tertular demam berdarah sebagai akibat perubahan iklim, yaitu 2,5 miliar lebih besar dibandingkan jika iklim tidak berubah (Hales dkk. 2002). Di Indonesia, korelasi positif telah ditemukan antara curah hujan bulanan yang meningkat dan jumlah kasus demam berdarah dengue (ADB 2011). Demam berdarah dengue saat ini bukan merupakan ancaman kesehatan di Malinau tapi bisa terjadi jika tidak ada tindakan pencegahan. 


\section{Permukiman}

Banjir di daratan telah memindahkan lebih dari 80.000 orang di Kalimantan Timur sejak 2007 (DNPI dan GoEK 2010). Namun demikian, hubungan antara banjir dan curah hujan adalah kompleks, dan dipengaruhi oleh frekuensi dan intensitas curah hujan, demikian juga pada area dengan karakteristik hidrologis dan sungai yang spesifik (dan tidak hanya terkait jumlah curah hujan rerata). Sensitivitas area terhadap curah hujan yang intens atau terkait risiko dampak bencana dari banjir, juga terkait dengan berbagai faktor lain yang berpengaruh seperti degradasi daerah aliran sungai, penyumbatan saluran drainase, penggundulan hutan dan status bangunan dan infrastruktur.

Mengingat ketidakpastian seputar curah hujan tahunan rerata di masa depan, sebuah laporan Panel AntarPemerintah untuk Perubahan Iklim (IPCC) tentang kejadian ekstrem memperingatkan terjadinya curah hujan besar yang lebih sering (misalnya, yang melebihi $300 \mathrm{~mm}$ pada satu hari) di Asia Tenggara (Field dkk. 2012). Selain itu, Peta Jalan Sektoral Perubahan Iklim Indonesia telah mengidentifikasi wilayah di sepanjang sungai-sungai utama di Kalimantan Timur yang memiliki risiko banjir di masa depan yang sangat tinggi (Hadi 2010). Banjir lokal yang parah adalah bencana yang biasa di Malinau, yang air banjirnya dapat naik 2-4 $\mathrm{m}$ di atas tingkat normal (Liswanti dkk. 2011).

\subsubsection{Ringkasan dan kesimpulan}

Produksi pertanian dan hutan sensitif terhadap variabilitas iklim, ke-ekstremannya dan perubahan iklim jangka panjang. Padi sangat sensitif terhadap suhu tinggi, khususnya pada tahap perkembangan yang kritis, dan terhadap peningkatan dan penurunan curah hujan. Pisang membutuhkan curah hujan yang melimpah dengan penurunan produksi pada suhu di atas $27^{\circ} \mathrm{C}$, sedangkan singkong tumbuh subur dalam kondisi kekeringan dan pada $32^{\circ} \mathrm{C}$. Ubi jalar tahan terhadap kekeringan, tetapi tidak tahan dengan genangan air, sedangkan kakao dan kopi sensitif terhadap tekanan panas dan air. Hutan tropis rentan terhadap kematian akibat kemarau dan kebakaran selama terjadinya El Niño.

Tingkat sensitivitas dipengaruhi oleh tekanantekanan lain dan umpan baliknya. Hutan, sebagai contoh, lebih sensitif terhadap kejadian kekeringan dan kebakaran apabila telah terdegradasi atau ditebang (Roberts 2000). Tanaman pangan monokultur dan pada tanah yang terdegradasi lebih sensitif terhadap kenaikan suhu, curah hujan, kekeringan dan wabah hama dibandingkan tanaman yang tumbuh dalam sistem lebih kompleks atau wanatani (Verchot dkk. 2007; Garrity dkk. 2010; Pramova dkk. 2012). Sanitasi yang buruk, polusi, dan degradasi DAS meningkatkan keparahan banjir dan perkembangbiakan bakteri dan vektor berat saat curah hujan tinggi (Cruz dkk. 2007). Pengelolaan lingkungan hidup yang lebih baik dan berkelanjutan dapat menurunkan sensitivitas dan akhirnya berdampak di hampir semua sektor dan sistem.

\subsection{Kapasitas Adaptif}

Seperti disebutkan di atas, sumber daya yang mendukung kapasitas adaptif termasuk infrastruktur irigasi dan stasiun cuaca (fisik); kelompok simpanan masyarakat dan kelompok petani (sosial); sumber-sumber air bersih yang dapat diandalkan dan lahan produktif (alami); asuransi mikro dan sumber-sumber pemasukan yang beragam (keuangan); dan pengetahuan, keterampilan dan pendidikan (manusia).

Di daerah perdesaan di Malinau, masyarakat tidak memiliki akses yang pasti ke sumber daya alam yang tersedia; tidak hanya karena konflikkonfik sosial dan ketidakjelasan tenurial lahan, tapi juga karena meningkatnya keberadaan konsesi pembalakan, pertambangan dan kelapa sawit. Walaupun penduduk di wilayah ini bergantung pada sumber daya hutan ketika sumber daya yang normal terganggu, terdapat beberapa contoh strategi pengelolaan sumber daya secara proaktif untuk melakukan adaptasi dari waktu ke waktu, dengan pengecualian Tane' Olen di Setulang.

Diversifikasi aktivitas penghidupan di dalam maupun di luar pertanian juga rendah, khususnya di wilayah perdesaan di hulu yang didominasi oleh perladangan berpindah dan pengumpulan hasilhasil hutan. Sebagian besar rumah tangga tidak bisa mengandalkan pendapatan di luar pertanian yang membuat mereka sangat rentan jika gagal panen. Desa-desa Setulang merupakan pengecualian karena penduduknya memperoleh pendapatan dari kiriman anggota muda keluarga mereka yang bekerja di perkebunan di Malaysia dan negara lain. Migrasi ini memiliki konsekuensi positif, seperti adanya uang tunai bagi rumah tangga untuk membeli peralatan; dan konsekuensi negatif, seperti berkurangnya modal dan pengetahuan sosial, seperti didiskusikan oleh anggota masyarakat selama lokakarya. Di wilayah 
kabupaten, pekerjaan yang menghasilkan gaji kebanyakan hanya tersedia bagi penduduk di hilir yang dekat dengan Kota Malinau, atau di beberapa desa yang dapat mencari pekerjaan di beberapa kantor administrasi kecamatan (Moeliono dan Limberg 2009). Di sepanjang jangkauan sungai yang masyarakatnya hampir sepenuhnya bergantung pada pertanian, memperoleh uang tunai bisa menjadi masalah. Perladangan berpindah menyediakan bahan pangan pokok namun tidak menghasilkan uang tunai, sementara budidaya kopi dan kakao secara rendah teknologi menjadi terlalu ekstensif untuk dapat menyediakan pemasukan tetap (Levang dkk. 2002).

Kemiskinan di Malinau tidak terkait dengan pendapatan namun dengan kurangnya akses ke pendidikan dan fasilitas kesehatan. Misalnya, di bagian hulu Malinau dan Sungai Tubu, tidak terdapat sekolah dan kondisi sanitasinya memprihatinkan (Levang dkk. 2002). Aksesibilitas adalah isu lain, mengingat banyak desa yang berada di tengah dan di hulu yang tidak terhubung dengan jaringan jalan yang memadai. Kondisi ini menghambat komunikasi dengan dan akses oleh pemerintah dan penyuluh, juga upaya untuk meminimumkan risiko bencana selama kejadian cuaca ekstrem. Namun demikian, berkat kedekatan mereka pada hutan, desa-desa ini memiliki suplai daging hewan liar (misalnya, babi hutan, beberapa jenis rusa, monyet dan burung) serta beberapa hasil lain dengan nilai lokal yang besar.

Kebanyakan desa hampir tidak memiliki infrastruktur pertanian, seperti fasilitas penyimpanan gabah atau sistem irigasi. Kabupaten juga tidak memiliki stasiun cuaca untuk memberikan informasi kepada petani. Dinas petanian kabupaten menekankan bahwa karena ketiadaan prakiraan hujan yang dapat digunakan untuk memberikan informasi secara tepat waktu kepada petani, maka hanya data tingkat provinsi yang tersedia.

Desa Setulang diuntungkan karena kedekatannya dengan hutan dan Kota Malinau, walaupun akses ke kota hanya dimungkinkan belum lama ini dengan konstruksi jalan tanah yang baru. Aset dan sumber daya yang ikut andil dalam meningkatkan kapasitas adaptif masyarakat desa termasuk modal sosial yang kuat, kesatuan dan kebersamaan, sumber daya hutan yang relatif tidak terganggu, keahlian dan pengetahuan dalam pengelolaan hutan, dan lembaga desa yang kuat (lihat Bab 2.2 dan 4.1). Kesenjangan kapasitas adaptif di desa terutama terkait dengan kurangnya infrastruktur pertanian, seperti sistem irigasi dan infrastruktur informasi, seperti jaringan telekomunikasi.

Masalah utama lain terkait kapasitas adaptif adalah ketidakpastian hukum mengenai hak berdasarkan Tane' Olen dan khususnya, konflik dengan desa tetangga yang berbatasan. Seperti dibahas pada Bab 4.1, penduduk Setulang enggan mengembangkan sawah berdekatan dengan batas desa, sehingga mengurangi ketersediaan jumlah lahan untuk diversifikasi, khususnya untuk rumah tangga baru, maupun kelebihan hasil panen.

Kebutuhan uang tunai yang terus meningkat diperoleh dari penjualan kelebihan beras dan sayur dan kadang-kadang dari ekoturisme. Namun demikian, karena perubahan iklim dan kekurangan lahan akibat pertumbuhan penduduk, mereka mungkin akan kesulitan untuk memastikan kelebihan beras yang dimiliki apakah dijual untuk mendapatkan uang tunai atau untuk ketahanan pangan. Kaum muda yang membutuhkan uang tunai dan peluang untuk mengembangkan diri, bisa jadi akan mulai mengeksploitasi hutan secara intensif untuk memperoleh penghasilan atau bahkan meninggalkan desanya. Penduduk Desa Setulang khawatir tren ini akan menyebabkan hilangnya pengetahuan lokal dan pengelolaan Tane' Olen yang buruk, sebuah kekhawatiran yang telah muncul pada studi sebelumnya yang dilakukan di desa ini (Iwan 2006; Iwan dan Limberg 2009).

Rencana tata guna lahan Setulang tidak diintegrasikan ke dalam rencana dan prioritas dinas-dinas kabupaten yang penting (kecuali dinas kehutanan yang terlibat dalam pengajuan izin Hutan Desa). Sebagai akibatnya, rencana kabupaten dan provinsi untuk mengembangkan pertambangan batu bara dan kelapa sawit di desa ini kemungkinan bertentangan dengan sasaran yang diinginkan penduduk. Lebih jauh lagi, hal ini dapat mengancam kapasitas adaptif mereka yang sangat bergantung pada pemahaman para pakar mereka tentang hutan dan sumber dayanya (hal yang pernah ditekankan oleh Sheil dkk. (2009) untuk daerah perdesaan lain di Malinau).

\subsection{Kebijakan Adaptasi}

Pemerintah Indonesia telah mengambil beberapa langkah yang dirancang untuk mengarusutamakan 
perubahan iklim ke dalam prioritas pembangunan nasional lainnya. Pertama adalah Rencana Aksi Nasional untuk Perubahan Iklim pada tahun 2007, yang menetapkan sejumlah aksi yang bertujuan untuk mengurangi emisi gas rumah kaca dan mendorong adaptasi.

Dokumen ke dua yang kemudian disusun, berjudul: Perencanaan Pembangunan Nasional: Respon Indonesia terhadap perubahan iklim (National Development Planning: Indonesia's Responses to Climate Change, yang juga dikenal sebagai buku kuning. Buku ini berfungsi sebagai panduan multisektoral bagi pemerintah untuk mengintegrasikan perubahan iklim ke dalam Rencana Pembangunan Nasional negara secara keseluruhan melalui intervensi jangka panjang dan menengah. Dokumen ini meletakkan landasan kerja untuk Dana Perwalian Perubahan Iklim Indonesia (Indonesia Climate Change Trust Fund) dan strategi rencana terpadu dengan prinsipprinsip, pro rakyat miskin, pro lapangan pekerjaan, pro pertumbuhan dan pro lingkungan hidup.

Bappenas kemudian meluncurkan Peta Jalan Sektoral Perubahan Iklim untuk mengadaptasikan Rencana Aksi Nasional Perubahan Iklim pada Rencana Pembangunan Nasional Jangka Menengah 5 tahun 2010-2014, dan untuk menyediakan masukan untuk Rencana Pembangunan Nasional Jangka Menengah yang berikutnya sampai 2030. Peta Jalan ini pada dasarnya merupakan panduan kebijakan untuk mengarusutamakan dan mengimplementasikan adaptasi nasional dan kegiatan-kegiatan mitigasi (terkait peraturan, program dan proyek, skema pendanaan dan kapasitas pengembangan) ke dalam Rencana Pembangunan Nasional Jangka Menengah untuk 2010-2030.

Peta Jalan mengidentifikasi tiga sektor dengan pengaruh utama pada upaya-upaya mitigasi dan adaptasi di sektor kehutanan, yaitu: pertanian, energi dan pertambangan. Peta ini juga mengidentifikasi beberapa sektor lain yang secara tidak langsung dapat memengaruhi hutan dan masyarakat yang bergantung pada hutan, yaitu: laut dan perikanan, transportasi, industri dan kesehatan. Peta Jalan juga melakukan upaya awal untuk mengkaji kerentanan sektor kehutanan Indonesia di tingkat nasional, namun menyimpulkan bahwa dibutuhkan data yang lebih lengkap untuk perencanaan adaptasi yang efektif, seperti data iklim yang berskala lebih kecil dan peta kerentanan titik api yang penting.
Beberapa contoh strategi adaptasi diberikan untuk tiga aspek fokus (1) sumber daya hutan, (2) masyarakat yang bergantung pada hutan dan (3) industri hutan. Langkah-langkah terkait sumber daya hutan termasuk penyesuaian dan perluasan taman nasional serta suaka margasatwa, revitalisasi sungai dan perluasan wilayah konservasi maritim. Pengembangan kapasitas dan kelembagaan serta penguatan jaringan kerja direkomendasikan bagi masyarakat yang bergantung pada hutan sehingga mereka dapat membentuk kelompok-kelompok, menyelesaikan sengketa, menjernihkan peran dan tanggung jawab, memperoleh hak pengelolaan hutan dan melanjutkan pembuatan keputusan atas sumber daya secara kolektif. Pengelolaan hutan adaptif direkomendasikan pada semua bidang fokus, dengan penekanan khusus pada pemantauan hutan.

Dewan Nasional Perubahan Iklim (DNPI) dibentuk sebagai pusat nasional untuk merancang kebijakan, strategi dan program perubahan iklim, dan untuk mengkoordinasikan instansi-instansi sektoral ketika merencanakan intervensi adaptasi. DNPI, yang dikepalai oleh Presiden, beranggotakan semua kementerian dan beroperasi melalui beberapa kelompok kerja yang memiliki karyawan tetap. Namun demikian, DNPI bukan merupakan badan eksekutif dan tidak memiliki status hukum apapun.

Dana Perwalian Perubahan Iklim Indonesia, dibentuk bersama pada 2009 oleh Kementerian Perencanaan Pembangunan Nasional dan Kementerian Keuangan, berfungsi untuk menarik, mengelola dan memobilisasi investasi keuangan dalam mitigasi dan adaptasi perubahan iklim. Lembaga ini berperan sebagai sebuah portal keuangan untuk menerima dan menyalurkan sumber daya dari dana internasional, pemerintah lain, mitra pembangunan, dan mekanisme pendanaan perubahan iklim yang lain seperti dana adaptasi (Adaptation Fund). Lembaga ini juga menggabungkan dana-dana tersebut dengan pendanaan dari sektor nasional dan swasta sekiranya sesuai.

Sebuah Rencana Aksi Nasional Adaptasi Perubahan Iklim yang baru diluncurkan pada akhir tahun 2012 oleh Bappenas dan DNPI, menetapkan intervensi adaptasi pada sektor pembangunan yang utama. Kebijakan ini pada dasarnya merupakan pemutakhiran peta jalan sektoral dengan fokus yang lebih besar pada adaptasi. 
Pada tingkat lokal di Malinau, Gerdema dapat memberikan kontribusi penting bagi kapasitas adaptif di kabupaten. Gerakan ini dibentuk pada awal 2000 dan pada fase keduanya disempurnakan melalui peluncuran Pemberdayaan Masyarakat untuk Pembangunan Perdesaan, untuk mendukung proses perencanaan dari bawah ke atas di tingkat masyarakat. Namun demikian, proses ini tidak berjalan sebagaimana dimaksudkan dan diharapkan bahwa, dengan implementasi Gerdema dan pengerahan staf teknis (Satgas, lihat Bab 4.2.4), prioritas masyarakat akan direfleksikan dengan lebih baik. 


\section{Intervensi Adaptasi Berbasis Masyarakat}

\subsection{Prioritas Masyarakat untuk Masa Depan}

Aspirasi masyarakat yang muncul selama latihan melihat masa depan dikelompokkan ke dalam klaster-klaster strategi. Anggota masyarakat Setulang kemudian mengurutkannya sesuai prioritas intervensi yang dapat mulai mereka implementasikan dengan memanfaatkan aset dan sumber daya desa yang ada. Tiga klaster strategi didiskusikan: (1) pembangunan pertanian (agricultural development/AD); (2) pengelolaan wilayah desa (village area management VAM); dan (3) pengelolaan Tane' Olen dan diversifikasi mata pencaharian (management of Tane' Olen and livelihood diversification/TOM) (Tabel 6).
Strategi pembangunan pertanian memiliki sasaran ganda. Salah satu sasaran yang penting adalah untuk mengembangkan arena baru dengan prospek yang menguntungkan untuk ditawarkan bagi kaum muda sebagai alternatif yang menarik daripada bermigrasi ke kota. Menanam lebih banyak jenis tanaman di luar padi dan singkong, dimaksudkan untuk memperkuat penghidupan dan ketahanan pangan di bawah ancaman kekeringan dan banjir. Pengembangan produksi karet, buah-buahan, kopi dan kakao melalui sistem wanatani diharapkan untuk meningkatkan ketahanan dan kelestarian secara keseluruhan karena kondisi perubahan iklim.

Tabel 6. Strategi prioritas berbasiskan aset masyarakat

\begin{tabular}{|c|c|c|}
\hline & Intervensi & Kegiatan lanjutan \\
\hline \multirow[t]{5}{*}{ AD.1 } & \multirow[t]{5}{*}{$\begin{array}{l}\text { Pengembangan sawah } \\
\text { beririgasi. }\end{array}$} & $\begin{array}{l}\text { Mendapatkan bantuan untuk negosiasi sewa lahan sawah dari pemilik lahan/ } \\
\text { desa-desa lain. }\end{array}$ \\
\hline & & $\begin{array}{l}\text { Mendapatkan bantuan untuk peralatan (misalnya, traktor, mesin perontok, } \\
\text { bajak). }\end{array}$ \\
\hline & & Meminta jasa penyuluhan tentang teknik-teknik irigasi. \\
\hline & & Membangun jaringan irigasi dari sungai dengan tabung/pipa irigasi. \\
\hline & & Membangun jalan ke sawah. \\
\hline \multirow[t]{2}{*}{ AD. 2} & \multirow[t]{2}{*}{$\begin{array}{l}\text { Pengembangan } \\
\text { wanatani karet. }\end{array}$} & $\begin{array}{l}\text { Menerapkan pengetahuan wanatani (misalnya, tanaman apa yang tahan } \\
\text { kekeringan dan banjir) dan meminta jasa penyuluhan dari dinas perkebunan jika } \\
\text { dibutuhkan. }\end{array}$ \\
\hline & & $\begin{array}{l}\text { Mengembangkan lokasi percontohan dan mengukur kelayakan berbagai pilihan } \\
\text { yang berbeda. }\end{array}$ \\
\hline \multirow[t]{2}{*}{ AD.3 } & \multirow{2}{*}{$\begin{array}{l}\text { Pengembangan kebun } \\
\text { buah-buahan, kopi dan } \\
\text { kakao. }\end{array}$} & Meminta jasa penyuluhan tentang penanganan hama dan penyakit. \\
\hline & & $\begin{array}{l}\text { Menerapkan pengelolaan yang lebih intensif (misalnya, dengan pupuk) untuk } \\
\text { meningkatkan hasil panen buah. }\end{array}$ \\
\hline
\end{tabular}

VAM.1 Pembangunan rumah adat yang baru.
Mengombinasikan dengan wilayah hidup untuk menciptakan ruang yang terpadu.

Merencanakan desain.

Mengumpulkan bahan: kayu ulin, kapur dan meranti.

Mendapatkan bantuan (misalnya, dari Gerdema) untuk membeli atau menyewa traktor dan alat-alat lain yang dibutuhkan.

Membangun, mengukir dan mengecat.

VAM.2 Pembangunan jaringan Mendapatkan bantuan (misalnya, dari Gerdema) untuk membeli atau menyewa jalan yang menuju Tane' traktor dan alat-alat lain yang dibutuhkan. 
Lanjutan Tabel 6. Strategi...

\begin{tabular}{|c|c|c|}
\hline & Intervensi & Kegiatan lanjutan \\
\hline \multirow[t]{3}{*}{ TOM.1 } & \multirow{3}{*}{$\begin{array}{l}\text { Pengembangan } \\
\text { kegiatan pariwisata. }\end{array}$} & Membangun sebuah pusat pariwisata. \\
\hline & & Menempatkan label identifikasi pohon dan informasi lain. \\
\hline & & Mengembangkan wisata berburu berdasarkan adat berburu tradisional. \\
\hline \multirow[t]{3}{*}{ TOM.2 } & \multirow[t]{3}{*}{$\begin{array}{l}\text { Pengembangan usaha } \\
\text { kecil kerajinan tangan. }\end{array}$} & $\begin{array}{l}\text { Membuat kerajinan tangan untuk dijual kepada para turis dan pembeli di } \\
\text { luar desa. }\end{array}$ \\
\hline & & Meningkatkan desain kerajinan tangan. \\
\hline & & Menciptakan pasar desa. \\
\hline \multirow[t]{3}{*}{ TOM.3 } & \multirow{3}{*}{$\begin{array}{l}\text { Perbaikan pengelolaan } \\
\text { sumber daya hutan, } \\
\text { khususnya HHBK. }\end{array}$} & $\begin{array}{l}\text { Memperbaiki fasilitas-fasilitas pengelolaan (misalnya, fasilitas pengelolaan } \\
\text { kelompok Tane' Olen). }\end{array}$ \\
\hline & & $\begin{array}{l}\text { Membentuk kelompok kerja untuk mengelola HHBK (misalnya, rotan, bambu, } \\
\text { daun sang) }\end{array}$ \\
\hline & & $\begin{array}{l}\text { Melaksanakan inventarisasi sumber daya hutan komprehensif, yang mencakup } \\
\text { berbagai HHBK penting, untuk mendukung pengelolaan berkelanjutan. }\end{array}$ \\
\hline
\end{tabular}

Karet mendapatkan penekanan khusus karena beberapa penduduk Desa Setulang telah mengamati hasil ekonomi yang menguntungkan di desa lain dari menjual lateks. Masyarakat mengatakan bahwa mereka akan mudah menjual karet, karena sebelumnya telah ada pembeli yang datang. Kegiatan ini juga dianggap menguntungkan yang akan menarik bagi kaum muda.

Strategi yang dirancang untuk meningkatkan pengelolaan desa juga memiliki sasaran dan manfaat ganda yang diharapkan. Pembentukan ruang adat yang baru di rumah panjang di atas lahan yang lebih tinggi akan bermanfaat ketika terjadi banjir, menyediakan tempat berlindung bagi masyarakat yang rumahnya terendam air. Pada saat yang lain, rumah adat berfungsi sebagai pusat untuk kegiatankegiatan budaya dan sebagai fasilitas akomodasi bagi pengunjung. Selain itu, melekatkan ruang hidup pada bangunan adat akan mengembalikan tradisi Dayak yaitu Lamin Adat, yang menggunakan rumah panjang, tempat 20-30 keluarga dapat tinggal bersama dengan tetap memungkinkan interaksi maupun privasi. Semua bahan bangunan tersedia secara lokal dan tukang kayu berpengelaman di Setulang dapat mengukir dan melukisnya dengan desain-desain Dayak.

Klaster strategi terakhir yang dibahas adalah pengelolaan Tane' Olen, yang mencakup programprogram pariwisata, pengelolaan sumber daya dan mata pencaharian alternatif. Masyarakat berharap untuk meningkatkan hasil ekonomi dari mengelola Tane' Olen secara berkelanjutan, sembari melindungi keanekaragaman hayati dan praktik-praktik adat.
Membangun ekoturisme dipandang sebagai sebuah langkah penting dalam mencapai tujuan ini. Untuk itu, fasilitas pariwisata perlu dibangun atau ditingkatkan dan kemampuan berbahasa Inggris penduduk desa harus ditingkatkan. Wisata berburu merupakan pilihan lain, berdasarkan praktik-praktik tradisional Dayak untuk perburuan babi hutan dan daging satwa liar lainnya. Materi informasi dapat dibuat bersamaan dengan inventarisasi sumber daya menyeluruh yang sedang berlangsung dengan bantuan GIZ. Inventarisasi ini dirancang untuk mendukung pengelolaan HHBK yang lebih baik dan lebih berkelanjutan; suatu kelompok kerja dapat ditetapkan untuk masing-masing HHBK.

Salah satu HHBK yang penting adalah rotan, yang digunakan masyarakat Setulang untuk membuat kerajinan tangan tradisional dan barang-barang rumah tangga, seperti tikar dan keranjang. Kerajinan tangan itu sendiri merupakan daya tarik bagi para turis karena Dayak Kenyah memiliki pola-pola yang khas dan indah. Sebuah pasar kerajinan tangan dapat dibangun untuk menciptakan sumber pemasukan alternatif dan untuk menginformasikan pengunjung tentang budaya Dayak. Saat ini, kerajinan tangan rotan hanya dibuat untuk penggunaan rumah tangga saja.

\subsection{Intervensi-intervensi Terpilih}

Berdasarkan prioritas masyarakat, dua intervensi adaptasi dipilih untuk perencanaan dan analisis lebih jauh: (1) wanatani karet dan (2) pembuatan dan penjualan kerajinan tangan rotan. 


\subsubsection{Wanatani karet}

Setiap rumah tangga yang berminat untuk melakukan wanatani karet dapat mengalokasikan 1 ha tanpa mengorbankan produksi beras mereka. Sistem wanatani karet dengan pohon buah yang terkait (RAS-2), sebagaimana dikembangkan dan diuji oleh World Agroforestry Centre(ICRAF), dapat digunakan sebagai model (Wulan dkk. 2008).

Dalam sistem RAS-2, pohon karet ditanam dengan kerapatan normal (550 batang/ha) bersama dengan pohon berkayu tetap dan buah-buahan (92-270 pohon/ha) setelah pembersihan lahan. Hasil panen tahunan, terutama sawah di dataran tinggi, dapat ditumpangsarikan untuk 2-3 tahun pertama dengan bantuan pupuk. Beberapa jenis pohon seperti rambutan (Nephelium lappaceum), durian (Durio zibethinus), petai (Parkia speciosa) dan tengkawang (Shorea spp.) dapat ditanam, demikian menurut uji lapangan ICRAF. Semua jenis pohon buah ini telah tumbuh di wilayah desa atau di Tane' Olen. Dengan RAS-2, regenerasi alami dijumpai di antara lajur-lajur karet dan petani memutuskan jenis yang beregenerasi alami yang mana yang akan dipertahankan.

Selain lahan dan tenaga kerja, modal utama adalah bibit karet dan pohon buah, pupuk dan asam semut/asam format untuk lateks. Rerata hasil lateks yang dapat dipasarkan (100\% kadar karet kering/DRC) per tahun dengan sistem RAS-2 adalah $1.131 \mathrm{~kg} / \mathrm{ha}$. Menurut data terakhir yang dipublikasikan (Peramune dan Afs 2007), harga di petani per kg/DRC berkisar antara Rp 3.000-4.000. Panen biasanya dimulai pada umur 8 tahun atau sebelumnya.
Bibit karet dijual dalam bentuk tunggul yang bertunas atau dalam kantung polibag. Di Kalimantan Selatan, tanaman klonal dalam polibag tersedia di pembibitan berlisensi dengan harga satuannya sekitar Rp 3.500 dan pada pembibitan yang tidak berlisensi harga satuannya adalah Rp 1.500-2.000. Di Kalimantan Tengah dan Timur, bibit yang baik tersedia dengan harga Rp 4.000-6.000 per tanaman bergantung pada jarak (Peramune dan Afs 2007). Untuk membudidayakan sekitar 550 batang/ ha, diperlukan penanaman sebanyak 650 tunas atau polibag.

Hasil rerata pohon buah (rendah dan tinggi) disajikan pada Tabel 7. Hasil panen bervariasi sesuai praktik-praktik pengelolaan dan parameter lingkungan hidup (misalnya, iklim dan tanah).

Apabila padi gogorancah ditanam dan dipanen pada 1-2 tahun pertama, hasil total hingga $1.000 \mathrm{~kg}$ per hektar bisa didapatkan (Budidarsono dkk. 2010).

Kebutuhan tenaga kerja selama fase pembentukan RAS-2 adalah 125 orang-hari dalam tahun pertama dan 100 orang-hari dalam tahun kedua. Selama fase operasional, rerata 85 orang-hari dibutuhkan setiap tahunnya, walaupun terdapat puncak sebanyak 200 orang-hari dalam tahun ke- 9 dan ke-10, ketika penyadapan dimulai dan pemanenan buah dalam sistem wanatani karet (Wulan dkk. 2008). Upah harian yang dilaporkan untuk pekerja pertanian di desa dekat kota Malinau adalah Rp 60.000-70.000 yang berada di atas rerata nasional (wawancara dengan Ibu Ros, anggota Pemberdayaan dan Kesejahteraan Keluarga/PKK). Di desa yang lebih

Tabel 7. Hasil panen dan harga pohon buah-buahan

\begin{tabular}{|c|c|c|c|c|c|}
\hline Jenis buah & $\begin{array}{l}\text { Umur } \\
\text { panen } \\
\text { pertama }\end{array}$ & $\begin{array}{l}\text { Hasil panen } \\
\text { tahunan per pohon } \\
\text { di kebun }\end{array}$ & $\begin{array}{l}\text { Harga rata-rata } \\
\text { tingkat petani, } \\
\text { Malinau, } 2012\end{array}$ & $\begin{array}{l}\text { Harga rata-rata } \\
\text { eceran, Kalimantan } \\
\text { Timur, } 2011^{\text {a }}\end{array}$ & $\begin{array}{l}\text { Referensi (panen } \\
\text { dan hasil pertama) }\end{array}$ \\
\hline Durian & 7-8 tahun & $\begin{array}{l}8-13 \text { tahun }=40 \mathrm{~kg} \\
14-25 \text { tahun }=80 \mathrm{~kg} \\
\text { atau } 50-100 \text { buah }\end{array}$ & $\begin{array}{l}\text { Rp } 25.000 \text { untuk } \\
1 \text { buah }\end{array}$ & $\begin{array}{l}\text { Rp } 95.700 \text { untuk } 1 \\
\text { buah }\end{array}$ & $\begin{array}{l}\text { FAO 2007; ICRAF } \\
2013\end{array}$ \\
\hline Rambutan & 8 tahun & $\begin{array}{l}8-15 \text { tahun }= \\
10-42 \mathrm{~kg} \\
16-25 \text { years }=45- \\
300 \mathrm{~kg}\end{array}$ & $\begin{array}{l}\text { Rp } 10.000 \text { untuk } \\
1 \text { kg }\end{array}$ & Rp 9.945 untuk 1 kg & $\begin{array}{l}\text { Tindall 2004; ICRAF } \\
2013\end{array}$ \\
\hline Petai & 7 tahun & 200-500 kulit buah & Tidak diketahui & Tidak diketahui & $\begin{array}{l}\text { Subhadrabandhu } \\
\text { 2001; Abdullah dkk } \\
2011 \text {; ICRAF } 2013\end{array}$ \\
\hline
\end{tabular}

a Sumber: Kantor Statistik Provinsi: http://kaltim.bps.go.id/web/publikasi lain/harga perdesaan/ 
terpencil di luar Malinau, upah harian adalah sekitar Rp 50.000 ditambah makanan.

Sistem RAS-2 biasanya tidak menggunakan pupuk, walaupun pupuk dapat mendukung pertumbuhan pohon karet, khususnya apabila dilakukan dalam 2-4 tahun pertama. Kebutuhan pupuk lebih besar apabila padi akan ditumpangsarikan juga. Hasil uji coba sistem RAS-2 di Kalimantan menyarankan penambahan $100 \mathrm{~g}$ urea per pohon sampai akhir tahun keempat (Ilahang dkk. 2006). Rerata harga eceran urea tanpa subsidi adalah Rp 5.173/kg di Kalimantan Timur; sementara urea bersubsidi jauh lebih murah yaitu Rp 1.600 (Rahmad 2011).

Rambutan membutuhkan pupuk selama empat penebaran yang sama setiap 3 bulan selama 4 tahun pertama (ICRAF 2013). Untuk pohon berbuah dianjurkan sebanyak $200 \mathrm{~g}$ nitrogen, $25 \mathrm{~g}$ fosfor dan $130 \mathrm{~g}$ kalium per pohon per tahun usia. Tingkat pupuk maksimum dicapai saat 12 tahun dan harus tetap konstan setelahnya.

Pupuk khususnya tidak digunakan pada durian (Morton 1987; Brown 1997; ICRAF 2013), walaupun aplikasi bulanan $5 \mathrm{~g} /$ pohon dengan formula lengkap 6-6-6 sampai pohon mencapai kematangan bisa bermanfaat (Morton 1987). Takaran ini setara dengan $60 \mathrm{~g}$ per pohon per tahun atau $3 \mathrm{~kg}$ per 50 pohon per tahun sampai tahun produksi ke-14. Pupuk biasanya tersedia dalam kemasan $50 \mathrm{~kg}$.

Asam semut dibutuhkan untuk merawat lateks. Berdasarkan hasil yang diharapkan dengan sistem RAS-2, rerata 23 botol per hektar per tahun dibutuhkan mulai pada tahun ke-8 (setelah pohon mencapai umur penyadapan). Angka ini dihitung untuk wanatani karet berdasarkan rerata jumlah botol yang diperlukan per tahun penyadapan untuk monokultur karet (Leimona dan Joshi 2010), berdasarkan fakta bahwa hasil tahunan rerata DRC adalah 24,2\% lebih rendah dengan RAS-2 (Wulan dkk. 2008) dibandingkan untuk monokultur karet (Leimona dan Joshi 2010).

\section{Ukuran botol asam semut bervariasi} antarprodusennya, namun kurang lebih dibutuhkan $4 \mathrm{ml}$ asam semut untuk $1 \mathrm{~kg}$ karet, yang akan mengasilkan $500 \mathrm{~g}$ DRC (http://rubberboard. org.in/ManageCultivation. asp?Id = 192). Sebotol asam semut $25 \mathrm{~kg}$ saat ini harganya $\mathrm{Rp} 312.500$ (http://www.cvputeradaradjat.web.id/_item?item_ $\mathrm{id}=016002)$. Jika harga asam semut terlalu tinggi, petani bisa menggunakan koagulasi alami tetapi harus menghindari penggunaan asam sulfat, tawas atau kaolin, yang mencemari dan merusak produk akhir (Peramune dan Afs 2007).

Persepsi masyarakat dan pemangku kepentingan tingkat kabupaten tentang biaya dan manfaat wanatani karet disajikan pada Tabel 8. Diskusi dengan pemangku kepentingan tingkat kabupaten berpusat pada kelayakan untuk menerapkan strategi tersebut di Setulang.

Manfaat langsung yang utama, menurut pengamatan kedua kelompok pemangku kepentingan adalah kesejahteraan ekonomi yang secara keseluruhan meningkat karena diversifikasi mata pencaharian dan produksi panen menghasilkan uang tunai (karet). Manfaat lain yang dirasakan adalah meningkatnya ketahanan terhadap bencana iklim karena karet dan wanatani dapat menahan tekanan-tekanan banjir dan kekeringan dengan lebih baik dibandingkan tanaman tahunan (misalnya, padi) dan akan berkontribusi pada diversifikasi tanaman yang tersedia untuk uang tunai dan konsumsi langsung sepanjang tahun.

Pemanfaatan wanatani karet juga diharapkan untuk merehabilitasi lahan terdegradasi yang jika tidak, akan terbiarkan kosong untuk beberapa waktu, dan untuk mengendalikan erosi (manfaat tambahan yang diperhatikan oleh pemangku kepentingan tingkat kabupaten). Karena pengelolaan wanatani karet dianggap tidak membutuhkan banyak waktu, para pemangku kepentingan menyoroti manfaat tambahan lain, yaitu masih ada waktu untuk mengerjakan kegiatan-kegiatan pertanian atau mata pencaharian lainnya. Biaya operasional karet juga dipandang rendah, khususnya jika dibandingkan dengan biaya operasi dan distribusi yang tinggi untuk perkebunan kelapa sawit berskala kecil.

Anggota masyarakat Setulang juga mencatat pentingnya memanfaatkan produksi karet sebagai sumber pendapatan yang menarik untuk mendorong kaum muda agar tinggal di desa, suatu manfaat yang terkait dengan kesejahteraan ekonomi desa secara keseluruhan. Para pemangku kepentingan tingkat kabupaten tidak menyebutkan faktor ini namun mencatat bahwa pengembangan karet akan sangat mungkin mengurangi perladangan berpindah sehingga, akan mengurangi deforestasi juga. Hal ini tidak serta merta berlaku bagi penduduk Setulang di mana praktik-praktik pertaniannya tidak 
Tabel 8. Biaya dan manfaat wanatani karet, menurut anggota masyarakat dan pemangku kepentingan tingkat kabupaten

\begin{tabular}{|c|c|c|c|}
\hline & Deskripsi & $\begin{array}{l}\text { Persepsi anggota } \\
\text { masyarakat }\end{array}$ & $\begin{array}{l}\text { Persepsi para pemangku kepentingan } \\
\text { tingkat kabupaten }\end{array}$ \\
\hline \multirow[t]{6}{*}{ Manfaat } & $\begin{array}{l}\text { Kesejahteraan ekonomi di desa secara } \\
\text { umum meningkat. }\end{array}$ & Ya & Ya \\
\hline & $\begin{array}{l}\text { Lahan terdegradasi diperbaiki dan } \\
\text { erosi dikendalikan. }\end{array}$ & $\mathrm{Ya}$ & Ya \\
\hline & Kaum muda tetap tinggal di desa. & $\mathrm{Ya}$ & Tidak \\
\hline & $\begin{array}{l}\text { Penguatan penghidupan dan } \\
\text { ketahanan pangan selama bencana } \\
\text { iklim. }\end{array}$ & $\mathrm{Ya}$ & Ya \\
\hline & $\begin{array}{l}\text { Penduduk memiliki lebih banyak } \\
\text { waktu luang (perawatan karet tidak } \\
\text { intensif). }\end{array}$ & Ya & Ya \\
\hline & $\begin{array}{l}\text { Perladangan berpindah menurun, } \\
\text { demikian pula dengan deforestasi. }\end{array}$ & Tidak & Ya \\
\hline \multirow[t]{8}{*}{ Biaya } & Bibit & $\mathrm{Ya}$ & Ya \\
\hline & Tenaga kerja & $\mathrm{Ya}$ & Ya \\
\hline & \multirow{2}{*}{$\begin{array}{l}\text { Waktu: jasa penyuluhan dan } \\
\text { pengembangan kapasitas }\end{array}$} & \multirow[t]{2}{*}{ Ya } & Ya \\
\hline & & & $\begin{array}{l}\text { Biaya besar karena terbatasnya } \\
\text { kapasitas teknis untuk budidaya karet }\end{array}$ \\
\hline & \multirow[t]{2}{*}{ Lahan } & Ya & Ya \\
\hline & & Dianggap banyak & $\begin{array}{l}\text { Dianggap langka karena perlindungan } \\
\text { terhadap Tane' Olen dan konflik } \\
\text { perbatasan }\end{array}$ \\
\hline & $\begin{array}{l}\text { Kegiatan pemasaran dan } \\
\text { pengembangan kapasitas }\end{array}$ & Tidak & $\mathrm{Ya}$ \\
\hline & Lebih banyak konflik antardesa & Tidak & Ya \\
\hline
\end{tabular}

menyebabkan deforestasi Tane' Olen atau wilayah berhutan lainnya, namun bisa jadi berlaku untuk wilayah lainnya di Malinau.

Pemangku kepentingan tingkat kabupaten mencermati bahwa biaya utamanya selain asupan seperti bibit dan tenaga kerja adalah alokasi lahan, mengingat banyak wilayah Setulang yang merupakan hutan lindung atau digunakan untuk pertanian dan permukiman. Kebanyakan lahan yang tersedia berdekatan dengan batas yang dipersengketakan dengan desa-desa lain. Sebaliknya, anggota masyarakat tidak menganggap lahan adalah langka, karena masing-masing rumah tangga dapat mencadangkan 1 ha dari lahan mereka saat ini untuk implementasi strategi. Bagi masyarakat, ketersediaan lahan lebih merupakan isu terkait dengan generasi mendatang.

Waktu dan sumber daya yang dibutuhkan anggota masyarakat untuk mempelajari teknik wanatani karet yang baru memunculkan biaya lain, bagi anggota masyarakat sendiri dan instansi di kabupaten, seperti dinas perkebunan dan dinas pemberdayaan masyarakat. Biaya ini dipandang sebagai kendala utama untuk mengadopsi intervensi. Sejumlah dinas saat ini sedang menghadapi kelangkaan sumber daya, khususnya staf yang terampil. Mengingat kurangnya pengalaman tentang karet secara umum, dinas-dinas tersebut lebih mendorong budidaya kakao dan kopi. Tidak ada lokasi percontohan untuk karet, namun dinas perkebunan berencana untuk mengembangkannya. Namun demikian, penduduk desa Setulang telah bekerja dengan banyak LSM dan organisasi penelitian selama beberapa tahun sehingga mereka cepat belajar dan seharusnya akan mampu dengan mudah mengadopsi strategi, walaupun tenaga penyuluh tetap akan dibutuhkan.

Beberapa dinas kabupaten menyampaikan bahwa pemasaran karet akan sulit karena karet merupakan komoditas baru di kabupaten ini. Namun penduduk 
Desa Setulang mengatakan bahwa pembeli karet pernah datang sebelumnya.

Namun demikian, implementasi strategi wanatani karet mungkin berdampak tidak langsung dalam memperburuk konflik. Desa lain mungkin akan iri dengan peningkatan ekonomi atau kesejahteraan di Setulang akibat intervensi, khususnya mengingat mereka mungkin menggunakan lahan yang juga diklaim oleh desa-desa lain.

\subsubsection{Usaha kecil kerajinan tangan rotan}

Perempuan di Setulang memiliki tradisi panjang membuat berbagai kerajinan tangan dari rotan, termasuk keranjang, topi tradisional, tas dan barangbarang rumah tangga, seperti piring (Gambar 15). Penduduk desa kebanyakan membuatnya untuk dipakai sendiri dan sebagian kecil dijual ke beberapa turis yang mengunjungi desa mereka. Sumber daya rotan tersedia di Tane' Olen dan pengkajian barubaru ini (Sidiyasa dkk. 2006) menemukan banyak spesies rotan dengan jumlah berlimpah. Namun demikian, selama lokakarya dengan masyarakat, penduduk melaporkan bahwa sumber daya ini telah mulai menurun, walaupun belum pada laju yang mengkhawatirkan. Apabila tidak dipanen dari hutan, rotan dapat tumbuh tanpa perlu upaya besar di lahan kosong, bersama-sama dengan vegetasi yang tumbuh alami, seperti dicermati oleh Belcher dkk. (2004).

Membangun usaha kecil kerajinan tangan rotan akan melibatkan pembangunan kapasitas, seperti melalui pelatihan untuk mengembangkan desain dan

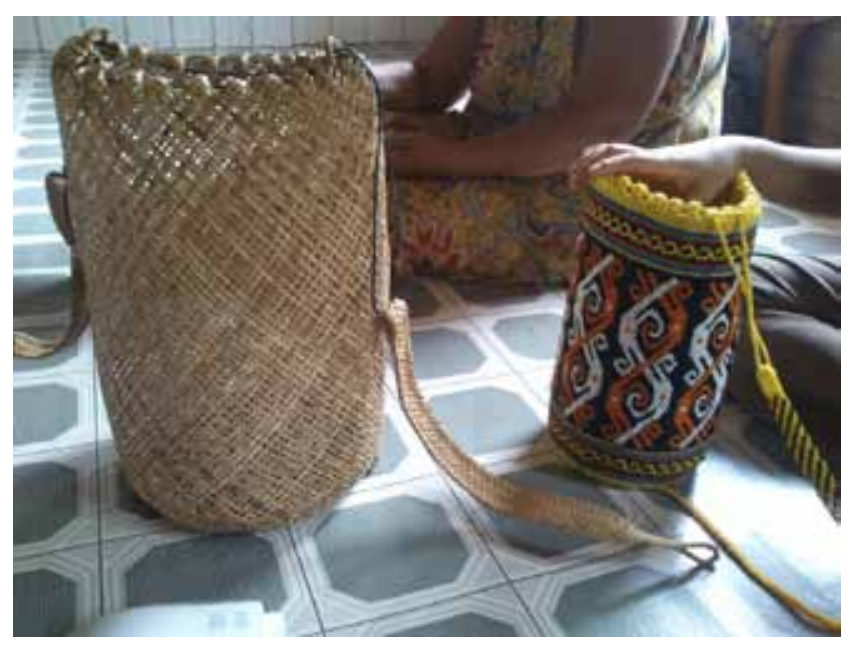

Gambar 15. Keranjang yang dibuat oleh perempuan Setulang

Sumber: Hangga Prihatmaja pemasaran kerajinan tangan, membentuk pasar desa sebagai tempat penjualan kerajinan tangan kepada turis dan pengunjung lain dan untuk mendorong hasil-hasil di luar hutan melalui saluran seperti dijelaskan di bawah ini.

Produk-produk yang dihasilkan dapat diberi label berasal dari Tane' Olen. Hutan Setulang yang dilindungi dapat membentuk merek yang kuat dan khas di Kalimantan dan di luar negeri. Kerajinan Tane' Olen yang dipasarkan akan selaras dengan rencana ekoturisme terkait hutan dan tradisi-tradisi adat.

Terdapat sejumlah organisasi pemerintah maupun nonpemerintah yang dapat memberikan pelatihan yang dibutuhkan. Program Pertukaran Hasil Hutan Bukan Kayu/Non-Timber Forest Products Exchange Programme (http://www.ntfp.org) memberikan pelatihan tentang pembentukan dan pengelolaan usaha kecil kerajinan tangan di Kalimantan dan luar negeri. WWF Malinau memberikan pelatihan berdasarkan permintaan tentang penjualan produk-produk rotan untuk masyarakat setempat yang berminat dan telah pula melaksanakan pelatihan khusus kerajinan tangan di Krayan.

Dinas Perindustrian dan Kerja sama kabupaten membuka pusat pelatihan di Kuala untuk mendukung pengembangan industri kerajinan tangan rotan dengan fokus pada mebel modern (seperti didiskusikan selama wawancara pemangku kepentingan tingkat kabupaten). Mereka saat ini bekerja dengan beberapa seniman dari Jawa untuk pelatihan desain.

Pusat pelatihan memiliki ruang pameran yang dapat digunakan masyarakat untuk memamerkan kerajinan tangan mereka, sementara dinas berusaha mendorong penduduk desa agar bergeser dari produksi untuk penggunaan pribadi dan rumah tangga menjadi strategi dan pola pikir yang lebih pada produksi untuk usaha berskala kecil. Karena saat ini produksi hanya ditujukan untuk penggunaan pribadi, masyarakat tidak memberikan perhatian pada estetika kerajinan tangan dan tidak menyadari potensi nilai ekonomi pada sektor-sektor seperti mode dan desain interior.

Dinas dapat menyiapkan modal untuk memulai pembinaan bagi masyarakat. Mereka juga membangun jaringan kerja pembeli untuk kerajinan tangan masyarakat. Saat ini, dinas hanya dapat memamerkan kerajinan tangan di pusat pelatihan 
mereka dan pada saat pameran, namun sangat sedikit penduduk desa yang berminat untuk memamerkan kerajinan tangan mereka pada saat pameran. Upayaupaya pemasaran akan lebih diperluas dengan bantuan dinas untuk kerja sama dan perdagangan dan organisasi-organisasi lain yang tertarik.

Organisasi lain tidak hanya bisa memberikan pelatihan desain kerajinan tangan bagi anggota masyarakat, tapi juga yang membeli dan membantu memasarkan hasil-hasil akhir termasuk Threads of Life (http://www.threadsoflife.com/fairtrade.asp), Pekerti Nusantara (Indonesian People's Handicraft Foundation Marketing Service; http://pekerti.com/ about.php), the Rattan Project dan Yayasan Pecinta Budaya Bebali (http://www.ypbb.org/contactus.htm). Forum Fair Trade Indonesia juga berusaha untuk mempromosikan perdagangan di Indonesia dan meningkatkan akses pasar bagi produsen lokal.

Para pembuat kerajinan memberlakukan harga yang berbeda untuk barang produksinya, bergantung pada pembeli dan tujuan akhir produknya. Selama wawancara lanjutan, kami mengetahui bahwa perempuan di Setulang menjual tas tradisional, keranjang (anjat) dan topi (sa'ong) seharga Rp 50.000 kepada pembeli dari desa lain; harga lebih tinggi apabila kerajinan tangan ini dijual langsung kepada turis. Tikar tidur sederhana $(70 \times 120 \mathrm{~cm})$ dapat dijual sampai $\mathrm{Rp}$ 400.000. Studi-studi terdahulu yang dilaksanakan di Kalimantan Timur menunjukkan bahwa marjin keuntungan produsen untuk tikar rotan dapat berkisar dari 115\% sampai 519\% (Purnama dkk. 1998). Keranjang rotan dapat terjual mencapai 60 dolar AS melalui ajang pameran dagang yang memasarkan produk ke konsumen luar negeri (misalnya, SERRV, www.serrv.org/product/ rattan-basket-set/baskets? refid=truefairtrade). Sekitar $20 \%$ dari harga eceran ini langsung diterima oleh produsen yang akan dikonversi menjadi sekitar Rp 116.000 per potong, bergantung pada penjual dan pengaturan pemasaran.

Banyak perempuan yang sudah menjadi anggota PKK yang aktif di desa Setulang. Oleh karena itu mereka dapat dengan mudah terhubung dengan organisasi tersebut. Masyarakat juga dapat meminta bantuan Satgas (lihat Bab 4.2.4) di bawah program Gerdema untuk membantu aspek-aspek teknis, logistik dan finansial dalam mengembangkan usaha kecil kerajinan tangan.
Dalam hal biaya, bahan baku (rotan dan pewarna natural) biasanya tersedia secara bebas sebagai barang bersama dari hutan Tane' Olen di mana pengelolaan HHBK di dalamnya secara lestari merupakan prioritas. Perempuan Setulang menyampaikan bahwa apabila mereka tidak memiliki waktu untuk mengumpulkan rotan dari hutan atau ada hambatan fisik yang menghalangi, mereka selalu dapat membeli ikatan rotan dari tetangga atau desa-desa lain. Satu ikat rotan cukup untuk menganyam satu keranjang seharga Rp 5.000-15.000.

Perempuan tidak selalu memiliki waktu karena pekerjaan lain mereka di sawah. Banyak yang biasanya membuat kerajinan tangan di waktu luang seperti selama periode setelah panen padi. Jika dibuat hanya selama ada waktu luang, sebuah keranjang anjat membutuhkan waktu penyelesaian sampai sebulan (wawancara dengan Ibu Yurita, anggota PKK). Namun demikian, beberapa kelompok perempuan membuat dan menjual kerajinan tangan sepanjang tahun; mereka juga sering menjual kerajinan tangan dari yang lain jika yang bersangkutan tidak punya waktu untuk menjualnya sendiri.

Dalam hal strategi wanatani karet, masyarakat dan para pemangku kepentingan tingkat kabupaten menyebutkan beberapa biaya dan manfaat (Tabel 9). Diskusi dengan para pemangku kepentingan tingkat kabupaten sekali lagi berfokus pada kelayakan untuk menerapkan strategi di Setulang.

Menjual kerajinan tangan rotan dapat menyediakan sumber pendapatan yang penting, khususnya bagi perempuan jika kelebihan hasil panen tidak cukup untuk dijual. Selain itu, perempuan dapat membuat kerajinan tangan ketika luang, atau mereka yang tidak bekerja di sawah dapat membuatnya dengan biaya peluang yang lebih rendah. Namun, pemangku kepentingan tingkat kabupaten menyoroti biaya transportasi dan distribusi serta kapasitas masyarakat setempat jika terlibat dalam pemasaran berskala lebih besar di luar produksi untuk penggunaan pribadi atau rumah tangga.

Kedua kelompok pemangku kepentingan memperhatikan bahwa kurangnya keterampilan kerajinan tangan kaum muda adalah hambatan yang utama untuk implementasi. Banyak anggota masyarakat yang lebih muda yang berfokus pada pendidikan mereka, melakukan kegiatan lain 
Tabel 9. Biaya dan manfaat penjualan kerajinan tangan rotan, menurut anggota masyarakat dan pemangku kepentingan tingkat kabupaten

\begin{tabular}{|c|c|c|c|}
\hline & Deskripsi & $\begin{array}{l}\text { Disebutkan oleh } \\
\text { anggota masyarakat }\end{array}$ & $\begin{array}{l}\text { Disebutkan } \\
\text { oleh pemangku } \\
\text { kepentingan tingkat } \\
\text { kabupaten }\end{array}$ \\
\hline \multirow[t]{4}{*}{ Manfaat } & $\begin{array}{l}\text { Perempuan memiliki peluang mata pencaharian } \\
\text { alternatif sepanjang tahun (terlepas dari kondisi iklim } \\
\text { dan hasil panen). }\end{array}$ & Ya & Tidak \\
\hline & $\begin{array}{l}\text { Kesejahteraan ekonomi di desa secara umum } \\
\text { meningkat. }\end{array}$ & Ya & Ya \\
\hline & $\begin{array}{l}\text { Identitas budaya khas Setulang menjadi lebih } \\
\text { dikenal. }\end{array}$ & Ya & Tidak \\
\hline & $\begin{array}{l}\text { Pengalaman pengunjung/turis bertambah lewat } \\
\text { kunjungan ke pasar kerajinan tangan. }\end{array}$ & Ya & Tidak \\
\hline \multirow[t]{4}{*}{ Biaya } & $\begin{array}{l}\text { Pelatihan untuk meningkatkan desain dan } \\
\text { pemasaran kerajinan tangan. }\end{array}$ & Ya & Ya \\
\hline & Tenaga kerja (waktu). & Ya & Tidak \\
\hline & Pengumpulan (waktu) atau pembelian (uang) rotan. & Ya & Tidak \\
\hline & Transportasi dan distribusi. & Tidak & Ya \\
\hline
\end{tabular}

atau memandang pertanian telah cukup untuk menghidupi mereka. Untuk kebutuhan rumah tangga mereka sendiri, kaum muda lebih suka membeli tikar dan keranjang dari tetangga atau desa lain. Pelatihan dapat membantu meningkatkan kesadaran kaum muda tentang peluang menarik terkait dengan perdagangan, mode dan desain interior serta membantu mereka memperoleh keuntungan dari peluang ini.

\subsubsection{Kemampuan untuk menghadapi ancaman iklim utama}

Skenario iklim di masa mendatang tidak pasti. Karena itu ketidakpastian ini yang membuat kekuatan dari intervensi adaptasi yang diusulkan dianalisis mengingat ancaman iklim utama di masa mendatang. Kondisi iklim tertentu atau ambang batas yang terjadi ketika intervensi gagal atau tidak efektif harus spesifik untuk identifikasi kerentanan tambahan yang bisa terjadi (dan mengembangkan rencana untuk menindaklanjutinya). Analisis juga membantu untuk menentukan indikator peringatan dini yang dapat diikutsertakan pada pengelolaan adaptif ketika implementasi dimulai.

Intervensi penjualan kerajinan tangan rotan tidak menunjukkan risiko kegagalan di bawah kemungkinan skenario iklim apa pun karena rotan bersumber dari Tane' Olen, hutan yang relatif tidak terganggu dan dikelola secara lestari sehingga tidak rentan terhadap kebakaran hutan. Namun demikian, suatu ambang batas iklim dan biofisik tertentu perlu dipantau terkait sistem wanatani karet.

Seperti digambarkan pada Bab 5.1, ancaman iklim utama di masa depan bagi Malinau adalah:

- suhu

- kenaikan rerata tahunan dan musiman (sangat mungkin)

- kenaikan jumlah hari dengan suhu maksimum lebih dari $35^{\circ} \mathrm{C}$ (mungkin)

- curah hujan

- kenaikan jumlah hari dengan curah hujan di atas $300 \mathrm{~mm}$ (mungkin)

- kejadian ekstrem

- peningkatan frekuensi dan intensitas kejadian ENSO (mungkin).

Studi tentang kerentanan karet terhadap bencana iklim masih langka dan sebagian besar berasal dari Thailand dan Malaysia. Karet tumbuh pada kisaran suhu $22-35^{\circ} \mathrm{C}$ (Sdoodee dan Rongsawa 2012) meskipun suhu pertumbuhan optimalnya adalah $25-28^{\circ} \mathrm{C}$.

Produksi karet membutuhkan curah hujan setidaknya $2.000 \mathrm{~mm} /$ tahun yang didistribusikan secara merata dan tidak mengganggu penyadapan 
dan pengumpulan lateks. Periode kering sampai selama 1 bulan dapat ditoleransi dengan baik, namun perpanjangan periode kering dapat menyebabkan hasil panen berkurang (Sdoodee dan Rongsawa 2012). Akibatnya, ancaman utama untuk produksi karet adalah panjangnya kekeringan yang disebabkan ENSO dan curah hujan tinggi yang menyebabkan kerusakan akibat banjir. Kombinasi suhu yang lebih tinggi dan peningkatan curah hujan juga dapat menyebabkan lebih banyak wabah dan hama penyakit karet.

Untuk menekan dampak kekeringan selama periode pembentukan, tanaman polibag yang sudah dewasa dengan sistem akar yang baik dapat dipindahkan untuk penanaman dalam diikuti dengan pemulsaan menggunakan jerami padi (Rodrigo dkk. 2011). Kandungan potasium yang tinggi pada jerami padi akan membantu meringankan setiap stres kelembaban pada tanaman.
Suhu iklim dan curah hujan yang ekstrem dapat berpengaruh buruk pula bagi produktivitas pohon buah-buahan. Durian, sebagai contoh, tumbuh paling baik dengan suhu tahunan rerata $22^{\circ} \mathrm{C}$ dan curah hujan tahunan rerata $1.500-2.000 \mathrm{~mm}$ (ICRAF 2013). Tanah harus dikeringkan dengan baik untuk membatasi kerugian karena pembusukan akar. Rambutan, di sisi lain, memiliki toleransi yang lebih tinggi dan dapat berkembang dengan suhu rerata tahunan sampai $35^{\circ} \mathrm{C}$, tetapi tidak menyukai genangan air.

Namun demikian, penggunaan sistem wanatani untuk memproduksi karet dapat menekan risiko penurunan hasil panen karena produksi akan mengalami diversifikasi dan siklus hara akan ditingkatkan. Langkah-langkah tambahan seperti irigasi dan saluran drainase mungkin dibutuhkan untuk mencegah kerusakan dari kekeringan serta curah hujan yang tinggi. 


\section{Kaitan dengan REDD+}

\subsection{Adaptasi dan Mitigasi}

Strategi adaptasi dan mitigasi umumnya berbeda dalam sasaran dan skala spasial mereka. Mitigasi memiliki manfaat global yang mewujud dalam jangka panjang sedangkan adaptasi terutama terkait masalah lokal dengan manfaat lebih langsung pada skala lokal (Locatelli 2011). Namun, proyek mitigasi dapat berdampak positif atau negatif bagi kapasitas adaptasi masyarakat, dan proyek-proyek adaptasi bisa mendukung atau menghambat tujuan mitigasi (Locatelli dkk. 2011). Kaitan ini khususnya terlihat pada sektor pertanian dan kehutanan, khususnya pada intervensi seperti REDD+. Perhatian juga terus meningkat tentang eksplorasi cara-cara agar adaptasi dan migitasi dapat dilakukan secara simultan untuk memungkinkan strategi menangmenang dan dampaknya pada sektor-sektor tersebut (Locatelli 2011).

Sebagai contoh, proyek-proyek REDD+ dapat berkontribusi bagi adaptasi hutan terhadap perubahan iklim dengan mengurangi tekanan degradasi dan kerentanan hutan, menjaga keanekaragaman hayati dan meningkatkan kesinambungan ekosistem untuk penguatan ketahanan (Fischlin dkk. 2007). Hal-hal ini dapat berdampak positif (misalnya, meningkatkan penyediaan jasa ekosistem, diversifikasi pendapatan dan kegiatan ekonomi dan memperkuat kelembagaan lokal) atau dampak negatif (misalnya, membatasi akses ke sumber daya hutan dan ketergantungan pada pendanaan eksternal) bagi kapasitas masyarakat lokal untuk beradaptasi dengan perubahan iklim (Sunderlin dkk. 2009; Caplow dkk. 2011; Larson 2011).

Proyek-proyek adaptasi dapat berkontribusi bagi penyerapan dan penyimpanan karbon melalui restorasi ekosistem atau tindakan-tindakan seperti wanatani. Adaptasi perubahan iklim yang dianggap berhasil dalam bidang pertanian dapat mengurangi degradasi tambahan atau konversi hutan sehingga berkontribusi bagi mitigasi global dan tujuantujuan REDD+ (Locatelli dkk. 2011). Di sisi lain, kurangnya adaptasi atau implementasi dari intervensi yang tidak ditargetkan dengan baik dapat menyebabkan degradasi hutan atau konversi yang lebih besar, meningkatkan kerentanan hutan (misalnya, meningkatnya risiko kebakaran selama kekeringan) dan akhirnya menghambat upaya-upaya untuk mencapai target REDD+.

Memaksimalkan sinergi dan memahami serta meminimalkan imbal balik antara REDD+ dan adaptasi masyarakat lokal akan memastikan bahwa REDD+ berkontribusi bagi prioritas nasional dan juga dalam memberikan manfaat untuk orang-orang yang miskin dan rentan (Graham 2011). Penerapan pendekatan ini untuk REDD+ dan adaptasi dapat mendorong terwujudnya 'tiga kemenangan' (triple wins) dari pembangunan yang sejalan dengan iklim: menjaga emisi tetap rendah, membangun ketahanan terhadap dampak perubahan iklim dan mendukung pembangunan (Mitchell dan Maxwell 2010).

Untuk wilayah Malinau, kaitan antara keberhasilan implementasi REDD+ dan dua intervensi adaptasi berbasis masyarakat yang dianalisis di atas dapat ditelusuri melalui dua skenario: (1) keberlanjutan situasi saat ini, yang dicirikan oleh strategi-strategi eksploitasi dan penanggulangan; atau (2) skenario masa depan alternatif di mana kondisi kedua intervensi adaptasi telah mencapai hasil yang dimaksudkan. Kaitan yang digambarkan di bawah ini adalah berdasarkan pada analisis desktop dan konsultasi pemangku kepentingan dan yang relevan bagi masyarakat yang bergantung pada hutan di wilayah kabupaten. Beberapa hal dianalisis secara lebih mendalam menggunakan bukti dari studi lapangan yang dilaksanakan di tempat lain.

\subsection{Skenario dengan Strategi Penanggulangan saat ini dan Eksploitasi yang Tidak Berkelanjutan}

Di Malinau, beberapa tantangan yang saling bertautan dapat berdampak pada hutan dan ketahanannya dan akibatnya bagi pencapaian sejumlah sasaran REDD+. Konflik dan tenurial lahan yang tidak jelas menghambat investasi, baik di kabupaten maupun masyarakat dalam pengelolaan hutan dan sumber daya secara lestari dan intervensi 
pertanian seperti wanatani. Ketiadaan investasi pertanian (khususnya yang memiliki manfaat adaptasi), tekanan iklim dan bencana seperti banjir dan kekeringan dapat mengurangi hasil panen atau bahkan menyebabkan kegagalan panen. Kondisi ini dapat memaksa masyarakat untuk membuka lahan yang lebih besar di dataran tinggi atau mengambil lebih banyak sumber daya hutan, seperti kayu, babi hutan dan HHBK untuk menambah pemasukan mereka (strategi penanggulangan). Kurangnya diversifikasi dan konflik atas sumber daya di masa lalu telah menyebabkan degradasi HHBK yang penting, seperti gaharu dan sarang burung (Moeliono dkk. 2009). Kegagalan mengambil tindakan-tindakan untuk mengatasi hal ini dapat memperbesar masalah.

Lemahnya kepastian tenurial memungkinkan pertambangan dan pembalakan terjadi secara ekstensif dan tidak terkontrol, bahkan di wilayahwilayah yang sebelumnya dianggap tidak dapat diakses. Intensifikasi industri telah mengurangi kapasitas adaptif masyarakat, melalui polusi dan sedimentasi sungai, meningkatnya kerentanan hutan dan berkurangnya akses ke sumber daya hutan. Selain itu, populasi ikan telah menurun, yang merupakan sumber protein utama di wilayah ini, walaupun penduduk lebih suka memakan daging babi hutan yang bernilai tinggi secara kultural. Namun, babi hutan diketahui sulit dijumpai setelah pembalakan, sebagian besar karena penebasan tumbuhan bawah (setelah pemanenan kayu). Penebasan di petak bekas tebangan terbukti menggangu masyarakat setempat dan menurunkan keanekaragaman hayati hutan (Sheil dkk. 2009).

Kurangnya insentif untuk pengelolaan hutan secara lestari meningkatkan kerentanan hutan terhadap perubahan iklim (misalnya, meningkatkan risiko kebakaran). Tanpa perencanaan tata guna lahan terpadu dan lintas sektoral, tampaknya organisasi pemerintah dan sektor swasta sulit untuk saling terikat dalam pengelolaan hutan lestari. Ketidakpastian tenurial juga menyulitkan keterlibatan masyarakat dalam tindakan-tindakan proaktif dan kolaboratif, seperti pemantauan hutan dan pengurangan risiko kebakaran partisipatif. Insentif untuk menerima kompensasi uang tunai dari pertambangan atau konsesi pembalakan bahkan menjadi lebih kuat daripada untuk pengelolaan hutan lestari, khususnya bagi kaum muda.

Organisasi pengamat dan LSM juga mencatat bahwa pembentukan provinsi baru Kalimantan Utara dapat meningkatkan risiko deforestasi hutan alam Malinau
(Parker 2013). Sebagian besar kekayaan Kalimantan Timur berasal dari industri ekstraktif di bagian selatan provinsi. Kabupaten yang telah menjadi bagian dari Kalimantan Utara tidak akan lagi menerima dividen dari industri ekstraktif dan pejabat baru yang mencari dana baru dapat mengeluarkan izin baru untuk pertambangan, pembalakan dan perkebunan.

Sebagaimana terlihat di bagian dunia lainnya, setelah bencana biasanya mereka yang miskin dan memiliki sumber daya yang tidak pasti adalah mereka yang bergantung pada sumber daya hutan (Pramova dkk. 2012). Di Malawi, sebagai contoh, hutan penting untuk strategi adaptasi reaktif, khususnya untuk rumah tangga yang tidak memiliki pilihan lain, namun hutan tidak termasuk dalam adaptasi antisipatif (Fisher dkk. 2010). Penelitian lain di Malinau telah menemukan bahwa orang yang terkena dampak banjir menjual atau memakan daging babi liar dari hutan untuk menambah pendapatan dan makanan mereka (Liswanti dkk. 2011). Semantara di Honduras, rumah tangga miskin perdesaan menjual kayu setelah tidak mampu untuk menutup kepemilikan lahan yang hilang karena badai Mitch (McSweeney 2005).

Karena itu penting sekali untuk membedakan antara produk-produk sebagai jaring pengaman untuk strategi penanggulangan (jangka pendek, biasanya setelah terjadinya bencana) dan produk-produk sebagai sumber utama diversifikasi mata pencaharian untuk strategi adaptasi (pengelolaan sumber daya proaktif dalam mengantisipasi bencana). Masyarakat termiskin dari yang miskin mungkin akan beralih ke hutan selama atau setelah bencana untuk bertahan hidup, tetapi beberapa petani juga memanfaatkan hutan dan hasil-hasil hutan sebagai strategi diversifikasi pendapatan terpadu untuk menghadapi variabilitas iklim secara berkelanjutan. Banyak dari masyarakat agraris yang memelihara pohon di ladang mereka untuk tujuan ini. Ketika panen gagal karena kejadian iklim, mereka dapat menjual kayu dan hasil hutan bukan kayu dari pertanian mereka untuk menambah penghasilan (Pramova dkk. 2012).

Dengan strategi penanggulangan seperti yang ditemui di Honduras dan Malinau, ketergantungan yang tinggi terhadap hutan selama kejadian iklim dapat menimbulkan kerentanan ketika ekosistem terdegradasi atau tidak dikelola dengan baik, ketika konflik muncul antara pengguna hutan atau ketika akses menjadi terbatas. Nilai masa depan aset-aset alami dan bagaimana masyarakat dapat 
memanfaatkannya di bawah REDD+ merupakan kekhawatiran yang dicermati (Peskett dkk. 2008). Sejalan dengan pertumbuhan penduduk dan sebagai respon atas pembangunan atau tekanan iklim, REDD+ dapat menyebabkan situasi di mana masyarakat tidak dapat bergantung pada asetaset alami seperti yang mereka miliki sebelumnya - sebagai contoh, untuk pendapatan uang tunai dari pembalakan, sebagai jaring pengaman ketika terjadi guncangan dan sebagai sebuah sumber lahan pertanian (Graham 2011). Bencana dapat memaksa masyarakat untuk mengabaikan komitmen mereka terhadap REDD+. Oleh karena itu penting untuk untuk meningkatkan kapasitas adaptif masyarakat dan mengintegrasikan strategi adaptasi ke dalam perencanaan REDD+ untuk mendorong transisi yang efektif dari penanggulangan ke adaptasi.

\subsection{Skenario dengan Adaptasi dan Pengelolaan yang Berkelanjutan}

Strategi adaptasi berbasis masyarakat seperti wanatani karet dan bisnis kerajinan tangan akan bermanfaat bagi hutan maupun masyarakat hanya jika mereka mencapai sasarannya dan penduduk mengelola tantangan dan potensi dari konsekuensi yang tidak diharapkan dengan tepat.

Tantangan pertama untuk diatasi adalah konflik sosial dan kebutuhan untuk menjernihkan tenurial lahan. Seperti digambarkan pada Bab 4.1 dan 4.2, konflik dan ketidakpastian tenurial merupakan hambatan utama bagi pengembangan pertanian lokal. Namun demikian, apabila masyarakat memiliki insentif yang lebih besar untuk investasi dalam pengelolaan sumber daya dan pertanian dan strategi diversifikasi seperti wanatani karet dan penjualan kerajinan tangan rotan, mata pencaharian mereka akan diperkuat dan menjadi lebih tangguh, seperti halnya ekosistem hutan di sekitar mereka. Insentif ini akan berkontribusi bagi penurunan deforestasi, khususnya pada kasus ketika perladangan berpindah dapat menjadi masalah atau ketika anggota masyarakat yang lebih muda cenderung untuk memperbolehkan eksploitasi industri untuk memperoleh kompensasi sebagai timbal baliknya.

Proyek-proyek adaptasi dapat berdampak positif secara tidak langsung pada kegiatan-kegiatan REDD+ apabila mereka mencegah perpindahan kegiatan dan deforestasi yang ditimbulkan. Contohnya, jika intervensi adaptasi pertanian mendukung produktivitas tanaman dan penghidupan serta mengurangi pembukaan hutan untuk perluasan pertanian (Locatelli 2011). Walaupun bukti dari kaitan ini dalam literatur perubahan iklim masih langka, beberapa studi mengamati hubungan antara praktik-praktik seperti wanatani dan pengelolaan hutan berbasis masyarakat (yang relevan untuk adaptasi) dan pengurangan deforestasi (relevan untuk REDD+) di luar perdebatan perubahan iklim.

Potensi wanatani untuk meningkatkan pendapatan perdesaan, meningkatkan ketahanan terhadap bencana iklim dan mengembalikan lahan kritis telah didokumentasikan dengan baik (Verchot dkk. 2007; Garrity dkk, 2010; Pramova dkk. 2012). Namun, wanatani juga dapat memiliki efek langsung dan tidak langsung pada mitigasi perubahan iklim melalui penyerapan karbon dan pengurangan deforestasi. Program Alternatif Perladangan Berpindah mencatat potensi penyerapan dan penyimpanan karbon pada berbagai sistem wanatani (Verchot dkk. 2007). Konversi tanaman baris atau lahan peternakan menjadi sistem wanatani dapat sangat meningkatkan jumlah karbon yang disimpan dalam biomasa di atas tanah karena sistem wanatani memiliki 50-75 $\mathrm{mg} /$ ha karbon, sementara tanaman baris memiliki kurang dari $10 \mathrm{mg} /$ ha karbon. Tumpangsari dengan pohon buah-buahan dan sistem wanatani yang lain juga telah diyakini lebih menguntungkan dibandindingkan monokultur dengan masa bera yang pendek dan tanaman baris, yang merupakan fokus khas dari program-program intensifikasi pertanian (Gockowski dkk. 2001).

Namun demikian, pemerintah di banyak negara tropis telah mendorong intensifikasi pertanian sebagai pengganti sistem pertanian-ekologis dan perladangan berpindah yang lebih sederhana dengan tujuan untuk meningkatkan produksi pangan, meningkatkan pendapatan petani dan melindungi hutan dari pembukaan yang ekstensif (Lin dkk. 2008; van Vliet dkk. 2012). Tren ini berkontribusi pada keyakinan yang tersebar luas bahwa pohon berdampak negatif pada tanaman pangan karena kompetisi untuk air dan hara. Namun, penelitian menunjukkan bahwa intensifikasi yang direncanakan secara buruk sebenarnya memperparah kerentanan terhadap perubahan iklim (Lin dkk. 2008) dan dapat menyebabkan deforestasi tetap dengan akibat yang parah bagi jasa ekosistem dan kesuburan tanah (van Vliet dkk. 2012). Di bawah pendekatan alternatif untuk intensifikasi wanatani, intensifikasi pertanian terjadi dalam kaitannya dengan pohon, 
dengan sasaran melestarikan jasa ekosistem dan meningkatkan pendapatan petani (Steffan-Dewenter dkk. 2007).

Sistem wanatani dapat bermanfaat untuk keanekaragaman hayati dan adaptasi hutan karena berfungsi sebagai koridor biologis dan mengurangi tekanan manusia atas hutan alam (Schroth 2004; Bhagwat 2008). Hal ini menunjukkan bahwa sistem wanatani merupakan rumah bagi lebih banyak spesies dibandingkan sistem monokultur (Bhagwat 2008). Oleh karena itu, produksi wanatani, bahkan di pinggiran hutan, dapat bermanfaat bagi masyarakat maupun hutan.

Studi dari Taman Nasional Kerinci Seblat di Sumatera, Indonesia, menunjukkan bahwa rumah tangga yang memiliki kebun campuran dengan pohon, mengekstrasi lebih sedikit sumber daya dari taman nasional dibandingkan rumah tangga yang hanya membudidayakan padi sawah (Murniati dkk. 2001). Situasi yang sama juga dijumpai di sekitar Cagar Alam Nyungwe di Rwanda (Masozera dan Alavalapati 2004). Penelitian di pulau kecil di Pasifik juga telah menunjukkan bahwa keberadaan pohon-pohon berharga untuk penghidupan di luar hutan secara signifikan mengurangi deforestasi dan degradasi hutan di dalam kawasan cagar alam tersebut (Bhagwat dkk. 2008).

Rotan dapat berfungsi sebagai sebuah alat pengelolaan risiko yang berharga karena merupakan sumber tabungan atau penerimaan yang berdaya hidup lama dan membutuhkan sedikit pemeliharaan. Karena itu masyarakat tidak hanya dapat menggunakannya saat dibutuhkan namun juga untuk diversifikasi sepanjang tahun melalui pembuatan dan penjualan kerajinan tangan (Pambudhi dkk. 2004). Ini khususnya penting dalam sistem tanpa strategi atau kelembagaan pengelolaan risiko yang lain (misalnya, rekening bank dan polis asuransi). Ketika ada kebutuhan darurat untuk uang tunai, rotan sudah tersedia dan 'tabungan rotan' dapat dilikuidasi setiap saat karena periode pemanenannya sangat fleksibel dan batang rotan tumbuh sepanjang tahun dengan sedikit atau tanpa pengelolaan (Belcher dkk. 2004). Cara ini memberikan alternatif yang mungkin dikerjakan dan efektif, dari pilihan yang ada yaitu menebang pohon untuk kayunya atau membiarkan lahan untuk konsesi. Namun, ini hanya mungkin jika tersedia pasar untuk menjual rotan mentah, yang dalam kenyataannya sangat terbatas di Malinau. Membuat dan menjual produk rotan membutuhkan waktu meski tidak mengurangi peran penting mereka dalam strategi diversifikasi mata pencaharian.

Keberadaan aset yang lebih banyak dan lebih beragam (termasuk aset alami, fisik, finansial, manusia dan sosial) menguatkan kapasitas adaptif di tingkat lokal (Plummer dan Armitage 2010). Cara-cara implementasi REDD+ akan memengaruhi aset-aset masyarakat tersebut. Sebagai contoh, memastikan tenurial dan menerapkan strategi diversifikasi mata pencaharian, seperti pengembangan usaha kecil kerajinan tangan rotan, dapat dimanfaatkan sebagai peluang untuk mendidik masyarakat lokal tentang pengelolaan hutan lestari (termasuk pengelolaan HHBK seperti rotan), pemasaran kerajinan tangan, serta pemantauan, pelaporan dan verifikasi berbagai kegiatan REDD+. Oleh karena itu modal sumber daya manusia akan terbentuk dengan dampak positif pada kapasitas adaptif (Graham 2011). Namun demikian, masyarakat lokal hanya dapat menjadi pengelola hutan yang efektif ketika hak-hak mereka diakui, ada cara untuk partisipasi yang berarti, biaya dan manfaat pengelolaan hutan terbagi secara adil dan ada dukungan eksternal yang memadai (Cronkleton dkk. 2008).

Manfaat sinergis lebih lanjut dapat dicapai dari implementasi bersama REDD + dan strategi adaptasi untuk mengoptimalkan dampak keseluruhan. Sebagai contoh, jaringan dan keuangan REDD+ dapat digunakan untuk menyampaikan informasi iklim dan pengetahuan yang relevan untuk adaptasi masyarakat agraria serta untuk adaptasi hutan secara tepat waktu (Graham 2011). Informasi semacam itu dapat diintegrasikan ke dalam model tata kelola dan pengelolaan adaptif yang hasil intervensinya dipantau, dikelola dan disesuaikan kembali secara terus-menerus sesuai dengan perubahan situasi dan kebutuhan (misalnya, perubahan pemicu deforestasi dan degradasi dan tekanan-tekanan perubahan iklim). Dalam kondisi ketidakpastian, pengelolaan adaptif seharusnya menjadi landasan untuk intervensi apapun. 


\section{Analisis Biaya-Manfaat dan Rentabilitas Sosial}

\subsection{Analisis Biaya-Manfaat}

Mengingat nilai moneter untuk analisis SROI yang lengkap tidak dapat dihitung karena kurangnya data yang tersedia, analisis biaya-manfaat (CBA) untuk masing-masing strategi (wanatani karet dan kerajinan tangan rotan) diterapkan, berdasarkan potensi masukan dan keluaran. Data terbaik yang tersedia digunakan untuk CBA, bersumber dari literatur, kantor-kantor statistik (misalnya, Badan Statistik Provinsi) dan pernyataan para pemangku kepentingan yang disampaikan selama lokakarya dan wawancara. Namun demikian, data tersebut tidak optimal dan hasilnya harus ditafsirkan secara hatihati. Untuk alasan ini, digunakan prakiraan yang paling konservatif (misalnya, hasil rerata terendah dan harga rerata masukan yang paling tinggi) seperti diuraikan pada Bab 6.2.

Untuk strategi wanatani karet, analisis didasarkan pada tumpang sari 550 pohon karet dengan 100 pohon durian di atas 30 tahun. Jenis-jenis pohon buah lainnya dapat dipadukan, namun data untuk hasil panen rambutan, sebagai contoh, tidak dapat disimpulkan (lihat Tabel 7). Panen karet diprakirakan berdasarkan pada data sistem RAS-2 dalam Wulan dkk. (2008) menghasilkan rerata panen tahunan DRC sebesar $1.131 \mathrm{~kg} / \mathrm{ha}$. Hasil panen rerata DRC oleh Wulan dkk. (2008) digunakan sampai tahun ke-18. Persentase pengurangan hasil pada tahun berikutnya dihitung menurut Belcher dkk. (2004). Untuk menghitung pendapatan, rerata harga di tingkat petani untuk DRC sebesar Rp 4.000/kg digunakan sebagai prakiraan dalam pengkajian USAID atas rantai nilai industri karet di Indonesia (Peramune dan Afs 2007).

Panen durian diprakirakan secara konservatif sebesar 20 pohon per tahun (sekitar $40 \mathrm{~kg}$ ) untuk semua tahun. Panen optimum yang dapat diperoleh dari kebun yang baik biasanya dua kali lipat jumlah itu (80 kg per pohon per tahun). Harga di tingkat petani untuk satu buah telah ditetapkan sekitar Rp 25.000.

Semua masukan tenaga kerja dan pupuk dihitung seperti dijelaskan pada Bab 6.2.1. Untuk urea, digunakan harga eceran pupuk urea yang disubsidi di Kalimantan Timur (Rp 5.173/kg). Rerata upah harian yang lebih tinggi di Malinau digunakan (Rp 70.000) seperti yang dilaporkan pada saat wawancara lanjutan di desa (wawancara, Ibu Ros). Tingkat suku bunga rerata di Indonesia untuk tahun 2005-2013 (7,8\%) (www.tradingeconomics. com/indonesia/interest-rate) digunakan untuk mendiskonto nilai untuk tahun-tahun mendatang.

Biaya di awal cukup tinggi selama beberapa tahun pertama, untuk menutupi tenaga kerja, pupuk dan bibit (Rp 12.284.515 pada tahun ke-1, Rp 7.284.515 pada tahun ke-2, Rp 4.134.515 pada tahun ke-3), tetapi setelah arus kas positif dimulai pada tahun ke-8, keuntungan cukup besar. Dengan asumsi skenario terbaik untuk tingkat panen setiap tahun dan penjualan semua produk, petani dapat memperoleh keuntungan sebesar Rp 40.095.000Rp 48.019.810. Karena ini bisa menjadi sedikit tidak realistis, CBA untuk skenario kedua dihitung dengan masukan dan biaya tetap sama, tetapi panen dan pendapatan yang terkait dengan karet dan durian berkurang sebesar $50 \%$ sepanjang tahun. Bahkan di bawah skenario yang lebih realistis ini, keuntungan tetap cukup besar: mencapai $\mathrm{Rp}$ 12.995.000Rp 21.198.900 dengan asumsi semua produk terjual. Nilai bersih saat ini dari skenario ini adalah Rp 96.745.055.

CBA untuk strategi kerajinan tangan rotan didasarkan pada produksi dua barang per bulan (oleh masing-masing rumah tangga atau perempuan) sehingga tidak mengganggu kegiatan lain dan untuk mempertahankan biaya peluang tenaga kerja/waktu agar tetap nol. Sayangnya, biaya pelatihan untuk desain dan pemasaran tidak dapat dihitung. Satusatunya biaya yang diperhitungkan adalah untuk membeli seikat rotan (Rp 15.000). Oleh karena itu CBA untuk strategi ini masih tidak lengkap, namun telah ada sejumlah kepastian bahwa tidak terdapat aliran uang tunai yang negatif (atau keuntungan bersih yang negatif) bagi rumah tangga/perempuan yang membuat kerajinan tangan rotan. Bahkan ketika sejumlah ikat rotan harus dibeli, barang kerajinan tangan dapat dijual setidaknya seharga Rp 50.000 ke desa lain atau lebih mahal untuk turis atau ajang 
pameran perdagangan (setidaknya Rp 116.000 per barang). Keuntungan dapat ditingkatkan dengan membuat tikar (misalnya, mencapai Rp 400.000, menurut penduduk desa).

Namun, analisis harus memperhitungkan kemungkinan tahun-tahun yang buruk ketika panen gagal atau tidak satupun produk terjual. Sistem produksi juga dapat rusak karena kebakaran atau kejadian ekstrem yang lain, dan harga pada tingkat petani dapat turun secara drastis. Meskipun demikian, risiko terkait kedua strategi relatif rendah dan implementasinya hanya bisa menambahkan manfaat. Selain itu karena lahan di Setulang masih berlimpah, wanatani karet tidak terlalu membutuhkan pekerja dan kerajinan tangan rotan dapat dibuat pada waktu-waktu luang. Manfaat untuk adaptasi, kebanyakan terkait dengan diversifikasi dan peningkatan kapasitas, juga merupakan hal penting, demikian juga dengan manfaat nonmaterial bagi masyarakat, seperti mempertahankan generasi muda tetap di desa dan mempromosikan budaya Setulang di luar kabupaten. 


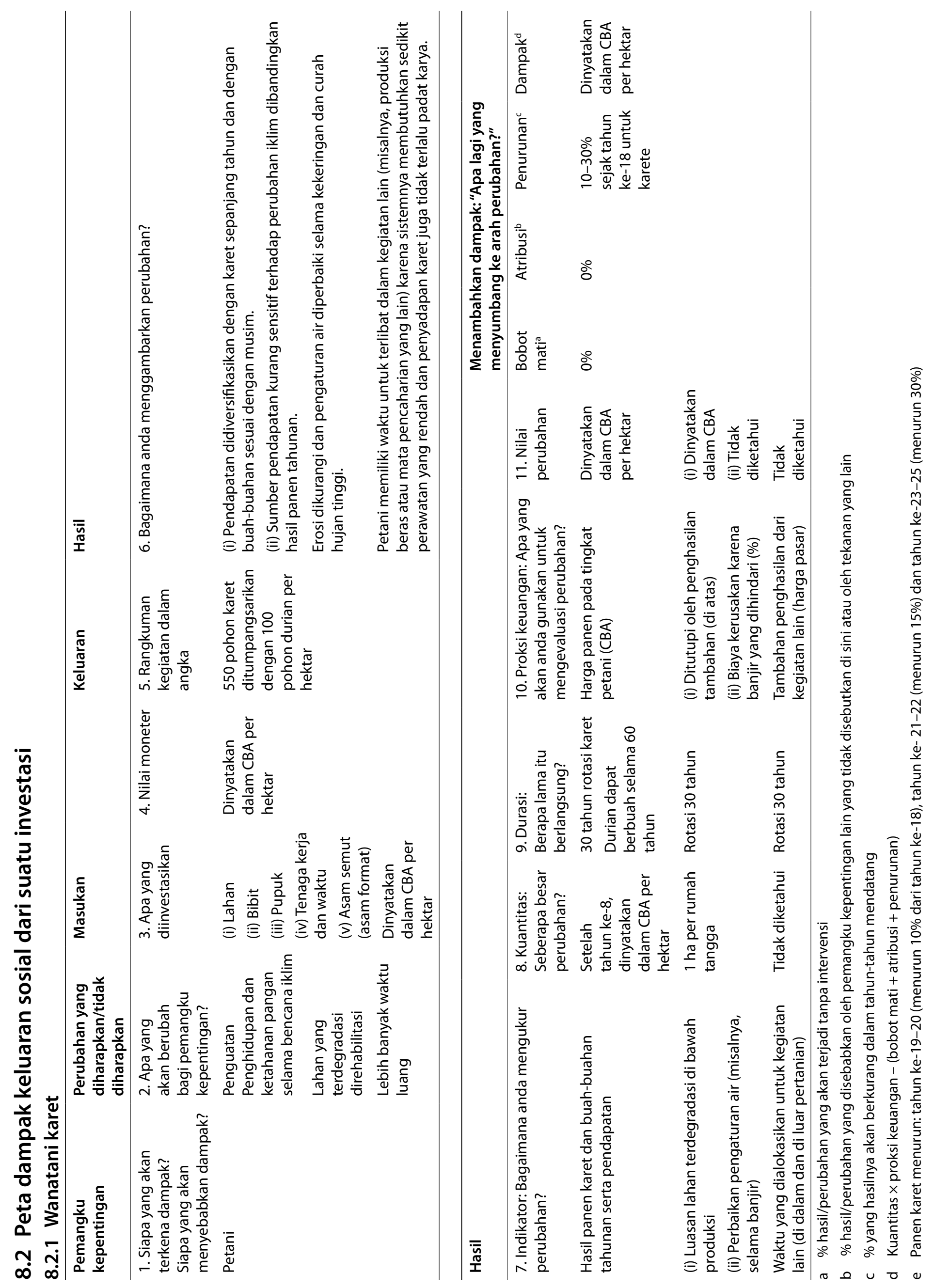




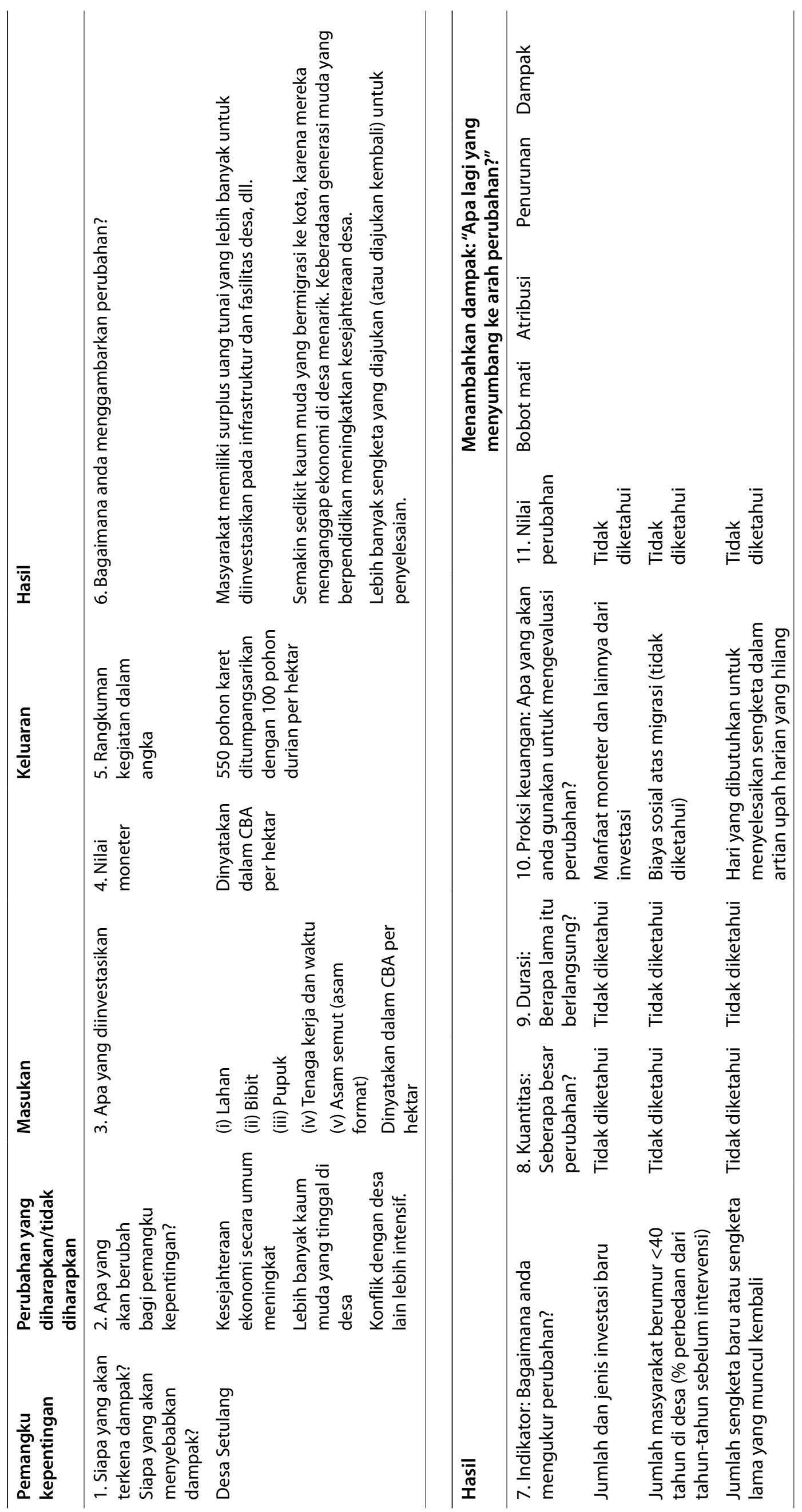




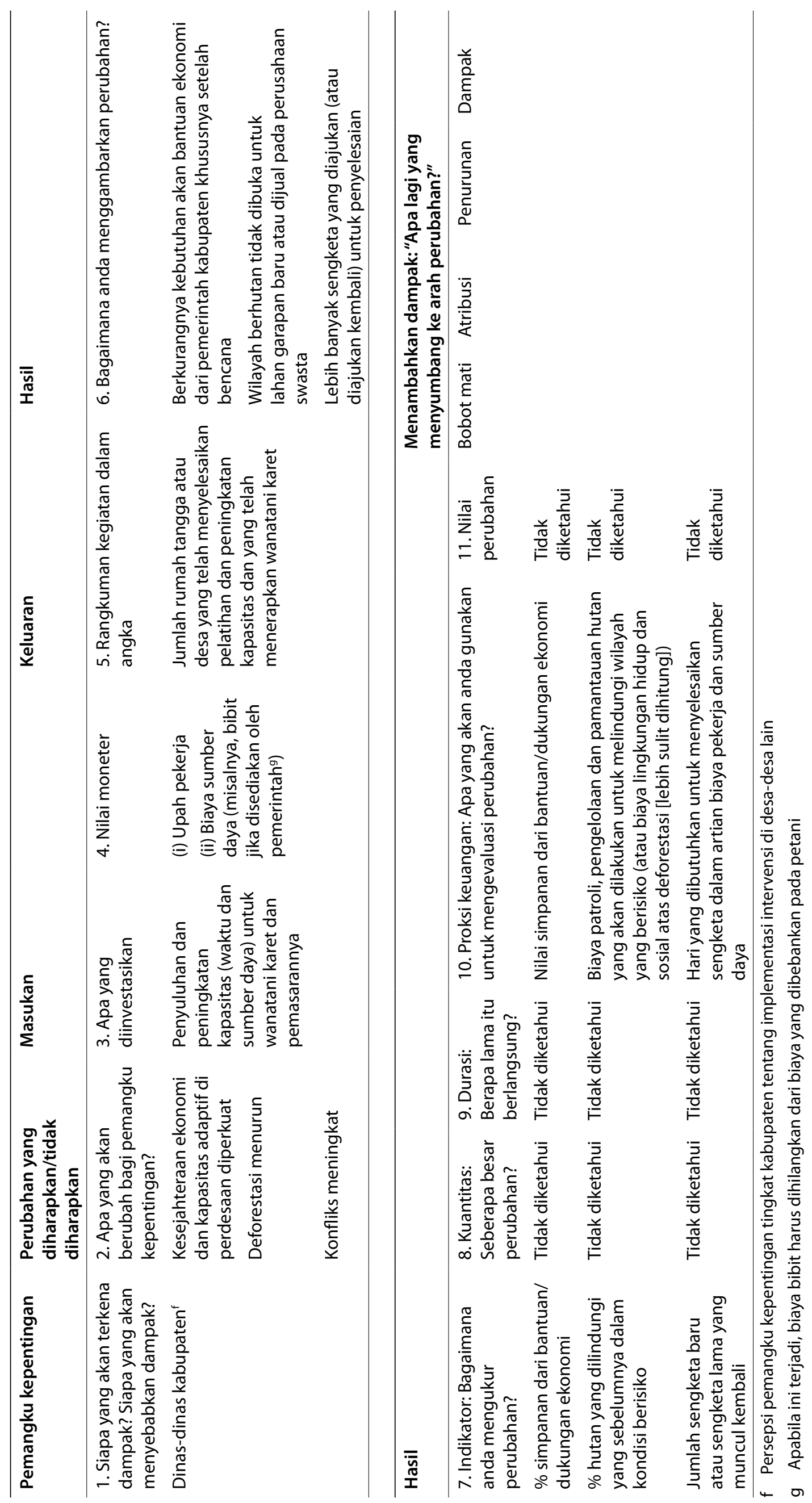




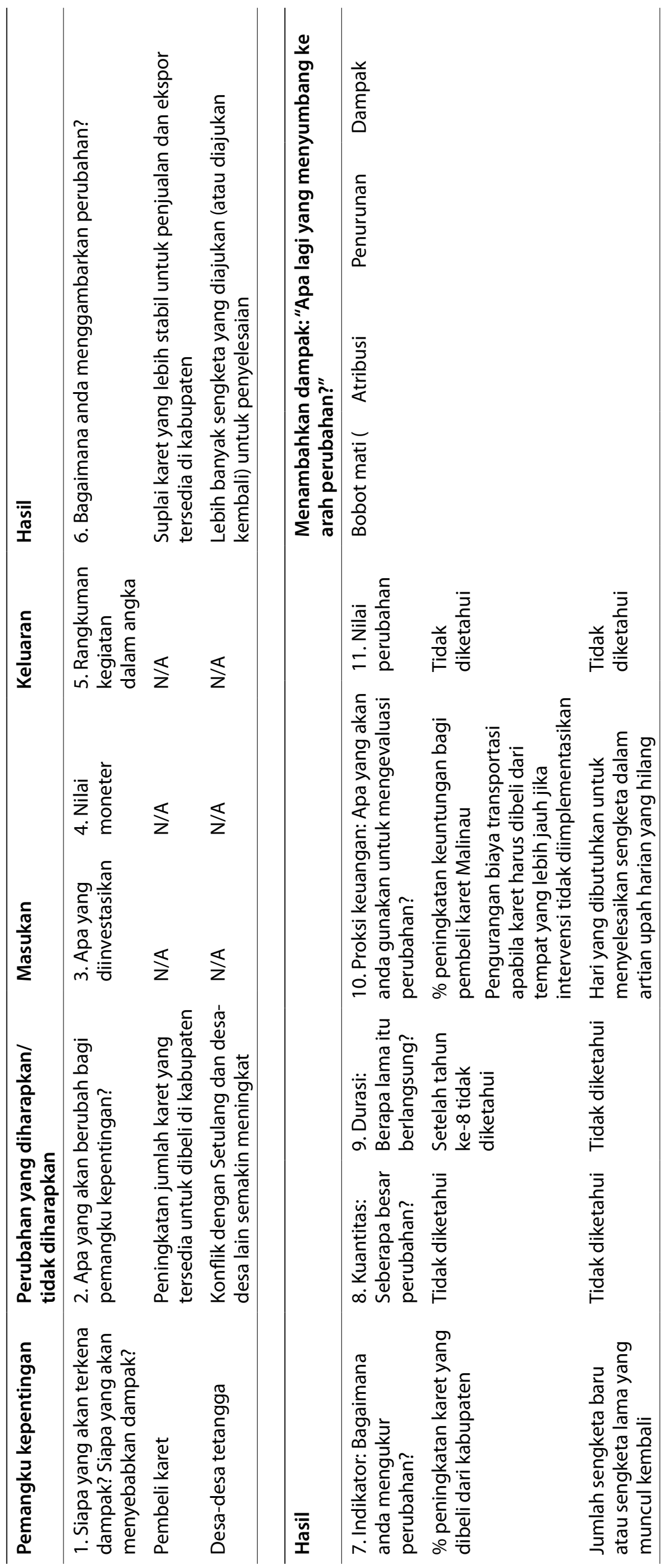




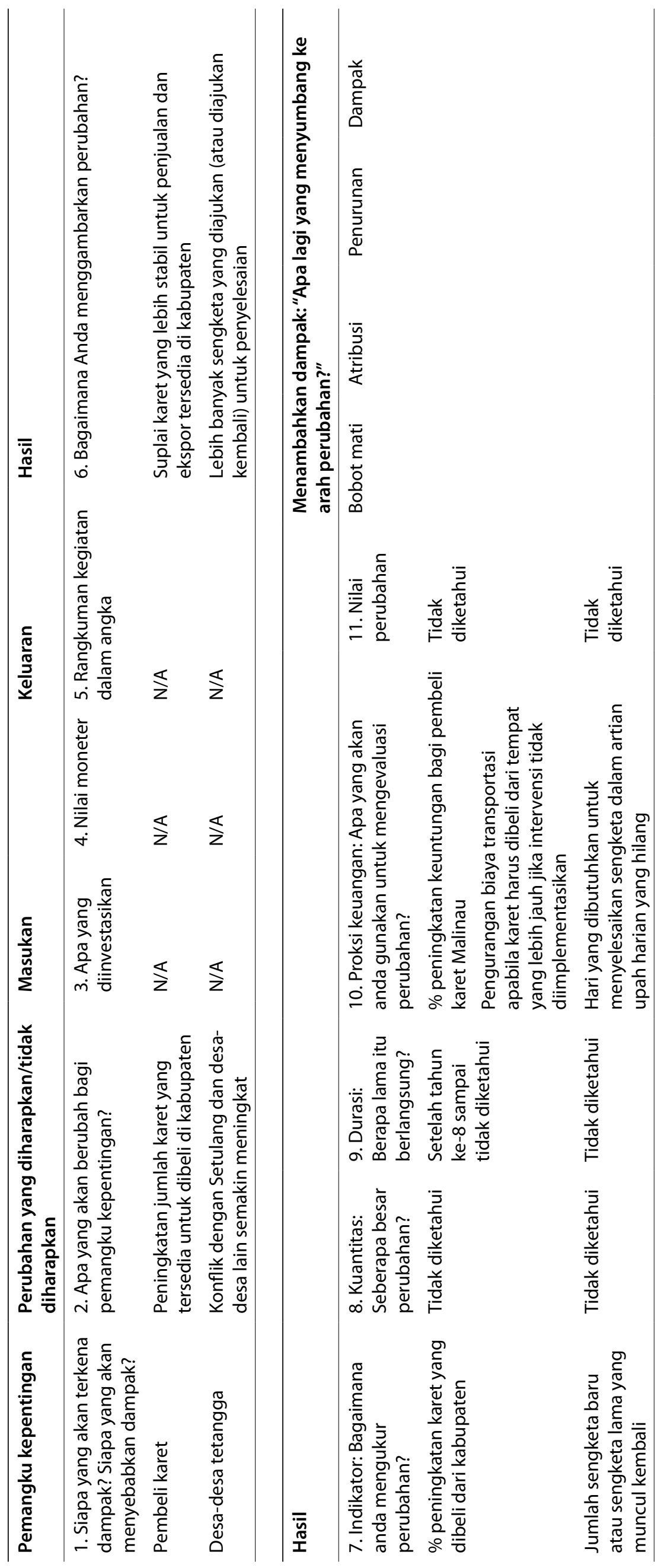




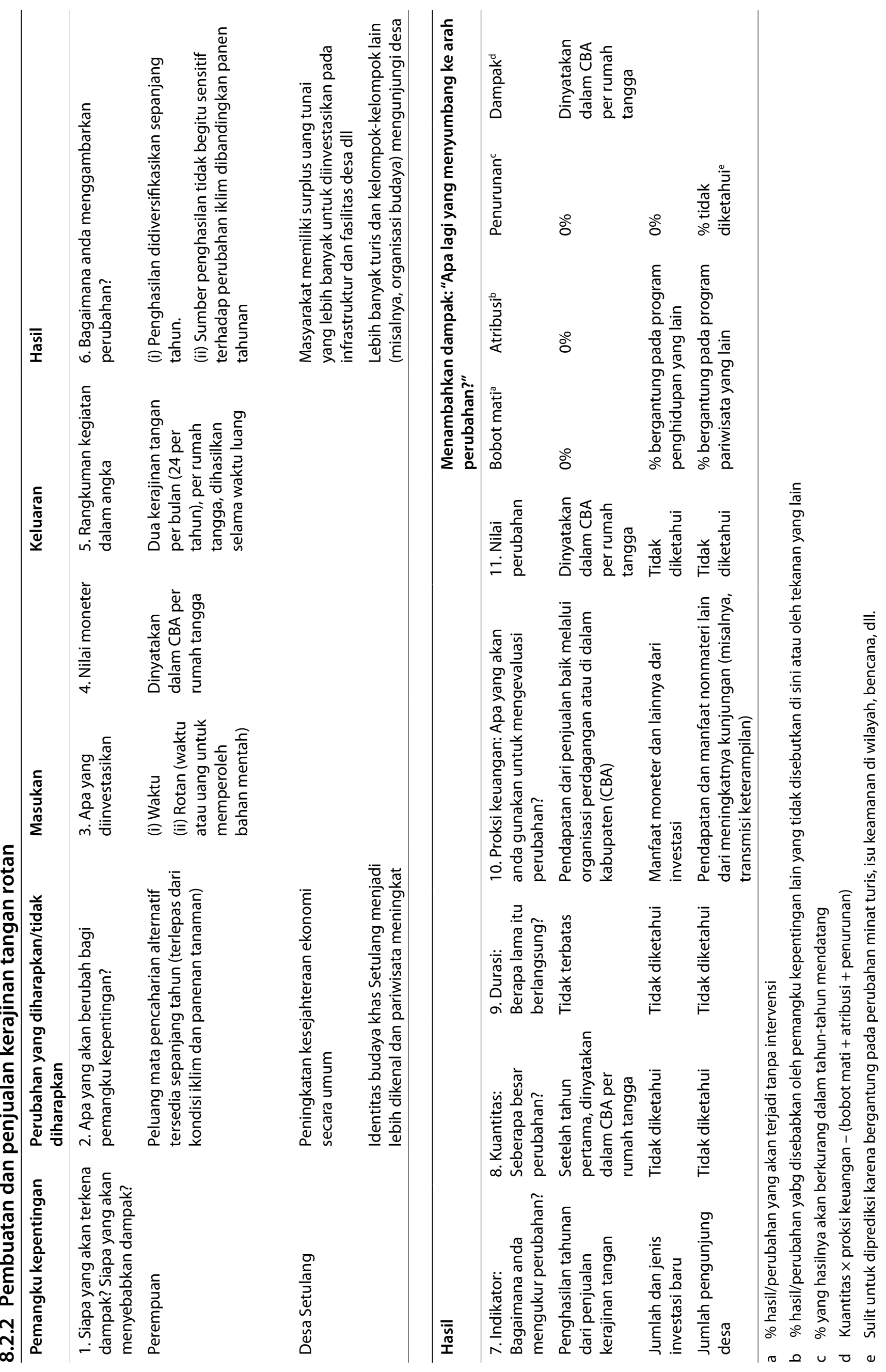




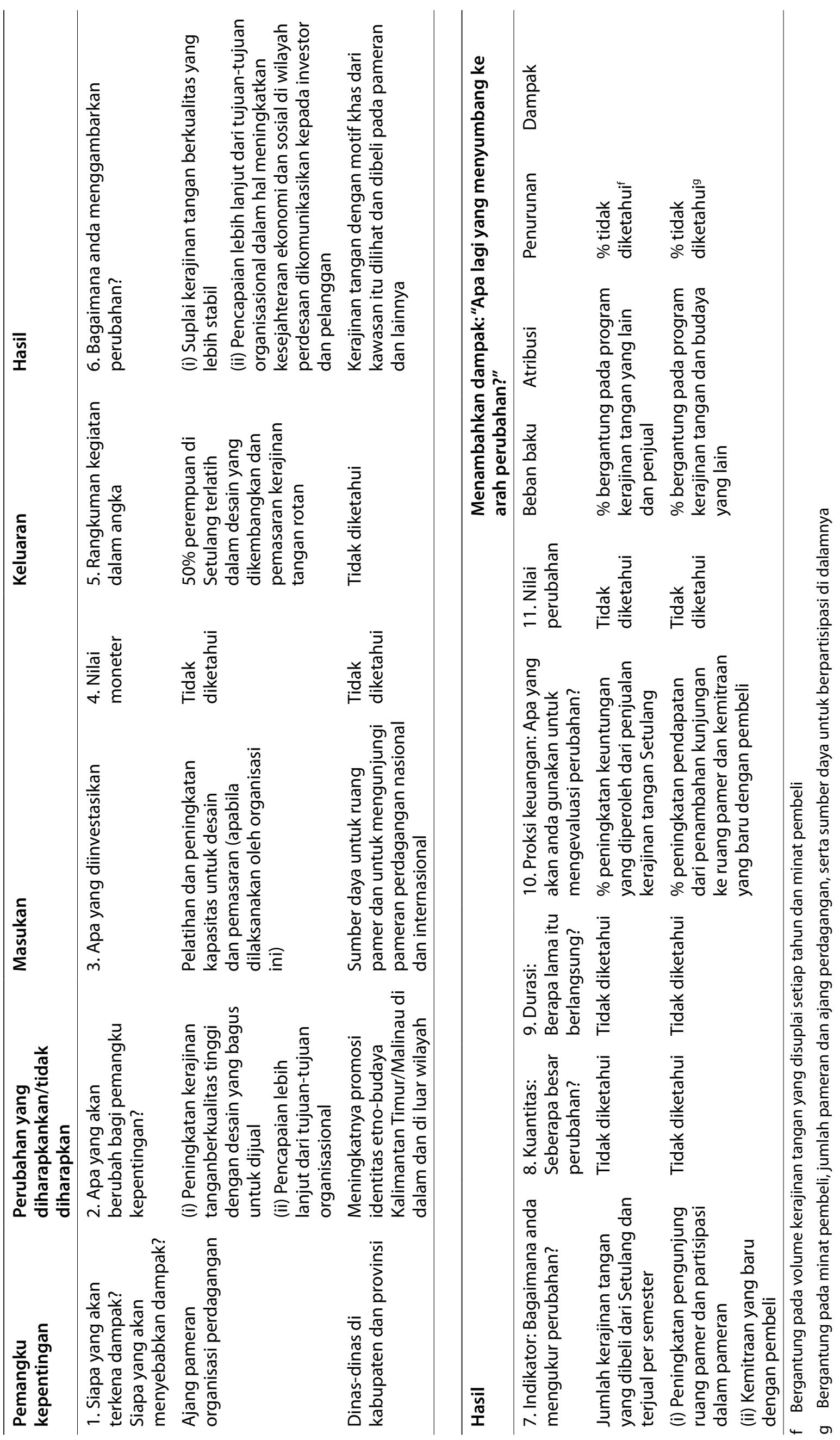




\section{Daftar Pustaka}

Abdullah MHR, Ch'ng PE dan Lim TH. 2011. Some physical properties of Parkia speciosa seeds. Paper, International Conference on Food Engineering and Biotechnology (ICFEB 2011), Bangkok, Thailand, 28-29 Mai.

[ADB] Asian Development Bank. 2011. Accounting for Health Impacts of Climate Change. Kota Mandaluyong, Filipina: ADB.

Aldrian E dan Susanto RD. 2003. Identification of three dominant rainfall regions within Indonesia and their relationship to sea surface temperature. International Journal of Climatology 23(12):1435-52.

An SI dan Wang B. 2000. Interdecadal change of the structure of the ENSO mode and its impact on the ENSO frequency. Journal of Climate 13(12):2044-55.

Baker JT, Allen LH dan Boote KJ. 1992.

Temperature effects on rice at elevated $\mathrm{CO}_{2}$ concentration. Journal of Experimental Botany 43(7):959-64.

Barnabás B, Jäger K dan Fehér A. 2008. The effect of drought and heat stress on reproductive processes in cereals. Plant, Cell \& Environment 31(1):11-38.

Belcher B, Imang N dan Achdiawan R. 2004. Rattan, rubber, or oil palm: Cultural and financial considerations for farmers in Kalimantan. Economic Botany 58(1):77-87.

Bennett A, Epstein L, Gilman R, Cama V, Bern C, Cabrera L, dkk. 2012. Effects of the 1997-1998 El Niño episode on community rates of diarrhea. American Journal of Public Health 102(7):63-69.

Bhagwat S, Willis K, Birks HJ dan Whittaker R. 2008. Agroforestry: A refuge for tropical biodiversity? Trends in Ecology and Evolution 23(5):261-27.

Brown M. 1997. Durio, a Bibliographic Review. New Delhi: International Plant Genetic Resources Institute.

Budidarsono S, Laxman J dan Wibawa G. 2010. Profitability assessment of smallholder rubber agroforestry systems in Jambi, Sumatra, Indonesia. Project report. Bogor, Indonesia: World Agroforestry Centre.

Cairns JE, Sonder K, Zaidi PH, Verhulst N, Mahuku G, Babu R, Nair SK, Das B, Govaerts B,
Vinayan MT dkk. 2012. Maize production in a changing climate: Impacts, adaptation, and mitigation strategies. Advances in Agronomy 114:1-58.

Caplow S, Jagger P, Lawlor K dan Sills E. 2011. Evaluating land use and livelihood impact of early forest carbon projects: Lessons from learning about REDD+. Environmental Science and Policy 14:152-67.

Ceballos H, Ramirez J, Bellotti AC, Jarvis A dan Alvarez E. 2011. Adaptation of cassava to changing climates. Dalam Singh Yadav S, Redden R, Hatfield J, Lotze-Campen H dan Hall AJ, eds. Crop Adaptation to Climate Change. Wiley-Blackwell. 411-25.

Chaudhury A. 2012. Unlocking the Power of Local Knowledge: A Novel Framework to Cost Community-Based Adaptation to Climate Change. Oxford, Inggris: Environmental Change Institute, University of Oxford.

Checkley W, Epstein L, Gilman R, Figueroa D, CamaR, Patz J dan Black RE. 2000. Effect of El Niño and ambient temperature on hospital admissions for diarrhoeal diseases in Peruvian children. Lancet 355:442-50.

Cochrane MA dan Laurance WF. 2002. Fire as a large-scale edge effect in Amazonian forests. Journal of Tropical Ecology 18(03):311-25.

Cochrane MA dan Schulze MD. 1998. Forest fires in the Brazilian Amazon. Conservation Biology 12(5):948-50.

Cochrane MA, Alencar A, Schulze MD, Souza CM, Nepstad DC, Lefebvre P dan Davidson EA. 1999. Positive feedbacks in the fire dynamic of closed canopy tropical forests. Science 284(5421):1832-35.

Cronkleton P, Taylor PL, Barry D, StoneJovicich S dan Schmink M. 2008. Environmental governance and the emergence of forest-based social movements. Occasional Paper No. 49. Bogor, Indonesia: CIFOR.

Cruz RV, Harasawa H, Lal M, Wu S, Anokhin Y, Punsalmaa B, dkk. 2007. Asia. Dalam Parry ML, Canzianni OF, Palutikof JP, van der Linden PJ dan Hanson CE, eds. Climate Change 2007: Impacts, Adaptation and Vulnerability. Contribution of Working Group II to the Fourth 
Assessment Report of the Intergovernmental Panel on Climate Change. Cambridge, Inggris: Cambridge University Press. 469-506.

[DNPI and GoEK] National Council on Climate Change and Government of East Kalimantan. 2010. East Kalimantan environmentally sustainable development strategy (draf untuk diedarkan).

Ekanayake IJ, Datta SK dan Steponkus PL 1989. Spikelet sterility and flowering response of rice to water stress at anthesis. Annals of Botany 63(2):257-64.

[FAO] Food and Agriculture Organization of the United Nations. 2007. Durio zibethinus. Diakses 15 Juni 2013. http://ecocrop.fao.org/ecocrop/ srv/en/cropView?id=963

Field CB, Barros V, Stocker TF, Qin D, Dokken, DJ, Ebi KL dkk. 2012. Managing the Risks of Extreme Events and Disasters to Advance Climate Change Adaptation. A Special Report of Working Groups I and II of the Intergovernmental Panel on Climate Change. Intergovernmental Panel on Climate Change.

Fischlin A, Midgley GF, Price JT, Leemans R, Gopal B, Turley C, Rounsevell M, Dube P, Tarazona J dan Velichko AA. 2007. Ecosystems, their properties, goods, and services. Dalam Parry ML, Canziani OF, Palutikof JP, van der Linden PJ dan Hanson CE, eds. Climate Change 2007: Impacts, Adaptation and Vulnerability. Contribution of Working Group II to the Fourth Assessment Report of the Intergovernmental Panel on Climate Change. Cambridge: Cambridge University Press. 211-72.

Fisher M, Chaudhury M dan McCusker B. 2010.

Do forests help rural households adapt to climate variability? Evidence from southern Malawi. World Development 38(9):1241-50. doi:10.1016/j.worlddev.2010.03.005

Garrity DP, Akinnifesi FK, Ajayi OC, Weldesemayat SG, Mowo JG, Kalinganire A, Larwanou M dan Bayala J. 2010. Evergreen agriculture: A robust approach to sustainable food security in Africa. Food Security 2(3):197-214.

Gockowski J, Nkamleu G dan Wendt J. 2001. Implications of resource-use intensification for the environment and sustainable technology systems in the Central African rainforest. Dalam Lee D and Barrett C, eds. Tradeoffs or Synergies? Agricultural Intensification, Economic Development and the Environment. Wallingford, Inggris: $\mathrm{CAB}$ International.
Graham K. 2011. REDD+ and Adaptation: Will REDD + Contribute to Adaptive Capacity at the Local Level? London: Overseas Development Institute. Diakses 15 Juni 2013. http://www.odi. org.uk/publications/6147-redd-adaptation-localadaptive-capacity

Hadi T. 2010. Scientific Basis: Analysis and Projection of Temperature and Rainfall. Bappenas, Jakarta.

Hales S, de Wet N, Maindonald J dan Woodward A. 2002. Potential effect of population and climate changes on global distribution of dengue fever: An empirical model. Lancet 360(9336):830-34.

Hendon HH. 2003. Indonesian rainfall variability: Impacts of ENSO and local air-sea interaction. Journal of Climate 16(11):1775-90.

Herrera Campo B, Hyman G dan Bellotti A. 2011. Threats to cassava production: Known and potential geographic distribution of four key biotic constraints. Food Security 3(3):329-45.

Hijmans RJ, Cameron SE, Parra JL, Jones PG dan Jarvis A. 2005. Very high resolution interpolated climate surfaces for global land areas.

International Journal of Climatology 25:1965-78.

Hilman M, Boer R, Sulistyowati, Las L, Zed F, Masripatin N, Kartakusuma DA, Hilman D, Mulyanto HS dkk. 2010. Indonesia Second National Communication under the United Nations Framework Convention on Climate Change. Jakarta: Ministry of Environment.

[ICRAF] World Agroforestry Centre. 2013. Agroforestree database. Diakses 15 Juni 2013. http://www.worldagroforestrycentre.org/Sea/ Products/AFDbases/AF/index.asp

Ilahang, Wibawa G, Penot E dan Budi. 2006. Alternatif Pengembangan Karet Rakyat Dengan Sistem Wanatani Berbasis Karet. Bogor, Indonesia: World Agroforestry Centre.

[IRI] International Research Institute for Climate and Society. 2007. Overview of the ENSO system. Resources on El Niño and La Niña. Diakses 11 Februari 2013. http://iri.columbia. edu/climate/ENSO/background/pastevent.html

Iwan R dan Limberg G. 2009. Tane'Olen as an alternative for forest management: Further developments in Setulang village, East Kalimantan. Dalam Moeliono M, Wollenberg E dan Limberg G, eds. The Decentralization of Forest Governance: Politics, Economics and the Fight for Control of Forest in Indonesian Borneo. London: Earthscan. 193-202.

Iwan R dan Limberg G. 2009. Tane'Olen as an alternative for forest management: Further 
developments in Setulang village, East Kalimantan. Dalam Moeliono M, Wollenberg $\mathrm{L}$ dan Limberg G, eds. The Decentralization of Forest Governance: Politics, Economics and the Fight for Control of Forest in Indonesian Borneo. London: Earthscan. 193-202.

Iwan R. 2006. Tane Olen: A piece in the village landscape land use planning in Setulang Village, East Kalimantan. Presentation, 11th Conference of the International Association for the Study of Common Property, Bali, Indonesia.

Jarvis A, Ramirez-Villegas J, Herrera Campo B dan Navarro-Racines C. 2012. Is cassava the answer to African climate change adaptation? Tropical Plant Biology 5(1):9-29. doi:10.1007/s12042012-9096-7

Kates RW, Travis WR dan Wilbanks TJ. 2012. Transformational adaptation when incremental adaptations to climate change are insufficient. Proceedings of the National Academy of Sciences 109(19):1-6. doi:10.1073/pnas.1115521109

Keil A, Zeller M, Wida A, Sanim B dan Birner R. 2008. What determines farmers' resilience towards ENSO-related drought? An empirical assessment in Central Sulawesi, Indonesia. Climatic Change 86(3-4):291-307.

Kinnaird MF dan O'BrienTG. 1998. Ecological effects of wildfire on lowland rainforest in Sumatra. Conservation Biology 12(5):954-56.

Lansigan F, de los Santos W dan Coladilla J. 2000. Agronomic impacts of climate variability on rice production in the Philippines. Agriculture, Ecosystems \& Environment 82(1-3): 129-37.

Larson A. 2011. Forest tenure reform in the age of climate change: Lessons for REDD+. Global Environmental Change 21(2):540-49.

Lebot V. 2009. Tropical Root and Tuber CropsCassava, Sweet Potato, Yams and Aroids. Crop Production Science in Horticulture, 17. CABI, London.

Leimona B dan Joshi L. 2010. Eco-certified natural rubber from sustainable rubber agroforestry in Sumatra, Indonesia. Final project report. Bogor, Indonesia: World Agroforestry Centre.

Levang P dan FPP-Bulungan team. 2002. People's dependencies on forests.InTechnical report phase I 1997-2001: ITTO Project PD 12/97 REV.1 (F): Forest, science and sustainability: The Bulungan model forest. Bogor, Indonesia: CIFOR and ITTO. 109-30. Diakses 15 Juni 2013. http:// www.cifor.org/online-library/browse/viewpublication/publication/1181.html
Lin BB, Perfecto I dan Vandermeer J. 2008. Synergies between agricultural intensification and climate change could create surprising vulnerabilities for crops. Bioscience 58:847-54.

Lin BB. 2007. Agroforestry management as an adaptive strategy against potential microclimate extremes in coffee agriculture. Agricultural and Forest Meteorology 144(1):85-94.

Lin BB. 2010. The role of agroforestry in reducing water loss through soil evaporation and crop transpiration in coffee agroecosystems. Agricultural and Forest Meteorology 150(4):510-18.

Liswanti N, Sheil D, Basuki I, Padmanaba M dan Mulcahy G. 2011. Falling back on forests: How forest-dwelling people cope with catastrophe in a changing landscape. International Forestry Review 13(4):442-55.

Liswanti N, Sheil D, Basuki I, Padmanaba M dan Mulcahy G. 2011. Falling back on forests: How forest-dwelling people cope with catastrophe in a changing landscape. International Forestry Review (4 SP 442-55).

Lobell DB, Banziger M, Magorokosho C dan Vivek B. 2011. Nonlinear heat effects on African maize as evidenced by historical yield trials. Nature Climate Change 1(1):42-45.

Locatelli B, Evans V, Wardell A, Andrade A dan Vignola R. 2011. Forests and climate change in Latin America: Linking adaptation and mitigation. Forests 2(1):431-50.

Locatelli B. 2011. Synergies between Adaptation and Mitigation in a Nutshell. Bogor, Indonesia: Center for International Forestry Research.

Masozera M dan Alavalapati JR. 2004. Forest dependency and its implications for protected areas management: A case study from the Nyungwe Forest Reserve, Rwanda. Scandinavian Journal of Forest Research 19:85-92.

McSweeney K. 2005. Natural insurance, forest access and compounded misfortune: Forest resources in smallholder coping strategies before and after Hurricane Mitch, northeastern Honduras. World Development 33(9):1453-71.

Mitchell T dan Maxwell S. 2010. Defining Climate Compatible Development. London: Climate and Development Knowledge Network.

Mitchell TD and Jones PD. 2005. An improved method of constructing a database of monthly climate observations and associated highresolution grids. International Journal of Climatology 25:693-712. 
Mitchell TD, Carter TR, Jones PD, Hulme M dan New M. 2004. A comprehensive set of highresolution grids of monthly climate for Europe and the globe: The observed record (1901-2000) and 16 scenarios 2001-2100. Norwich, Inggris: Tyndall Centre for Climate Change Research.

Moeliono M dan Limberg G. 2009. The geography of Malinau. Dalam Moeliono M, Wollenberg E dan Limberg G, eds. The Decentralization of Forest Governance: Politics, Economics and the Fight for Control of Forest in Indonesian Borneo. London: Earthscan. 25-42.

Moeliono M, Limberg G, Gonner C, Wollenberg E dan Iwan R. 2007. Towards Wellbeing: Monitoring Poverty in Malinau, Indonesia. Bogor, Indonesia: CIFOR.

Moeliono M, Wollenberg E dan Limberg G, eds. 2009. The Decentralization of Forest Governance: Politics, Economics and the Fight for Control of Forest in Indonesian Borneo. London: Earthscan.

Morton J. 1987. Fruits of Warm Climates. Miami: Florida Flair Books.

Murniati, Garrity D dan Gintings A. 2001. The contribution of agroforestry systems to reducing farmers' dependence on the resources of adjacent national parks: A case study from Sumatra, Indonesia. Agroforestry Systems 52(3):171-84.

Nguyen NV. n.d. Global Climate Changes and Rice Food Security. Roma: Food and Agriculture Organization of the United Nations.

Nicholls J, Lawlor E, Neitzert E dan Goodspeed T. 2012. A Guide to Social Return on Investment. SROI Network. http://www.thesroinetwork.org/ sroi-analysis/the-sroi-guide

O'Toole JC dan Namuco OS. 1983. Role of panicle exsertion in water stress induced sterility. Crop Science 23(6):1093-97.

Pambudhi F, Belcher B, Levang P dan Dewi S. 2004. Rattan (Calamus spp.) gardens of Kalimantan: Resilience and evolution in a managed nontimber forest product system. Dalam Kuster K dan Belcher B, eds. Forest Products, Livelihoods and Conservation: Case Studies of Non-Timber Forest Product Systems. Bogor, Indonesia: CIFOR. 347-65.

Pandey S, Bhandari H dan Hardy B. 2004. Economic Costs of Drought and Rice Farmers' Coping Mechanisms: A Cross-Country Comparative Analysis. Manila: International Rice Research Institute.

Parker D. 2013. Indonesia's East Kalimantan loses forest area to new province in Borneo. Mongabay.com. http://news.mongabay. com/2013/0224-dparker-north-kalimantan. html. Diakses 10 Mei 2013.

Peng S, Huang J, Sheehy JE, Laza RC, Visperas RM, Zhong X, dkk. 2004. Rice yields decline with higher night temperature from global warming. Proceedings of the National Academy of Sciences 101(27):9971-75.

Peramune M dan Afs D. 2007. A Value Chain Assessment of the Rubber Industry in Indonesia. Jakarta: United States Agency for International Development.

Peskett L, Huberman D, Bowen-Jones E, Edwards G dan Brown J. 2008. Making REDD Work for the Poor. London: Poverty Environment Partnership.

Peterson TC, Stott PA dan Herring S. 2012. Explaining extreme events of 2011 from a climate perspective. Bulletin of the American Meteorological Society 93(7):1041-67.

Plummer R dan Armitage D. 2010. Integrating perspectives on adaptive capacity and environmental governance. Dalam Plummer $\mathrm{R}$ dan Armitage D, eds. Adaptive Capacity and Environmental Governance. Berlin: SpringerVerlag. 1-22.

Pramova E, Locatelli B, Djoudi H dan Somorin OA. 2012. Forests and trees for social adaptation to climate variability and change. Wiley Interdisciplinary Reviews: Climate Change 3(6):581-96.

Purnama BM, Prahastó H dan Nasendi BD. 1998. Rattan in East and South Kalimantan, Indonesia: A case study of the production-to-consumption systems. INBAR Working Paper No. 21. New Delhi: International Network for Bamboo and Rattan.

Rahmad 2011. Kebutuhan Pupuk Kaltim Capai 67.723 Ton. Antaranews.com, Kalimantan Timur. http://www.antarakaltim.com/ berita/4228/kebutuhan-pupuk-kaltim-capai67723-ton Diakses: 10 Mei 2013

Rai Y, Ale B dan Alam J. 2012. Impact assessment of climate change on paddy yield: A case study of Nepal Agriculture Research Council (NARC), Tarahara, Nepal. Journal of the Institute of Engineering 8(3):147-67.

Roberts SJ. 2000. Tropical fire ecology. Progress in Physical Geography 24(2):281-88.

Rodrigo VH, Iqbal SM dan Dharmakeerthi R. 2011. Potential for rubber (Hevea brasiliensis Muell. Arg.) cultivation in the Eastern Province of Sri Lanka. Journal of the National Science Foundation of Sri Lanka 39(4):403-11. 
Ruf F dan Lançon F. 2004. From Slash and Burn to Replanting: Green Revolutions in the Indonesian Uplands. Washington, DC: World Bank.

Sastry PS. 1988. Agrometeorology of the Banana Crop. Geneva: World Meteorological Organization.

Schroth G, Da Fonseca GA, Harvey C, Gascon C, Vasconcelos HL dan Izac AM. 2004. Agroforestry and Biodiversity Conservation in Tropical Landscapes. Washington, DC: Island Press.

Schwendenmann L, Veldkamp E, Moser G, Hölscher D, Köhler M, Clough, Y, Anas I, Djajakirana G, Erasmi S, Hertel D dkk. 2010. Effects of an experimental drought on the functioning of a cacao agroforestry system, Sulawesi, Indonesia. Global Change Biology 16(5):1515-30.

Sdoodee S dan Rongsawat S. 2012. Impact of climate change on smallholders' rubber production in Songkhla Province, Southern Thailand. Presentation, 2012 International and National Conference for the Sustainable Community Development of "Local Community: The Foundation of Development in the ASEAN Economic Community (AEC)," Khon Kaen, Thailand.

Sheil D, van Heist M, Liswanti N, Basuki I dan Wan M. 2009. Biodiversity, landscapes and livelihoods: A local perspective. Dalam Moeliono M, Wollenberg E dan Limberg G, eds. 2009. The Decentralization of Forest Governance: Politics, Economics and the Fight for Control of Forest in Indonesian Borneo. London: Earthscan. 25-42.

Sheil, D. 2002. Biodiversity research in Malinau. Dalam Technical report phase I 1997-2001: ITTO Project PD 12/97 REV.1 (F): Forest, science and sustainability: The Bulungan model forest. Bogor, Indonesia: CIFOR and ITTO. 57-107. Diakses 15 Juni 2013. http://www.cifor. org/online-library/browse/view-publication/ publication/1181.html

Sidiyasa K, Zakaria dan Iwan R. 2006. The forests of Setulang and Sengayan in Malinau, East Kalimantan: Their potential and the identification of steps for their protection and sustainable management. Bogor, Indonesia: CIFOR.

Smit B dan Pilifosova O. 2001. Adaptation to climate change in the context of sustainable development and equity. Dalam McCarthy JJ, Canzianni OF, Leary NA, Dokken DJ dan White KS, eds. Impacts, Adaptation, and VulnerabilityContribution of Working Group II to the Third Assessment Report of the Intergovernmental Panel on Climate Change. Cambridge, Inggris: Cambridge University Press. 876-912.
Sofian I. 2010. Scientific Basis: Analysis and Projection of Sea Level Rise and Extreme Weather Event. Bappenas, Jakarta.

Sova C, Chaudhury A, Helfgott A dan CornerDolloff C. 2012. Community-based adaptation costing: An integrated framework for the participatory costing of community-based adaptations to climate change in agriculture. Working paper No. 16. Cali, Colombia: CGIAR Research Program on Climate Change, Agriculture and Food Security. Diakses 15 Juni 2013. http://ccafs.cgiar.org/sites/default/files/ assets/docs/ccafs-wp-16-psroi.pdf

Spearman M dan McGray H. 2011. Making Adaptation Count: Concepts and Options for Monitoring and Evaluation of Climate Change Adaptation. Eschborn, Germany: Deutsche Gesellschaft für Internationale Zusammenarbeit.

Steffan-Dewenter I, Kessler M, Barkmann J, Bos MM, Buchori D, Erasmi S, Faust H, Gerold G, Glenk K, Gradstein SR dkk. 2007. Tradeoffs between income, biodiversity and ecosystem functioning during tropical rainforest conversion and agroforestry intensification. Proceedings of the National Academy of Sciences of the USA 104:4973-78.

Subhadrabandhu S. 2001. Under-utilized tropical fruits of Thailand.RAP Publication No. 2001/26. Bangkok: Food and Agriculture Organization of the United Nations.

Sudana M. 2009. Winners take all: Understanding forest conflict in the era of decentralization in Indonesia. Dalam Moeliono M, Wollenberg E and Limberg G, eds. 2009. The Decentralization of Forest Governance: Politics, Economics and the Fight for Control of Forest in Indonesian Borneo. London: Earthscan. 207-219.

Sunderlin W, Larson A dan Cronkleton P. 2009. Forest tenure rights and REDD+: From inertia to policy solutions. Dalam Angelsen A, ed. Realising REDD+: National Strategies and Policy Options. Bogor, Indonesia: CIFOR.

Susanti E, Ramadhani F, June T dan Amien L. 2010. Utilization of climate information for development of early warning system for brown plant hopper attack on rice. Indonesian Journal of Agriculture 3(1):17-25.

Timmermann A. 2001. Changes of Enso stability due to greenhouse warming. Geophysical Research Letters 28(10):2061-64.

Tindall HD 1994. Rambutan cultivation. Rome: Food and Agriculture Organization of the United Nations. 
Turner D dan Lahav E. 1983. The growth of banana plants in relation to temperature. Functional Plant Biology 10(1):43-53.

Van Nieuwstadt MGL dan Sheil D. 2005. Drought, fire and tree survival in a Borneo rain forest, East Kalimantan, Indonesia. Journal of Ecology 93(1):191-201. doi:10.1111/j.13652745.2004.00954.x

Van Vliet N, Mertz O, Heinimann A, Langanke T, Pascual U, Schmook B, Adams C, Schmidt-Vogt D, Messerli P, Leisz S dkk. 2012. Trends, drivers and impacts of changes in swidden cultivation in tropical forest-agriculture frontiers: A global assessment. Global Environmental Change 22(2):418-29.

Verchot L, Van Noordwijk M, Kandji S, Tomich T, Ong C, Albrecht A, Mackensen J, Bantilan C, Anupama KV dan Palm C. 2007. Climate change: linking adaptation and mitigation through agroforestry. Mitigation and Adaptation Strategies for Global Change 12(5):901-18.

Verchot L, Van Noordwijk M, Kandji S, Tomich T, Ong C, Albrecht A, dkk. 2007. Climate change: Linking adaptation and mitigation through agroforestry. Mitigation and Adaptation Strategies for Global Change 12(5):901-918. doi:10.1007/ s11027-007-9105-6

Wassmann R, Jagadish SV, Heuer S, Ismail A, Redona E, Serraj R, dkk. 2009. Climate Change Affecting Rice Production: The Physiological and Agronomic Basis for Possible Adaptation Strategies. Dalam Sparks D, ed. Advances in Agronomy. Vol. 101. Elsevier. 59-122.

Wulan YC, Budidarsono S dan Joshi L. 2008. Economic analysis of improved smallholder rubber agroforestry systems in West Kalimantan, Indonesia-implications for rubber development.
Presentation, Sustainable Sloping Lands and Watershed Management Conference, Luang Prabang, Lao PDR.

Wunder S, Campbell B, Frost PG, Sayer JA, Iwan R dan Wollenberg L. 2008. When donors get cold feet: The community conservation concession in Setulang (Kalimantan, Indonesia) that never happened. Ecology and Society 13(1):12. http:// www.ecologyandsociety.org/vol13/iss 1/art12/

Yeh SW, Kug JS, Dewitte B, Kwon MH, Kirtman BP dan Jin FF. 2009. El Niño in a changing climate. Nature 461(7263):511-514. doi:10.1038/ nature 08316

Yoshida, S. 1978. Tropical climate and its influence on rice. IRRI Research Paper Series 20. Los Baños, Filipina

Zaidi P dan Singh N. 2001. Effect of water logging on growth, biochemical compositions and reproduction in maize (Zea mays L.).Journal of Plant Biology-New Delhi 28(1):61-70.

Zaidi PH, Rafique $S$ dan Singh N. 2003. Response of maize (Zea mays L.) genotypes to excess soil moisture stress: Morpho-physiological effects and basis of tolerance. European Journal of Agronomy 19(3):383-99.

Zuidema PA, Leffelaar PA, Gerritsma W, Mommer L dan Anten NP. 2005. A physiological production model for cocoa (Theobroma cacao): Model presentation, validation and application. Agricultural Systems 84(2):195-225.

Zuidema PA, Leffelaar PA, Gerritsma W, Mommer L dan Anten NP. 2005. A physiological production model for cocoa (Theobroma cacao): Model presentation, validation and application. Agricultural Systems 84(2):195-225. 


\section{Lampiran}

\section{Lampiran 1. Jadwal kegiatan}

Berdasarkan tujuan yang telah ditetapkan, sejumlah kegiatan di bawah ini dilaksanakan mulai Februari sampai dengan September 2012 untuk kedua lokasi di Indonesia dan Filipina.

\begin{tabular}{ll}
\hline Kerangka waktu (2012) & Kegiatan \\
\hline Februari & Analisis desktop atas informasi yang dipublikasikan terkait lokasi-lokasi proyek REDD+ GIZ \\
Februari & Daftar periksa (checklist) dibuat untuk pemilihan lokasi dan dikirim pada tim proyek \\
& REDD+ GIZ terpilih \\
Maret & Pemilihan lokasi berdasarkan komunikasi dengan tim proyek dan informasi pendahuluan \\
Maret-April & Penjabaran rencana kegiatan secara terperinci untuk lokakarya dan diskusi dengan mitra \\
& kegiatan serta tanggal yang sesuai \\
April-Juni & Studi desktop dan pemodelan iklim untuk lokasi di Indonesia \\
22-23 Juni & Lokakarya masyarakat (Indonesia) \\
Juli & Sintesis hasil studi desktop untuk presentasi tingkat kabupaten (Indonesia) \\
Juli-September & Studi desktop dan pemodelan iklim untuk lokasi di Filipina, sintesis hasil untuk presentasi \\
& lokakarya tingkat provinsi \\
3-4 September & Lokakarya masyarakat (Filipina) \\
13 September & Lokakarya tingkat provinsi (Filipina) \\
$10-20$ September & Wawancara semiterstruktur dengan pemangku kepentingan tingkat kabupaten \\
& (Indonesia) dan kunjungan ke Setulang \\
\hline
\end{tabular}




\section{Lampiran 2. Panduan untuk wawancara semiterstruktur dengan pemangku kepentingan kabupaten}

\section{Bencana, dampak dan tantangan iklim}

\begin{tabular}{l} 
Pertanyaan utama \\
\hline Dapatkah anda menceritakan tentang bencana \\
iklim yang memengaruhi Malinau dan/atau \\
wilayah kerja anda?
\end{tabular}

Dari pengalaman anda, bencana iklim apakah yang paling menggangu masyarakat?

\section{ATAU}

Menurut pendapat anda, apakah masalah iklim yang paling mengkhawatirkan di wilayah anda?

Apakah tantangan penting lain (tidak terkait iklim) di wilayah anda?

\section{ATAU}

Menurut pendapat anda, apa sajakah masalah penting di wilayah ini?

Menurut anda, bagaimana tantangan tersebut (baik yang terkait iklim maupun tidak) akan berkembang di masa depan apabila tidak dilakukan tindakan apapun?

Diskusi tentang bahaya dan tantangan utama yang dihadapi masyarakat Setulang.

Di Setulang masyarakat menganggap 5 hal ini sebagai tantangan yang paling penting:

Konflik sosial terkait tenurial (dengan desa dan konsesi yang bersebelahan)

Obat-obatan (penyalahgunaan oleh kaum muda)

Penyalahgunaan kekuasaan politik

Polusi sungai

Banjir

Pertanyaan dan pengamatan Pertanyaan klarifikasi
tambahan

Apa dampak yang disebabkan oleh bencana ini?

Dapatkah anda menjelaskan lebih jauh soal ini?

Apakah pengaruh dari dampak ini? Tempat-tempat mana yang paling terpengaruh dan kapan?

Siapa yang paling terpengaruh dan Apakah ada hal-hal lain yang bisa anda ceritakan Dapatkah anda memberikan beberapa contoh?
Dalam situasi yang bagaimanakah masalah serius akan muncul?

Apakah anda melihat adanya perubahan situasi selama beberapa tahun ini?

Mengapa?

Mengapa masalah ini terjadi? Apa pengaruh dari masalah ini? Siapa yang paling terpengaruh dan mengapa?

Apakah anda mengamati adanya perubahan situasi dari tahun ke tahun?

Siapa yang akan terpengaruh, bagaimana dan mengapa?

Bagaimana tantangan tersebut akan berdampak pada pengelolaan hutan, khususnya terkait dengan wilayah kerja anda?

Apa pendapat anda atas isu-isu ini? Apa kaitan antara tantangantantangan ini dengan yang kita diskusikan sebelumnya? 
Lampiran 2 (lanjutan)

\begin{tabular}{|c|c|c|}
\hline \multicolumn{3}{|l|}{ Sumber daya dan strategi } \\
\hline Pertanyaan utama & $\begin{array}{l}\text { Pertanyaan dan pengamatan } \\
\text { tambahan }\end{array}$ & Pertanyaan klarfikasi \\
\hline \multirow{4}{*}{$\begin{array}{l}\text { Apa saja aset dan sumber daya yang } \\
\text { saat ini tersedia yang dapat membantu } \\
\text { mengelola tantangan yang dibahas } \\
\text { sebelumnya? }\end{array}$} & \multirow{2}{*}{$\begin{array}{l}\text { Terkait dengan aset/sumber daya dan } \\
\text { strategi khusus yang akan disebutkan } \\
\text { oleh responden }\end{array}$} & $\begin{array}{l}\text { Dapatkah anda menjelaskan } \\
\text { lebih jauh soal ini? }\end{array}$ \\
\hline & & Adakah hal-hal lain yang bisa \\
\hline & \multirow{2}{*}{$\begin{array}{l}\text { Bagaimana aset/sumber daya ini akan } \\
\text { digunakan? }\end{array}$} & Anda ceritakan? \\
\hline & & Dapatkah anda memberikan \\
\hline \multirow{2}{*}{$\begin{array}{l}\text { Apa sajakah sumber daya lain yang } \\
\text { menurut anda dibutuhkan? }\end{array}$} & Apa manfaat melakukan hal ini? & beberapa contoh? \\
\hline & $\begin{array}{l}\text { Kelompok target mana yang akan } \\
\text { merasakan manfaat? }\end{array}$ & \\
\hline $\begin{array}{l}\text { Dalam pendapat anda, bagaimana } \\
\text { kegiatan-kegiatan proyek Hutan Desa } \\
\text { dan REDD akan membantu masyarakat } \\
\text { Setulang menghadapi tantangan iklim } \\
\text { dan noniklim? }\end{array}$ & $\begin{array}{l}\text { Apa kaitan antara kegiatan dan aset/ } \\
\text { sumber daya ini dengan yang kita } \\
\text { diskusikan sebelumnya (jika ada)? }\end{array}$ & \\
\hline \multirow{2}{*}{$\begin{array}{l}\text { Pembahasan dan pertanyaan terkait } \\
\text { dua strategi adaptasi utama yang } \\
\text { diusulkan oleh masyarakat di Setulang, } \\
\text { yang dipilih untuk analisis lebih lanjut. }\end{array}$} & \multicolumn{2}{|l|}{ Untuk masing-masing strategi: } \\
\hline & \multicolumn{2}{|l|}{$\begin{array}{l}\text { Manfaat dan biaya yang mana, dari } \\
\text { yang anda sebutkan, yang anda anggap } \\
\text { paling penting dan mengapa? }\end{array}$} \\
\hline $\begin{array}{l}\text { Beberapa informasi indikatif terkait } \\
\text { strateai dari penaalaman di tempat lain }\end{array}$ & \multicolumn{2}{|l|}{$\begin{array}{l}\text { Apakah dampak positif dan negatif } \\
\text { yang dapat terjadi dari strategi ini }\end{array}$} \\
\hline \multirow{2}{*}{$\begin{array}{l}\text { Kebun wanatani karet (pohon karet } \\
\text { ditumpangsarikan dengan padi pada } \\
\text { tahun pertama, dan dengan jenis } \\
\text { pohon buah-buahan): }\end{array}$} & $\begin{array}{l}\text { (untuk jenis kelompok yang berbeda - } \\
\text { misalnya perempuan dan kaum muda)? }\end{array}$ & \\
\hline & \multicolumn{2}{|l|}{$\begin{array}{l}\text { Bagaimana anda melihat implementasi } \\
\text { dari strategi ini? }\end{array}$} \\
\hline $\begin{array}{l}\text { Menurut anda, apakah manfaat dari } \\
\text { strategi ini? }\end{array}$ & \multicolumn{2}{|l|}{$\begin{array}{l}\text { Bagaimana ini akan berdampak pada } \\
\text { wilayah kerja anda? }\end{array}$} \\
\hline $\begin{array}{l}\text { Apakah biaya dan/atau hambatan yang } \\
\text { terkait? }\end{array}$ & \multicolumn{2}{|l|}{$\begin{array}{l}\text { Apakah dampak strategi ini bagi } \\
\text { pengelolaan hutan? }\end{array}$} \\
\hline $\begin{array}{l}\text { Pemanfaatan yang meningkat atas } \\
\text { hasil-hasil hutan bukan kayu (misalnya, } \\
\text { rotan) untuk kerajinan tangan, dan } \\
\text { pemasaran kerajinan tangan ini: }\end{array}$ & \multicolumn{2}{|l|}{$\begin{array}{l}\text { Apakah dampak strategi ini pada } \\
\text { sasaran proyek REDD+? }\end{array}$} \\
\hline \multicolumn{3}{|l|}{$\begin{array}{l}\text { Menurut anda, apakah manfaat dari } \\
\text { strategi ini? }\end{array}$} \\
\hline $\begin{array}{l}\text { Apakah biaya dan/atau hambatan yang } \\
\text { terkait? }\end{array}$ & & \\
\hline
\end{tabular}

Kesimpulan wawancara

Apakah ada hal-hal penting lain yang ingin anda tekankan?

ATAU

Adakah hal-hal yang ingin anda tambahkan untuk diskusi ini atau untuk studi kami? 


Makalah Kerja CIFOR menyajikan berbagai hasil penelitian yang sedang berlangsung tentang berbagai isu hutan tropis yang perlu segera diterbitkan untuk membagikan informasi atau mendukung pengambilan keputusan. Isi makalah sudah dikaji secara internal tetapi belum dikaji secara eksternal oleh penelaah sejawat.

Intervensi REDD+ dapat membantu masyarakat dan hutan untuk beradaptasi dengan perubahan iklim melalui melestarikan dan menguatkan jasa keanekaragaman hayati dan ekosistem hutan. Namun, sejumlah tindakan adaptasi tambahan mungkin diperlukan, seperti perlindungan bagi pertanian dan penghidupan serta pengembangan sejumlah strategi pengelolaan kebakaran. Berbagai tindakan ini dapat mendukung keberlanjutan intervensi REDD+ dan kepermanenan cadangan karbon dengan mencegah kegiatan yang merugikan dan memicu deforestasi serta dengan membatasi atau menghindari kerusakan ekosistem dari kejadian iklim ekstrem.

Untuk merancang intervensi adaptasi berbasiskan masyarakat dan mengukur keluaran potensialnya pada Hutan Desa dalam wilayah proyek REDD+ di Desa Setulang, Kabupaten Malinau, Kalimantan, para perwakilan desa dilibatkan dalam suatu proses partisipatif, yang berfokus pada para pemangku kepentingan. Suatu kerangka kerja rentabilitas sosial diterapkan. Para anggota masyarakat mendiskusikan berbagai tantangan iklim maupun noniklim dan sejauh mana keefektifan strategi mereka saat ini dalam menghadapinya. Intervensi adaptasi kemudian disusun dan direncanakan, dengan menggunakan latihan-latihan melihat ke masa depan (visioning). Dua intervensi dijadikan prioritas: pengembangan usaha kerajinan tangan rotan dan wanatani karet.

Berbagai tantangan dan adaptasi dari intervensi juga dibahas dengan para pemangku kepentingan dari organisasi tingkat kabupaten yang bersangkutan (misalnya, dinas pemerintah setempat) melalui wawancara semiterstruktur secara perorangan. Prakiraan skenario masa depan, sensitivitas sumber daya utama dan kapasitas adaptif juga didiskusikan. Proses ini menghasilkan sebuah pemahaman yang menyeluruh tentang biaya, manfaat, peluang dan tantangan yang berkaitan dengan implementasi sejumlah strategi adaptasi yang terpilih, tidak hanya di wilayah yang ditargetkan, namun juga secara lebih luas di wilayah kabupaten.

Proyek Hutan Desa di Setulang, Malinau ini difasilitasi oleh program FORCLIME oleh Deutsche Gesellschaft für Internationale Zusammenarbeit (GIZ GmbH). Studi ini dilaksanakan oleh CIFOR bekerja sama dengan GIZ, dengan hibah dari Kementerian Federal untuk Kerja sama Ekonomi dan Pembangunan (BMZ) Jerman.

\section{PROGRAM PENELITIAN PADA Hutan, Pohon dan Wanatani}

Penelitian ini dilaksanakan oleh CIFOR sebagai bagian dari Program Penelitian CGIAR pada Hutan, Pohon dan Wanatani (CRP-FTA). Program kolaboratif ini bertujuan untuk meningkatkan pengelolaan dan pemanfaatan hutan, wanatani, dan sumber daya genetis pohon yang mencakup lanskap dari hutan sampai ke lahan budidaya. CIFOR memimpin CRP-FTA melalui kemitraan dengan Bioversity International, CIRAD, International Center for Tropical Agriculture dan World Agroforestry Centre. 